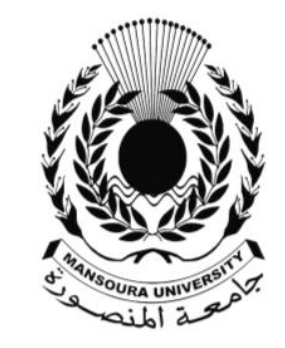

جامعة المنصـورة الماندة

كليـة الآداب

-

\title{
ارتباط الصيغة الصرفية بالمعنى في شعر طفيل الغنوي هقاربة لسانية تداولية
}

\author{
إعـــداد \\ دكتور / إبراهيم سند إبراهيم أحمد الشيخ \\ مدرس النحو والصرف والعروض \\ كلية دار العلوم- جامعة المنيا
}

مجـلة كلــية الآداب - جـامعـة المنصــورة

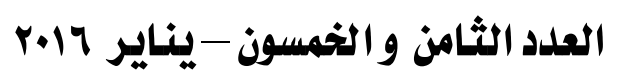




\section{ارتباطالصيغة الصرفية بالمعنـ في شعر طفيل الغنويي \\ مقاربة لسانية تداولية}

\section{د/ إبراهيم سندل إبراهيه أحمد الشيخ}

الدراسة الكثفَ عن ارتباط الصيغة الصرفية

$$
\text { بالمعنى في ضوء التداولية. }
$$

وتقوم الفكرة الرئيسة للبحث حول ارتباط

الصيخة الصرفية بالمعنى المتداول بين الشاعر

و المتلقي؛ ليبين كيف راعى الصرفيون تداول

المعنى في بناء الصيخ الصرفية، وكيف نجح

الثاعر في تحقيق التواصل مع المتلقي من خلا

الصيغ الصرفية، وكيف استطاعت التداولية

بأدو اتها المختلفة إبرازَ هذا التو اصل بين الشاعر

\section{Abstract}

$$
\text { و المتلقي. }
$$

This article tackles the relation between meaning and morphological forms in light of pragmatics which is concerned with language use, under the title:

"Relation between Morphological Forms and Meaning in the Poetry of Tufail Alghanawy: A Pragmatic Linguistic Approach".

The article firstly discusses the following terms: morphological form, meaning, and pragmatics. Then it deals with the communicative function of the ecart phenomenon, multiple morphological forms of one meaning, and multiple meanings of a morphological form focusing on the pragmatic elements.

The article studies four aspects: deixis, presupposition, conversational implicature, and speech acts. The morphological forms of the language use (textual structure of a poem) are not static templates, but they are language utterances spoken by the poet to express his intention to be delivered to the recipient in a linguistic
يعالج هذا البحثُ العلاقةَ بين المعنى و الصيغة الصرفية في ضوء التداولية التي تُعنَى بالاستعمال اللغوي تحث عنوان: (ارتباط الصيغة الصرفية بالمعنى في شعر طفيل الغنوي مقاربة

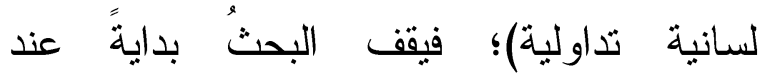
المصطلحات التالية: (الصيغة الصرفية، المعنى، التداولية)، ثم يُعرِج على الوظيفة التو اصلية في ظاهرة العدول، وتعدد الصيغ الصرفية للمعنى لتعزي الواحد، وتعدد المعنى في الصيغة الصرفية الواحدة في ضوء العناصر التداولية التالية:

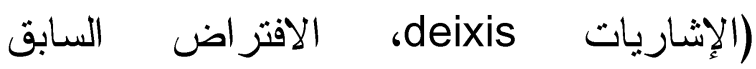
presupposition conversational Implicature الإنجازية (illocutionary acts). و الصيغ الصرفية في الاستعمال اللغوي (البناء النصي للقصيدة) ليست قو الب جامدة، و إنما هي منطوقات لغوية ينطق بها الثاعر للتعبيز عن قصده لإيصاله إلى المتلقي في إطارٍ لغوي تكشفه عناصر التداولية، والمستوى الصرفي باختلاف صيخه وأبنيته يعد مدخلً

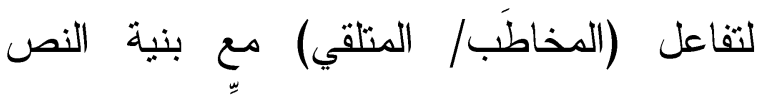
الشعري وفق عناصر تداولية تركِّ على المعنى ليّى المقصود، وانطلاقًا من هذه العناصر تحاول 
ذلك في تشكيل البناء الشعري عند طفيل الغنوي؛ وذلك بالتركيز على العلاقة القائمة بين طرفي الخطاب باعتبار هما أحد مبادئ التداولية، كما تهدف الدراسة إلى إبراز دور الصيغة الصرفية في تحقيق التواصل بين المتكلم و المخاطب، وبيان وجوه التقارب بين ما في التراث الصرفي وما جاءت به الدراسة التداولية في الدرس اللغوي المعاصر ·

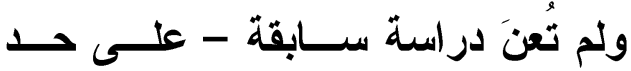

اطلاع الباحث - بموضوع: (ارتبـــاط الصـــيغة الصرفية بالمعنى في شعر طفيل الغنوي مقاربة لسانية تداولية)، و إن كانت هناك بعض الدر اسات السابقة التي اهتمت بالتداولية(1). ودراسات أخرى تتاولت شــعر طفبــل الغنوي(r)، أو تناولت قصائد بعينها من ديو انه(r)،

(') من هذه الار اسات على سبيل المثال ما يلي: • التداولية عند العلماء العرب دراسة تداولية لظاهرة

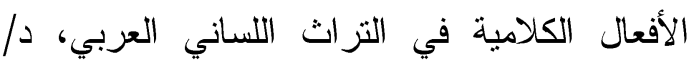

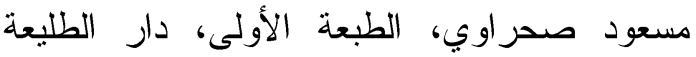

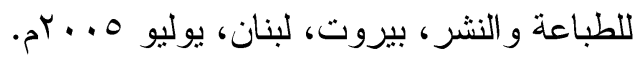

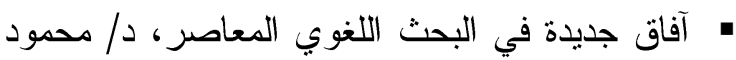
أحمد نحلة، الطبعة الأولى، الناشر: مكتبة الآداب،

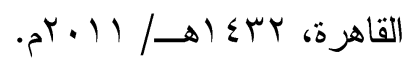

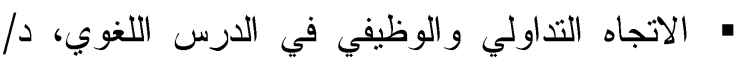
نادية رمضان النجار، الطبعة الأولى، مؤسسة

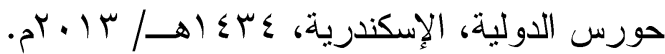
(r) من هذه الار اسات ما بليلي:

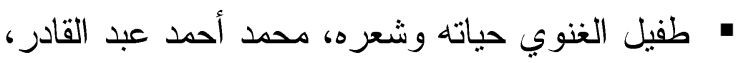
رسالة ماجستير، كلية الآداب، جامعة القاهرة، 970 frame revealed through the Pragmatic elements.

The morphological level with its variable forms and structures is a gateway to the reaction of the addressee/ recipient to the structure of the poetic text according to Pragmatic principles concerned with the intended meaning. on the basis of these principles, the study attempts to detect the correlation between morphological forms and meaning in accordance with Pragmatics.

The main idea of the article is the relation of morphological form to meaning circulated between the poet and the recipient to show how morphologists consider contextual meaning in structuring morphological forms, how the poet succeeded in communicating with the recipient through such morphological forms, and how pragmatics with its variable tools is able to highlight such communication between the poet and the recipient.

\section{المقدمــة}

الحمد لله رب العالمين الذي أنزل الكتاب

بلسان عربي مبين، والصدلاة والسلام على أشرف المرسلين وخاتم الأنبياء و وعلى آلهِ و أصحابِِ أجمعين، وبعد؛ ...

\section{فهذه الاراسة تتناول موضوع: (ارتباط}

الصيغة الصرفية بالمعنى في شعر طفيل الغنوي مقاربة لسانية تداولية)؛ ولعل الناظر في كتب الصرفيين يُركك مدى ارتباط الصيغة الصرفية بالمعنى، حيث تؤدي الصيغ الصرفية دورًا بارزًا في تشكيل بؤرة النص اللغوي؛ ولذلك ربط الصرفيون بين اللفظ ودلالته من خلال الصيغة

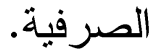

وتهدف هذه الاراسة إلى بيان مدى

ارتباط الصيغة الصرفية بالمعنى انطلاقاً من واقع الاستعمال التذاولي في لغة الخطاب، و أثز 
ومن ثم فإنَّ الموضوع - من وجهة نظر الباحث

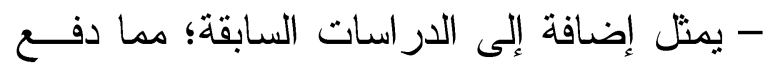
الباحث إلى العناية بدر اسة الموضوع.

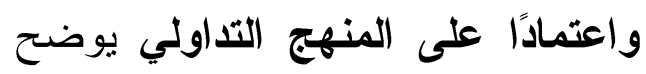

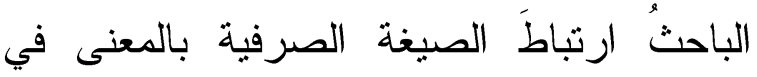
ضوء عناصر التداولية: (الإشاريات، الافتراض الفرئ

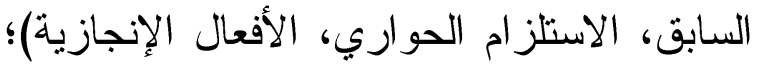

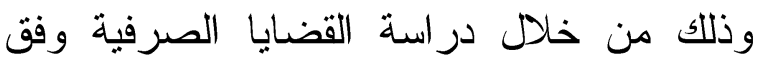

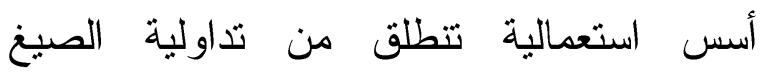
الصرفية في دائرة الخطاب الشعري.

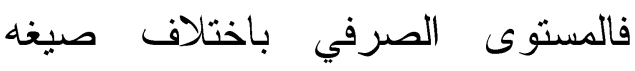

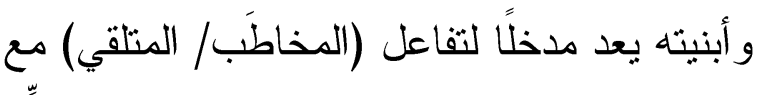
بنية النص الشعري وفق عناصر تداولية تركزّ

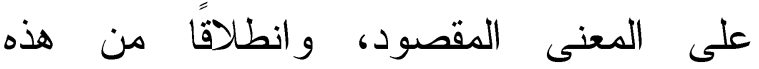
العناصر تحاول الدراسة الكشف عن ارتباط الصيغة الصرفية بالمعنى في ضوء التداولية.

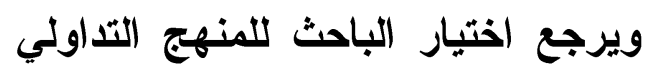
في التحليل؛ وذلك لما تتميز به التداولية من اهتمام بالمتكلم ومقاصده في الكلام، و اهتمامها

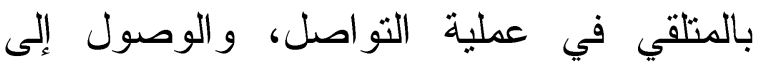
غرض المتكلم استتادًا إلى السياق المحيط بدائرة

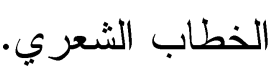

كما اعتمد الباحث على المنهج الوصفي التحليلي الذي يقوم بوصف الظاهرة الصرفية وتحليلها تحليًا لغويًّا للوقوف بلى بلى العناصر السياقية التي تحدد المعنى المقصود من الصيغة الصرفية في شعر طفيل الغنوي. وتكتسب هذه الاراسة أهميتها من كونها أول محاولة تدرس الصيغة الصرفية في ضوء

الثاعر (قبيلته، حياته، شخصيته)، و الباب الثاني: شعره (الديو ان، الموضو عات، در اسة فنية).

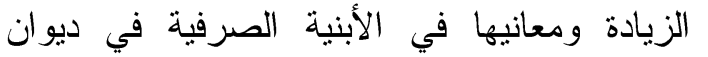

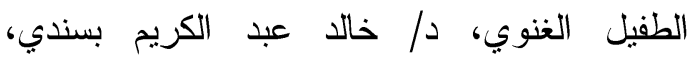
إصدارات مركز حد الجاسر الثقافي، الطبعة

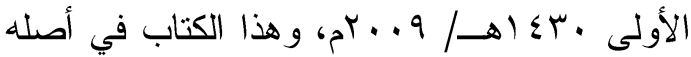
رسالة علمية تقدم بها الباحث إلى جامعة اليرموك عام ب99 ام لنيل درجة الماجستير •

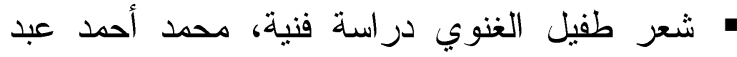

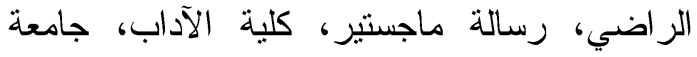

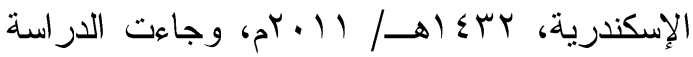

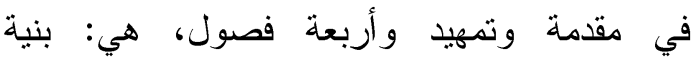

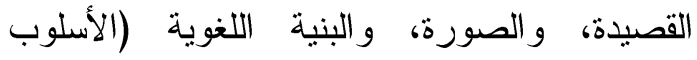
الخبري والأسلوب الإنشائي) و البنية الموسيقية، و و الخاتمة.

• المشتقات في الأسفار الأدبية في عبرية العهد القديم

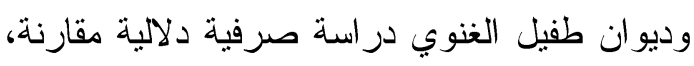

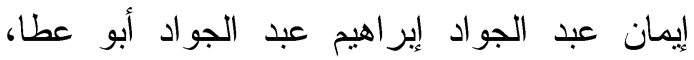
رسالة دكتوراه، كلية الآداب، جامعة الإسكندرية،

$$
\text { . }
$$

(r) من هذه الار (بسات ما بلإي:

• قراءة في بائية طفيل الغنوي (بالعفر دار من من بل

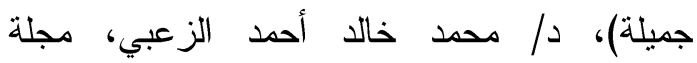

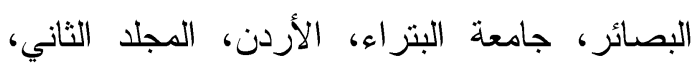

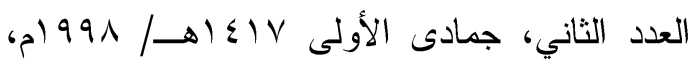
من صفحة اV إلى صفحة . . . . " دراسة ضمن كتاب: (بلاغة النص مدخل نظري

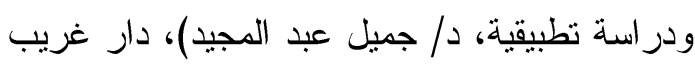

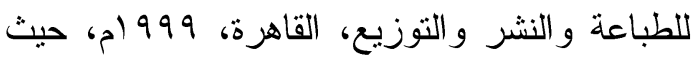
ضم الكتاب في قسم الدراسة التطبيقية دراسة

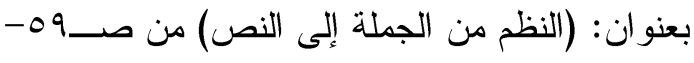

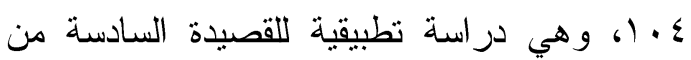

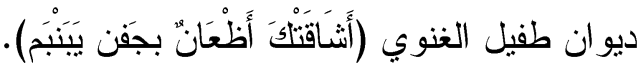


والتداولية تدرس اللغة في الاستعمال

تحقيقًا للتو اصل بين المتحاورين، و الحوار بتكون من أبنية ووحدات لغوية، وهذه الدراسة تحاول الكشف عن مدى قدرة الصيخ الصرفية على تحقيق هذا التو اصل؟.

وقد تشكلّ البحث من مقدمة ومحورين

للار اسة، المقدمة بيَّن الباحث فيها موضوعَ

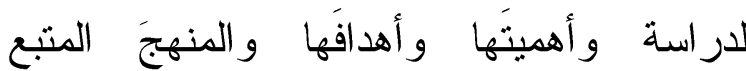
و الدر اساتِ السابقة وحدودَ البحث، ثم المحور الأول: الإطار النظري (تحرير المصطلح)، ويتتاول المصطلحات التالية: (الصيخة، المعنى، التداولية)، ثم المحور (الثاني: الإطار التطبيقي ويشمل ثلاثة مباحث هي: المبحث الأول: الوظيفة التواصلية في ظاهرة

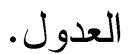

المبحث الثاني: تعدد الصيغ الصرفية للمعنى

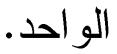

المبحث الثالث: تعدد المعنى في الصيغة

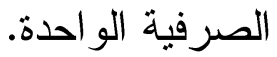

ثم الخاتمة والنتائج التي توصل إليها الباحث في الدراسة، يليها ق قائمة المصادر و المر اجع في نهاية الدر اسة.

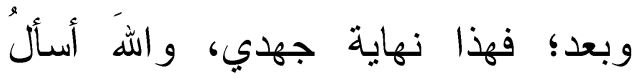
التوفيق، وما توفيقي إلا باله عليه توكلت و إليه أنيب، وهو حسبي ونعمَ الوكيل.
التداولية، فقد قام عدد من اللغويين و الباحثين(ء) بدر اسة القضايا النحوية في ضوء التذاولية، ولم يتطرق البحث اللغوي - على حد علم الباحثإلى علاقة التداولية بالصرف أو الدراسات الصرفية، ومن ثََّّ تأتي أهمية هذه الدر اسة. و الصيغ الصرفية في الاستعمال اللغوي (البناء النصي للقصيدة) ليست قوالب جامدة، و إنما هي منطوقات لغوية ينطق بها الثاعر للتعبير عن قصده لإيصاله إلى المتلقي في إطار لغوي تكثفه عناصر التداولية، وترتبط الصيغ الصرفية بعناصر التركيب الذي وردت فيه؛ فيكون لها دور في تحقيق التزابط الشكلي و الدلالي؛ ومن ثم فهي - كوحدات لغوية منطوقة داخل الجملة - لها دور بحقق التواصل بين عنصري الخطاب تظهره التداولية بعناصر ها المختلفة.

(؛ ) أظر على سبيل المثال: • علم المخاطب بين التوجيه النحوي والتداولية، د/ عمر محمد أبو نواس، المجلة الأردنية في اللغة لئة

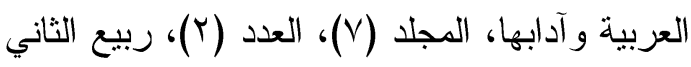

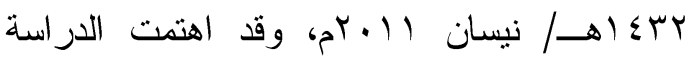

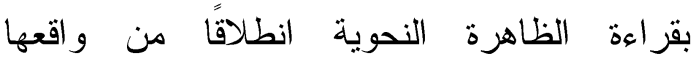
الاستعمالي التداولي. • منزلة معاني الكلام في النظرية النحوية العربية مقاربة تداولية، معاذ بن سليمان الدخيل، الطبعة

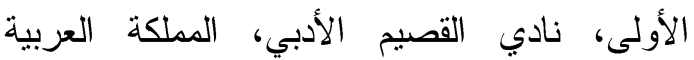

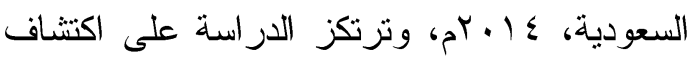

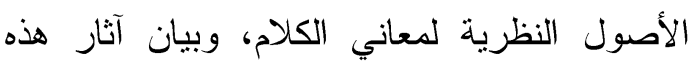
الأصول في التقعيد النحوي في أبو ابه المختلفة. 
وهناك تداخل بين مصطلحي: (الصيغة)

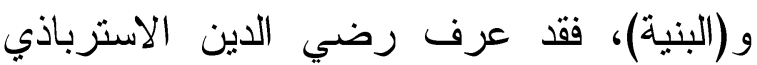

الصيغة بقوله: "المراد من بناء الكلمة ووزنها

وصبغتها: هيئتها التي يمكن أن يشاركها فيها غيرها، وهي عدد حروفها المرتبة وحركاتها المعينة وسكونها مع اعنبار الحروف الزائدة

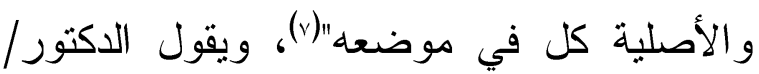

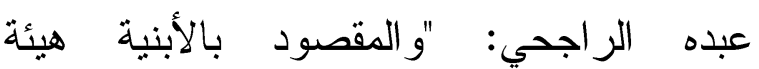

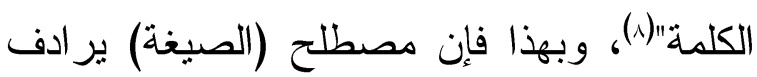
مصطلح (البنية) عند بعض اللغويين. و الفرق بين الصيغة والميزان يكمن في الينان

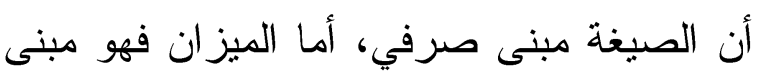
صوتي، يقول الدكتور/ تمام حسان: "فالتفريق بين الصيغة وهي (مبنى صرفي) وبين الميزان

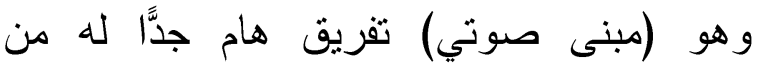

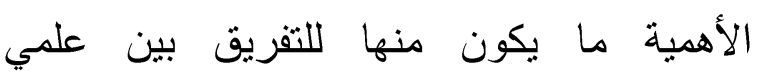
الصرف و الأصو ات" (a).

و الصيغة عنصر من عناصر بناء

المعنى، فهي تخصص البناء الصرفي بدلالة محددة، كتخصيص معنى الفاعلية في صيغة

(") شرح شافية ابن الحاجب، تأليف: الثيخ رضي الدين

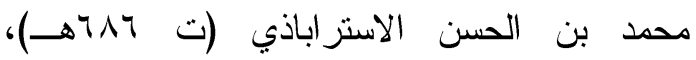

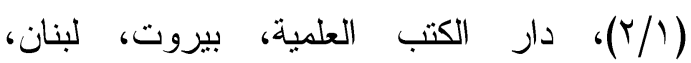

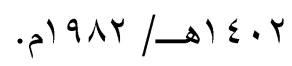

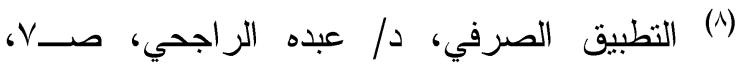
الطبعة الثانية، دار المعرفة الجامعية، الإسكندرية،

(9) اللغة العربية معناها ومبناها، د/ تمام حسان، صــ إ، الطبعة الثالثة، عالم الكتب، القاهرة،
المحور الأول : الإطار النظري ( تحرير المصطلح ).

(أ) - أصيفة الصرفية.

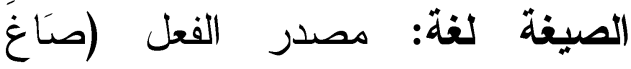

يَصوغ)، جاء في معاجم اللغة: "هذا شيءٌ حسَنُ

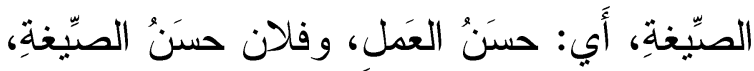

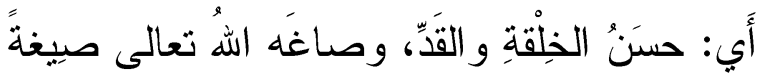

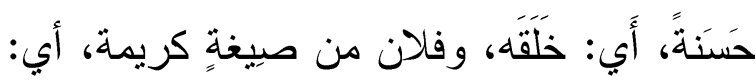

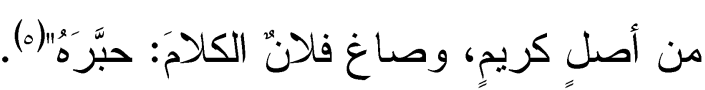
و الصيغة اصطلاحًا: "الهيئة العارضة العانة للفظ باعتبار الحركات و السكنات، وتقديم بعض الحروف على بعض، وهي صورة الكلمة

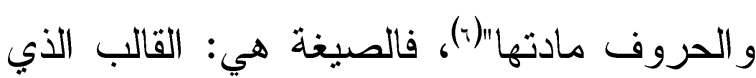

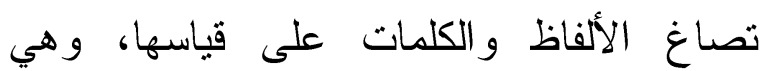
المبنى الصرفي للأسماء و الأفعال.

(0) أساس البلاغة، نأليف: أبي القاسم جار الله محمود بن عمر بن أحمد الزمخشري (ت بلبهـهـ)،

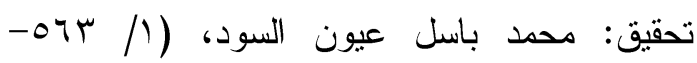
ع 07)، مادة (صوغ)، الطبعة الأولى، منشورات: محمد علي بيضون، دار الكتب العلمية، بيروت، الكان، لبنان، 9 1§ (هـ/ 991 ام، ولسان العرب، تأليف: الإمام جمال الدين أبي الفضل محمد بن مكرم بن النان منظور الأنصاري (تالإلهـ)، تحقيق وتعليق:

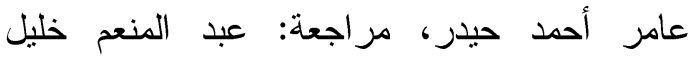

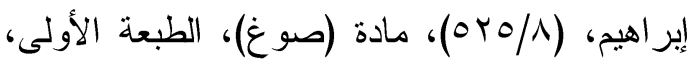

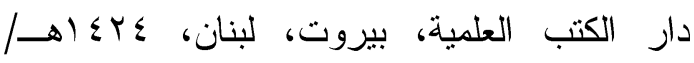
. (?) الكليات (معجم في المصطلحات و الفروق اللغوية)

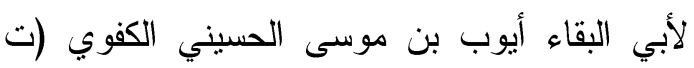

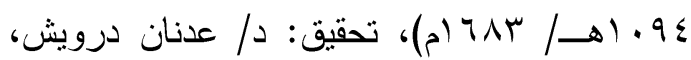
محمد المصري، صـ. 07، الطبعة الثانية، مؤسسة

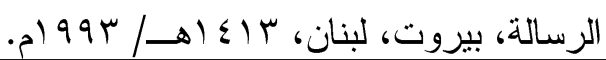


وقد أشار اللغويون إلى انحباز الصبغة

الصرفية إلى معنى أساسي يغلب عليها و إن

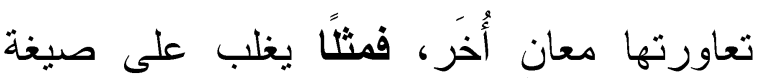
(انْفَكَ) معنى المطاوعة، وإن شعاركتها صيخ

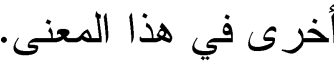
(ب) - المغنى.

إن قضية المعنى تشكل النظرية الصرفية

عند العرب، فهي الغاية الأولى والهدف المنشود

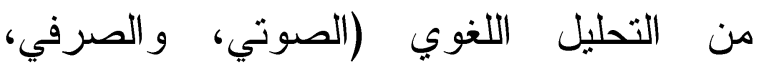
و النحوي)، وقد اهنم اللغويون بقضية المعنى (1)، و انصب اهتمام الصرفيين على المعنى من خلال اهتمامهم بمعاني الصيغ الصرفية، فضم التراث الصرفي كمّا لا بأس به من الأبواب الصرفية التي تثبت اهتمام الصرفيين بالمعنى، فهو مقصد

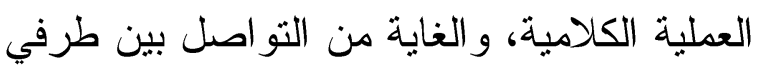
الخطاب (المتكلم و المخاطب). "و المعنى ليس شيئًا متأصلًا في الكلمات وحدها، ولا يرتبط بالمتكلم وحده و لا السامع وحده، فصناعة الكلام تتمثل في تداول اللغة بين

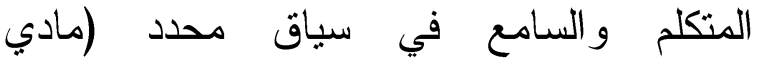
وراجتماعي ولغوي) وصولًا إلى المعنى الكامن في كلام ما"(r). (1).

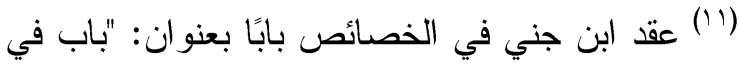
الرد على من ادعى على العرب عنايتها بالألفاظ

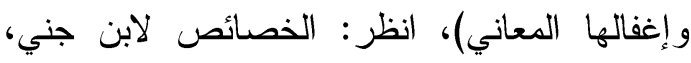

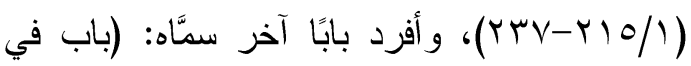

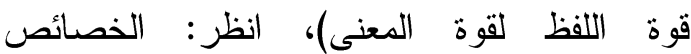
. (rTV/r) (r'ا آفاق جديدة في البحث اللغوي المعاصر ، د/ محمود

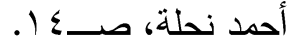

(فَاعل))، أو معنى المفعولية في صيغة (مفعول)، أو معنى المبالغة في صيخ (فَعُول، فَعِيل، فَعَّال

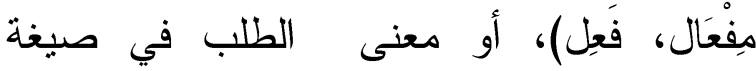

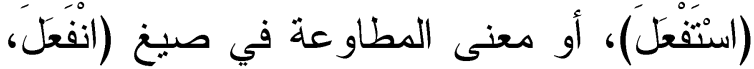

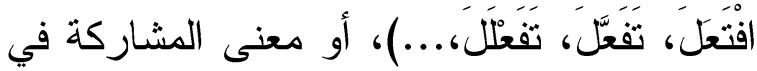

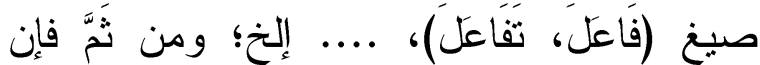
مبنى الصيغة الصرفية يسهم في تشكيل معنى الكلمة في السباق الوارد فيه.

وقد رصد الصرفيون في مصنفاتهم عددًا من المعاني التي تدل عليها كل صيغة، واهتموا بدراسة الصيغ في أبواب الصرف؛ لما في ذلك من كثفٍ للمعنى المرتبط بدلالة البناء الصرفي المصاحب للصيغة، و إن التنوع في استعمال الصيغ الصرفية يتبعه تتوع في المعنى الذي

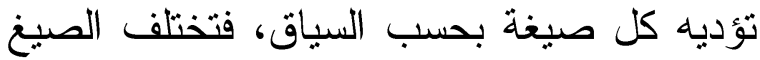
الصرفية في النص تبعًا للالالة التي تؤديها كل صيغة بحسب مر اد المتكلم وقصده. وقد حظيت الصيغ الصرفية بعناية

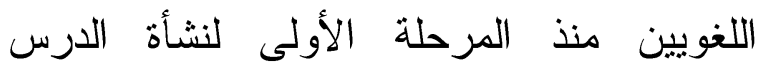
اللغوي، فقد تتبه القدماء إلى أهمية الصيغة الصرفية من ناحية الدلالة المعنوية، فهذا أبو لألهاء

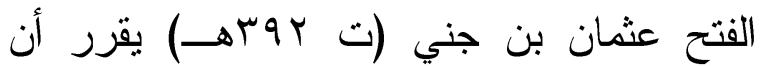
اختلاف بنية الكلمة يفضي إلى اختلاف معناها(.). (ختلاف (·) (انظر: الخصائص، صنعة: أبي الفتح عثمان بن جني، تحقيق: محمد علي النجار، (ץ/. . 1-ب . (1)،

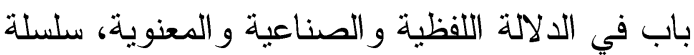

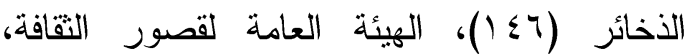

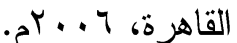


التراث النحوي؛ مما يوضح أهمية المعنى في لئي

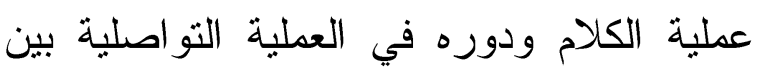
المتكلم و المخاطَب.

$$
\text { (ج)- التداولية. }
$$

التذاوليَّة Pragmatics مصطلح مركب

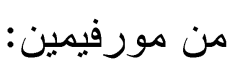

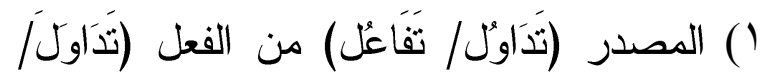
تَفاعلَ)، الذي يفيد معنى المشاركة.

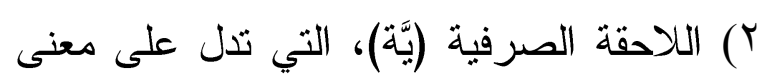
المصدر الصناعي.

فالصيغة الصرفية لمصطلح التداوليَّة تفيد معنى المشاركة بين طرفين، هما: (المبدع

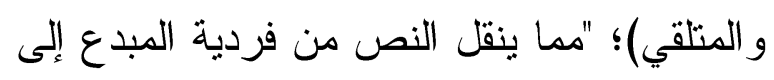
ثنائية التفاعل بين المرسل و المرسل إليه،

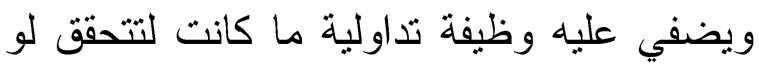

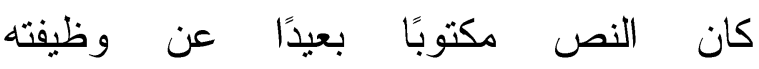
الإببلاغية"(:)؛ فالتداولية تعتدد في الدقام الأول على البعد التواصلي للغة؛ ولذلك تهتم بدراسة

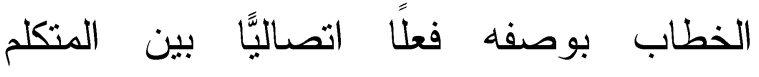
و المخاطَب.

وباستعر اض المادة اللغوية (دَولَ) في المعاجم العربية(1) نجد أنَّها تدور حول التتاقل

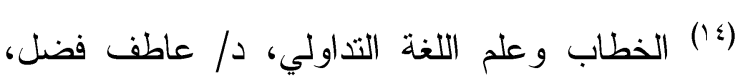
صـــآب، مؤتمر "لغة الخطاب في العصر الحديث

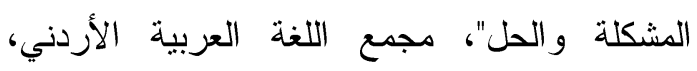
عمّان، محرم مبأهأهـ/ تشثرين الثاني (نوفمبر) (5) (10) يقول الزمخشري: "أدال الله بني فلان من عدوهم،

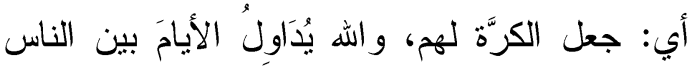

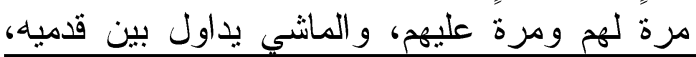

و المعنى هو: الدلالات التي يتصورها الذهن عند سماعه الألفاظ اللغوية، أو عند قراءته الكلام المكتوب، وربما كان المعنى حصيلة لمفردة واحدة أو جملة، أو ربما كان حصيلة وربية لتفاعل نسيج من الجمل، ويمكن النظر إلى ونى المعنى من جانبين، الأول: يتعلق بكيفية تشكله

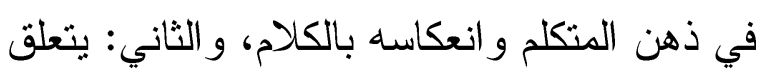
بكيفية تشكله عند المتلقي الذي بستقبل الكلام(ب). وقد شغلت قضيةُ المعنى اللغويين عمومًا

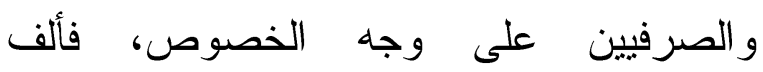

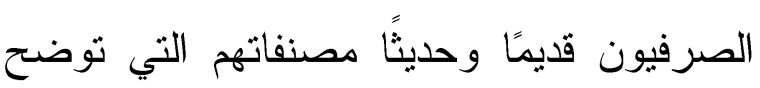

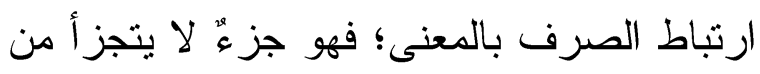

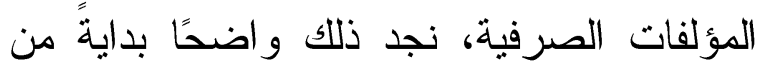
الكتاب لسيبويه ومرورًا بـــتاب التصريف للمازني، وشرح ابن جني لله في كتابه لهنيه

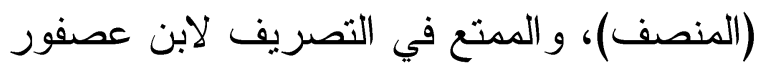

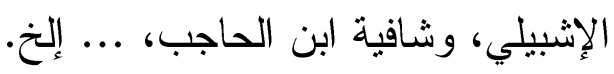
وقد أدى اعتماد المفسرين على المعنى في القضايا الصرفية إلى توجيه كثير من المسائل الفقهية في كتب التفسير، كما أدى اعنماد اللغويين على المعنى إلى بناء كثير من القواعد

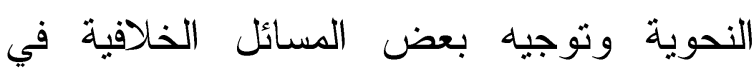

(1) المتلقي هو مستقبِل الكلام الذي يتكون في ذهنه المعنى؛ ولأهمية المتلقي في تكوين المعنى نثأت

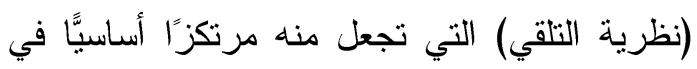
تثنكل معنى النص اللغوي، انظر: المعنى وبناء

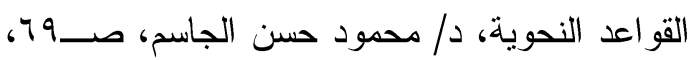

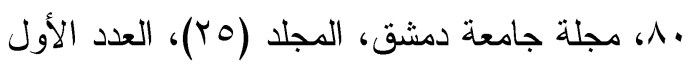

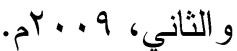


بعنوان (How to do things with words) كيف نصنع الأشياء بالكلمات، قدم فيه تحليًا لظاهرة الخطاب (أفعال الكلام Speech acts)، مركزًا على سياق التلفظ وظروف إنتاج الخطاب، ثم جاء الفيلسوف الأمريكي جون سيرل John Searl فأضاف تعديلات على جلى الأل مجهودات (جون أوستين)؛ وذلك في كتابه:

(Speech acts) وقد ترجم مصطلح (التداولية) بعدة ألفاظ، منها: (التبادلية، السباقية، الاتصالية، النفعية، الذرائعية)؛ وذلك بسبب تداخل حقول التداولية بحقول معرفية أخرى، فهي تمثل حلقة وصل بين حقول متعددة.

وقد تعددت تعريفات التداولية في الدرس

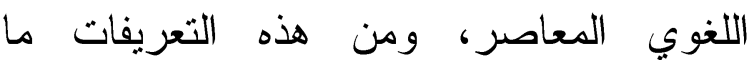
يلي (1،):

أسس جون أوستبن تداولية أفعال الكلام، وقد (IV)

غيرت أعماله مجرى الدراسات اللسانية في العيرة العشرينات الأخيرة من القرن الماضي، وقدم جون

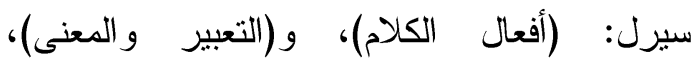

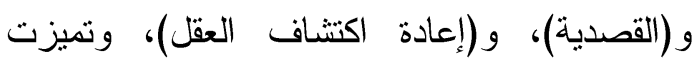
الحقبة الزمنية المعاصرة له بنمو المعرفة، انظر:

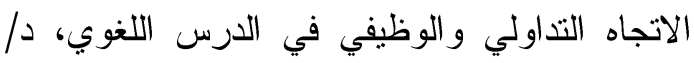

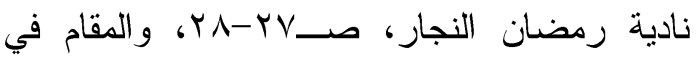
الثعر الجاهلي تناول تداولي لمعلقتي عمرو بن

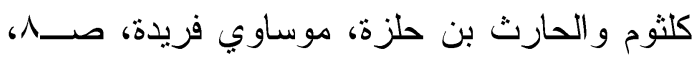

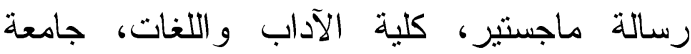

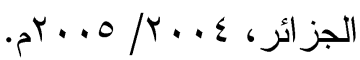

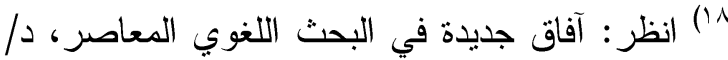

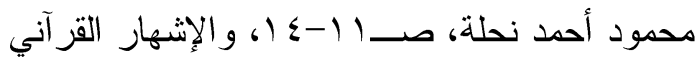
و المعنى المعرفي في ضوء الهدة النظرية العرفانية
و التحول، وهذه طبيعة اللغة تنتقل من المبدع إلى

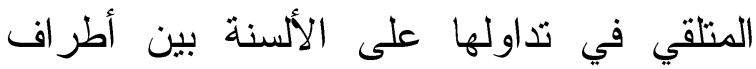

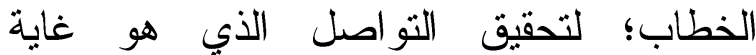

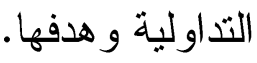

ويعود التداولية بمفهومه الحديث إلى الفيلسوف Pragmatics Charles Morris الأمريكي تشارلز موريس

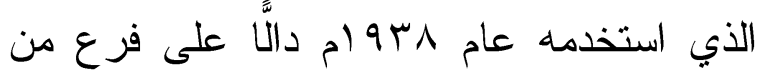
فروع ثلاثة يشتمل عليها علم العلامات، هذه مأه الفروع هي: (علم التراكيب Syntax، علم الدلالة Semantics، التداولية Pragmatics)، ولم تستقل التداولية كدرس لغوي قائم بذاته إلا في العقد السابع من القرن العشرين على يد مجموعة من فلاسفة اللغة الذين عملوا على الثىن صياغة مفاهيمها ووضع قو اعدها، و على رأسهر:

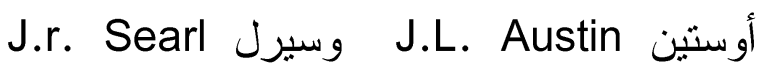
وجريس (19)H.P. Grice فقد أصدر الفيلسوف الإنجليزي جون أوستين John Austin عام .97 ام كتابه:

أي: يراوح بينهما"، أساس البلاغة للزمخشري،

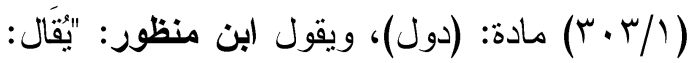

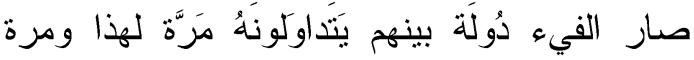

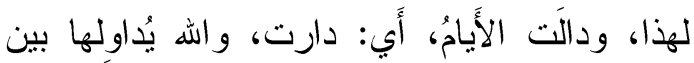

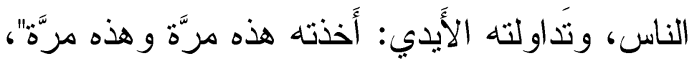

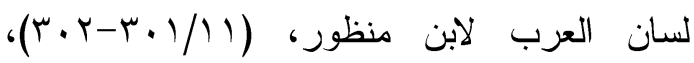
مادة: (دول). (19) انظر : آفاق جديدة في البحث اللغوي المعاصر، دم/

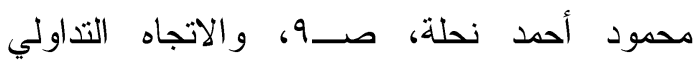
والوظيفي في الدرس اللغوي، د/ نادية رمضان

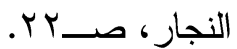


وتشمل عملية الاتصال اللغوي كل

ما يتصل بالخطاب؛ فتشمل الغاية من الحدث العن الكلامي (قصد المتكلم)، وهي الغاية التو اصلية الإبلاغية التي بريد المبدع تحقيقها

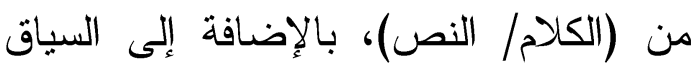
Context الكلامي، وتتم عملية التواصل اللغوي بفهم الإهام المخاطَب الثفرة اللغوية (الرسالة/ النص)، وحصول مبدأ الإفادة عنده، وتأني التداولية فتهت بكل عناصر الموقف التواصلي بين المتكلم و المخاطَ.

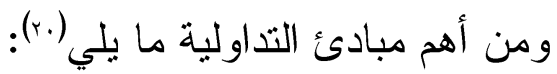

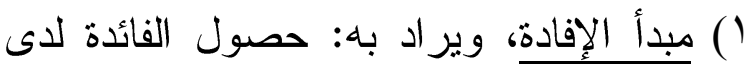
المخاطب، ووصول الرسالة الإبلاغية إليه على الوجه الذي يغلب على الظن أن يكون هو مراد الدتكلم وقصده، وهي الثمرة التي لتطي يجنيها المخاطَب من الخطاب.

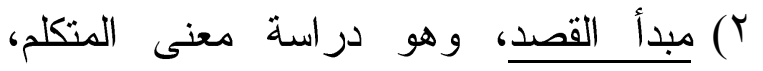
ويراد به: الغاية التواصلية الإبلاغية التي دولية يريد المتكلم تحقيقها من الخطاب. r) مبدأ مر اعاة الظروف المحيطة بين المتكل و المخاطَب: حيث تُعنى التداولية بالكيفية التي لئي تستعمل بها اللغة عند الحديث، وتهتم بالسياق الكلامي، وتُعنى بالمتكلمين وطر ائق حديثهم، وبكل ما من شأنه أن يزيد عملية الاتصال

(r.) انظر: التداولية عند علماء العرب، مسعود صحر اوي، صــ10 ا-Y.r.r، وعلم المخاطب بين التوجيه النحوي و التداولية، دم/ عمر محمد أبو

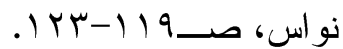

() دراسة اللغة من وجهة نظر وظيفية .functional perspective ץ) فرع من علم اللغة يبحث في كيفية اكتشاف speaker السامع مقاصد المتكلم intentions .speaker meaning r) دراسة اللغة في الاستعمال in use أو في التو اصل in interaction. §) علم يدرس الظواهز اللغوية في مجال

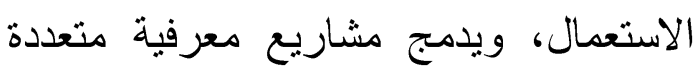
في دراسة ظاهرة النو اصل اللغوي وتفسيره،

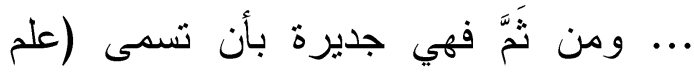
الاستعمال اللغوي)(19). ويتضح من هذه التعريفات أن التداولية تهتم بدراسة اللغة في سياق الاستعمالات المختلفة؛ لأن الهدف منها تحويل (الخطاب) المنطوق) إلى أفعال منجزة في سياق الاستعمال المتداول بين عنصري الخطاب. و عملية التو اصل اللغوي تتشأ بين:

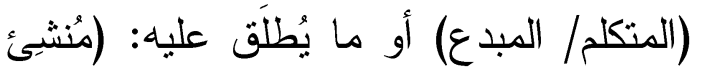

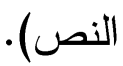
(المخاطَب/ المستمِع) أو ما بُطلَق عليه (متلقي النص).

والمزج المفهومي والتداولية، د/ عطية سليمان

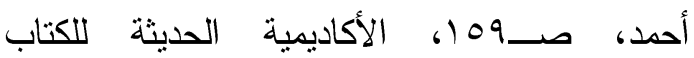

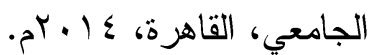

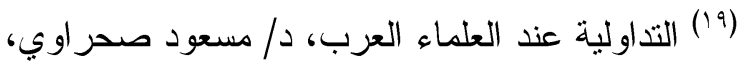


يحمله القول بصدقه ومجازه؛ فتبحث في كل ما من شأنه أن يقرب الفهم والتواصل بين المتكلم و السامع، وتسعى إلى صناعة معنى يكون

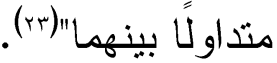

فالتداولية تدرس اللغة في سياق

الاستعمالات المختلفة، مع مراعاة كل ما يحيط بالحدث الكلامي؛ فتبحث في أغر اض المتكلمين ومقاصدهم من عملية الكلام، و اكتثاف المعاني الدلالية التي يريدها التنكلم من الخطاب (الصيخ والتراكيب)، وتراعي أحوال المخاطبين تحقيقًا للتواصل والتفاعل بين أطراف الخطاب؛ لأن

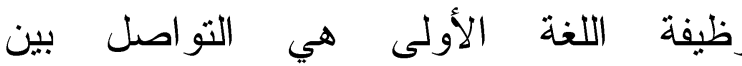

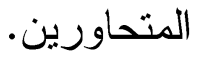

\section{المحور الثاني : الإطار التطبيقي.}

يقوم البحث التداولي على دراسة أربعة

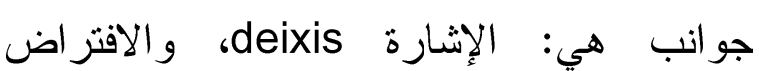
السابق presupposition، و الاستلزام الحواري conversational Implicature الكلامية Speech acts

أولنًا: الإشاريـات Deixis: هي الأشكال الإحالية

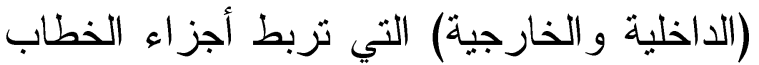
اللغوي، وتتحدد مرجعية الإشاريات (الإحالات) الداخلية بالروابط النصية التي تربط بين أجزاء التركيب اللغوي في الخطاب، أما مرجعية

(rr) التداولية النشأة و النطور، سحالية عبد الحكيم، (r)

$$
\text { صــ }
$$

(4) آفاق جديدة في البحث اللغوي المعاصر، د د/ محمود

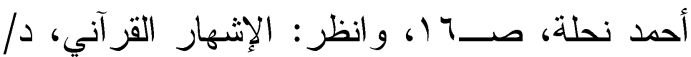

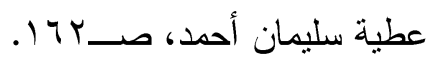

وضوحًا، فتهنم بالمتكلم والسامع والحدث التواصلي، وتهتم بظروف الكلام ومقام الحال، وبالسياقات اللغوية للمتكلمين، ... وبكل ما له صلة بالكلام من عو امل خارجية فتبحث في الكيفية الخطابية(1). وهكذا تهتم التداولية بالخطاب وبالعلاقة المتبادلة بين عنصريه لبيان مقاصد المتكلم، وحصول الإفادة عند المتلقي؛ ومن ثَُّّ ترتبط التداولية باللغة في سياق استعمالها؛ لتبحث في مدى نجاح العملية التواصلية بين المبدع و المنتقي.

وقد اهتم الصرفيون في تحليل الصيغ الصرفية بالمبادئ التداولية؛ فنظروا بعين الاعتبار إلى أهمية القصد عند المتكلم، و الإفادة

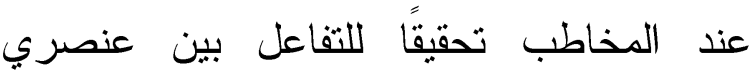
الخطاب، "فلو لا إدر الك المنكلم أن الدخاطَب بعلم ويتفهم المقصود لما نجحت العملية التواصلية، ولما أدى الكلام غرضه المقصود"(rrr).

The ( Tتهم التداولية بدراسة المعنى

meaning الدلالة تدرس المعنى بمعزل عن المواقف المحيطة به، بخلاف التداولية التي تهنم بدراسة

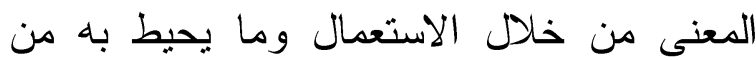
السياق و المقام وغرض المتكلم "وكل ما يمكن أن

(r)(انظر: التذاولية النشأة و التطور، سحالية عبد

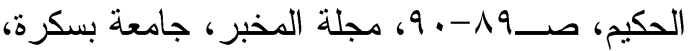

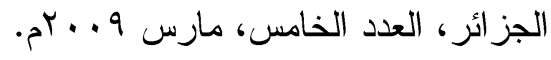

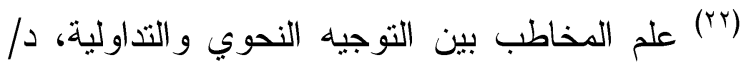

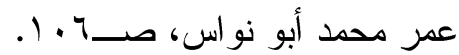


وتحصل ظاهرة الاستلز ام الحواري إذا تم خرق

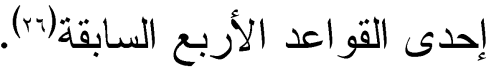
رابعًا: الأفعال الكلامية Speech acts: أسس السع

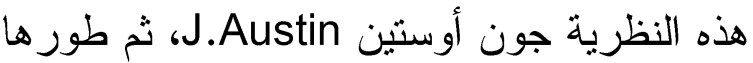

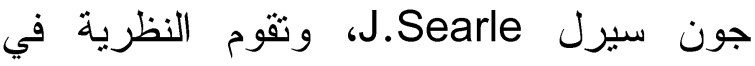
أساسها حول قصدية المتكلم في الخطاب. ويرى جون أوستين أن الفعل الكلامي له ثلاث خصائص: أنه فعل دال، و إنجازي،

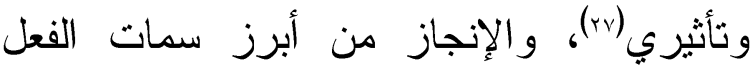
الكلامي، و المقصود بالإنجاز : إنجاز الأفحال في الإني

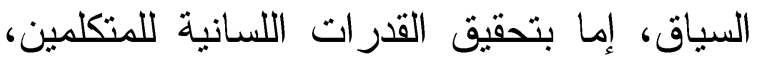
و وإما بتحقيق القدرة التواصلية بين المتكلمين (ب٪)، والفعل الإنجازي illocutionary act هو ما يؤديه الفعل اللفظي من معنى إضافي يكمن خلف الإنا المعنى الأصلي (4a).

وسيعتمد الإطار التطبيقي في هذه

الدراسة على بيان دور العناصر التداولية: (الإثاريات، الافتر اض السابق، الاستلز ام

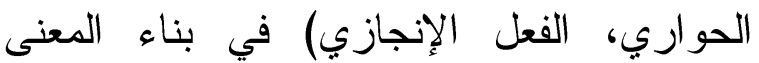

(די) آفاق جديدة في البحث اللغوي المعاصر، د/ محمود

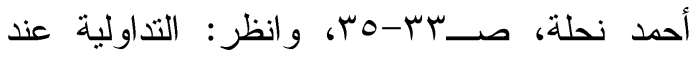

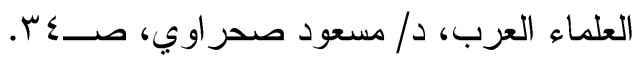

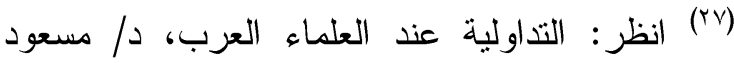

$$
\text { صحر اوي، صــء ؛. }
$$

استراتيجية الخطاب الحجاجي دراسة تداولية في

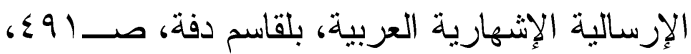

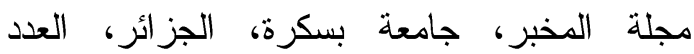

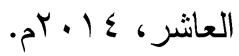

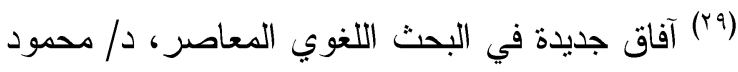

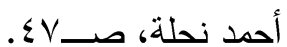

الإشاريات (الإحالات) الخارجية فتتحدد من خلال معرفة السياق المحيط بالخطاب، وتربط الإشاريات الخارجية بين المتكلم والخطاب و المتلقي.

و الإشاريات تزيل الغموض في النز اكيب

النصية بايضـاح المعنى، وتؤدي دورًا بارزًا في تز ابط النص وتسلسل الأفكار، وهذا بدورِِ يسهح في إبراز المعنى التداولي، وتحقيق التو اصل بين عنصري الخطاب.

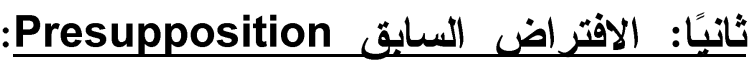
هو معلومات و افتر اضات مسبقة (مدركة) بين المتكلم و المخاطَب تُفهَمْ من خلال السياق، حيث

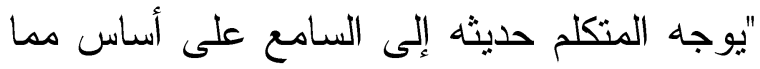

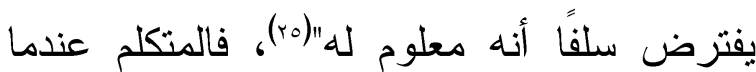
يُنشيئ خطابَهُ يُفترَض أن المتلقي عنده معرفة لهُه ببعض جو انب هذا الخطاب؛ ومن ثَُّّ يظهر دور الافتراض السابق في تحقيق التواصل و التفاعل بين عنصري الخطاب.

ثالثًا: الاستلز ام الحواري Implicature الجوانب في الدرس التداولي، فهو ألصقها بطبيعة البحث فيه، وهو متغير بتغير السياقات التي يرد فيها، ويحكمه مبدأ التعاون بين المتكلم

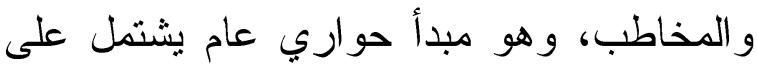

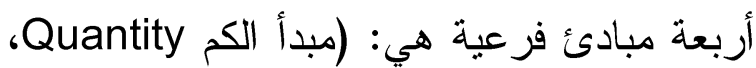
مبدأ الكيف Quality، مبدأ المناسبة Relevance (ro) آفاق جديدة في البحث اللغوي المعاصر، د/ محمود

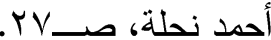


من الشعر ومحاولة إعطاء المعنى الذي يريده

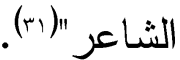

و العدول يرثبط بقصد المتكلم للتعبير عن

مقاصد تداولية في سياق الاستعمال بين المبدع و المتلقي؛ لأن الصيغة الصرفية التي عُدِل إليها تحمل في بنائها اللغوي معنى جديدًا لا تحمله الصيغة الأخرى (المعدول عنها).

يقول ابن الأثير: "أما اختلاف صيغ الألفاظ فإنها إذا نقِلت من هيئة إلى هيئة كنقلها

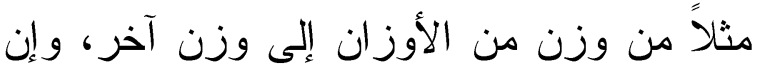
كانت اللفظة واحدة، أو كنقلها من صيغة الاسم إلى صيغة الفعل أو من صيغة الفعل إلى صيغة الاسم ... انتقل قُبحُهَا صار حُسنْا، وحُسنْها صـار قُبحًا"(rr)، فالعدول عن صيغة إلى صيغة أخرى لا يكون إلا لفائدة لغوية أو معنى مغاير في

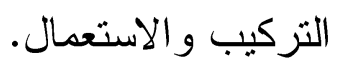
وقد تتبهت الدراسات اللغوية إلى دور المنكلم في ظاهرة العدول بمر اعاة الاستعمال التداولي بينه وبين المخاطَب، فالشاعر يوجه الصيخة الصرفية في النص وفق أسس استعمالية تداولية تهدف إلى إبراز قصده من استعمال هذه

('ا") ظاهرة التحويل في الصيغ الصرفية، د/ محمود سليمان ياقوت، صــ لا، الناشر: دار المعرفة الجامعية، الإسكندرية، 910 أم. (rr) المثل السائر في أدب الكاتب و الثاعر لضياء الدين

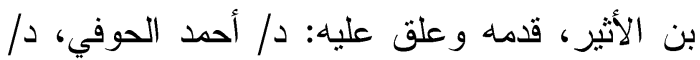

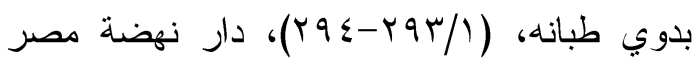
للطباعة و النشر، القاهرة، د.ت.
التداولي في لغة الخطاب الشعري عند طفيل الغنوي وإبراز قصدية الثاعر من خلال هذه

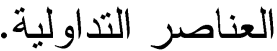

\section{المبحــث الأول : الوظيفــة التواصـلية في ظــاهرة}

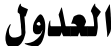

العدول هو: الانتقال من صبغة صرفية

إلى صيغة صرفية أخرى بيتلابها المقامُ

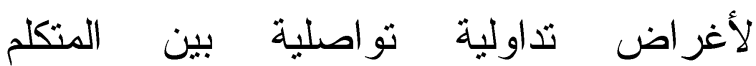
و المخاطَب، وللسياق دوره البارز في توجيه ظاهرة العدول الصرفي. وقد عُرفت ظاهرة العدول بمصطلحات عديدة، منها: الانزياح، و التجاوز، و العدول... يقول عبد السلام المسدي: "وعبارة (انزياح) تزجمة حرفية للفظة Ecart على أن المفهوم ذاته قد يمكن أن نصطلح عليه بعبارة (التجاوز)؛ أو أن نحيي له لفظة عربية استعملها البلاغيون في سياق محدد وهي عبارة (العدول)(.r). و العدول في الصيغ الصرفية "له صلته الوثيقة بالدلالة، فإن القدامى من العلماء العرب حين بشيرون إلى تحويل صيخة إلى أخرى كانو إس يربطون هذا التحويل بالدلالة، وهذا الربط في معظمه نجده حين يفسرون آيات القرآن الكريم، أو توجيه إحدى القراءات القر آنية، أو تفسير بيث

(•) الأسلوبية والأسلوب، عبد السلام المسدي،

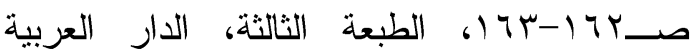




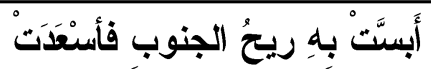

رَوَايا لله بالماعِ لمَّا تَصَرَّمِ

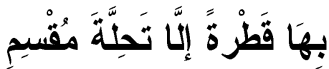

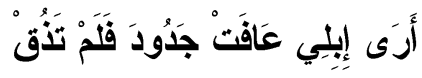

ويُنْيَانَ لم تُورد وقد تمَّ ظِمؤها

تراحُ إلىى جَوْ الحيَّاض وتَتَتْبِي

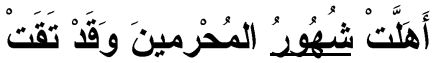

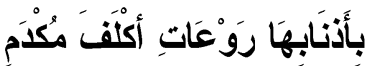

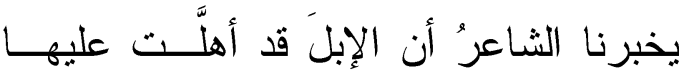

أثهر الحمل؛ فاتّت حينئذ هجمات الفحل عليهــا بأذنابها، فــ (شهور المحرمين) دلالةً على أشهر الحمل، والبيت الشعري "يصـــور الإبــل فــي علاقتها بالفحل، هذه العلاقة و إن كانت علاقــة امتتاع إلا أن هذا الامتتاع هو امتتاع طارئ، لم يصدر عن عدم رغبة، دل علــى هــــا جملـــة:

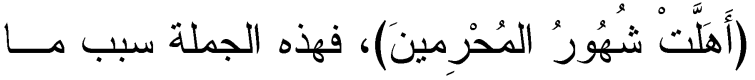

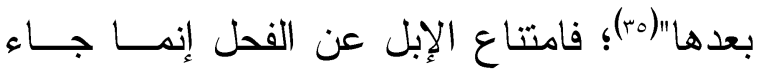
نتيجة دخولها في أشهر الحمل؛ ولذلك فقد اتَّقـــ الفحلَ بَأذنابها.

وقول الشاعر: (شُهُور/ فُعُول) جمع

تكسير، مفرده: (شَهْر/ فَعْل)، وهو اسم صحيح

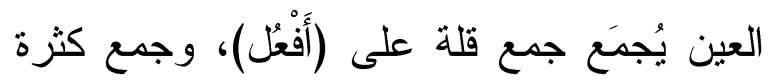
على (فُعُول)، والعدول يكون لوظيفة تواصلية بين المتكلم (مُنشيَ النص) و المخاطَب (مستقبِل النص) الذي يسهم في بيان معنى الصيغة الصرفية؛ لأنه جزء مهم في العملية التو اصلية. وقد عدل الشاعر عن جمع القلة إلى جمع الكثرة؛ ليؤدي الخطاب بهذه الصيغة

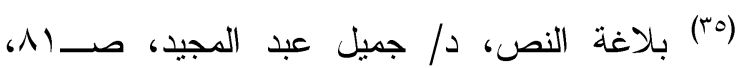

الصيغة الصرفية في لغة الخطاب دون غيرها من الصيغ الصرفية الأخرى. وظاهرة العدول فيها تجاوز الدلالة الأصلية للصيغة الصرفية إلى دلالات أخرى،

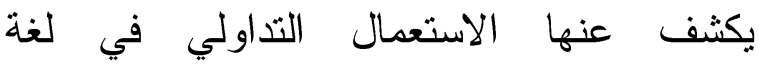
(الخطاب/ النص) للتواصل بين المتكلم و المخاطب، وتحقيق أهداف تداولية تخاطبية في

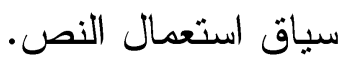
ومن صور العدول الصرفي في شعر

طفيل الغنوي ما بلي: (أ)- العدول عن جمع القلة إلى جمع الكثرة. بأتي جمع القلة للالالة على العدد من (س-. ())، وله أربعة أبنية صرفية، هي: (أَفْعُل،

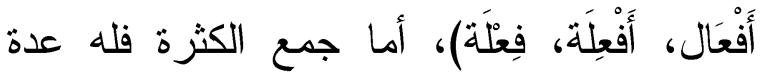
أوزان صرفية(r)، وتختلف دلالة التركيب باختلاف صيخة الجمع المستعملة فيه من حيث دلالتها على القلة أو الكثرة. و العدول عن جمع القلة إلى جمع الكثرة يكون لأغر اض بلاغية تداولية في لغة الخطاب الشعري، ومن ذلك قول طفيل الغنوي [من بن

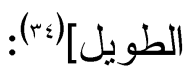

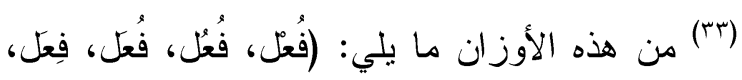

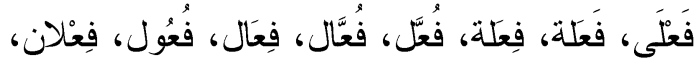

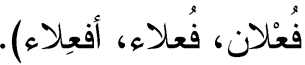

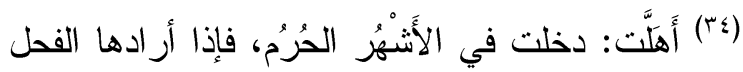

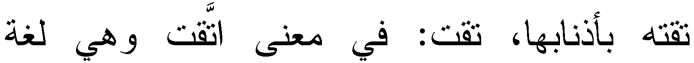
معروفة، و المكدم: الغليظ، ديوان طفيل الغنوي شرح

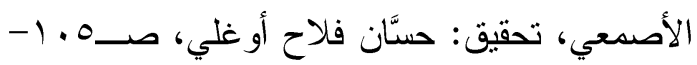

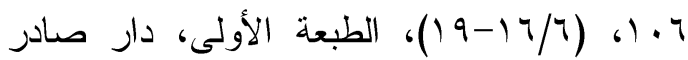


السالم مذكرًا كان أو مؤنثًا غير خاص بالقلة أو الكثرة، بل هو فقط لمطلق الجمع. ومن خلال العناصر السابقة ندرك قيمة

التداولية في بناء المعنى، وإيضاح قصدية المتكلم في بيانِ عفةٍ الإبلِ وامتتاعِها عن الفحل في أشهر الحمل، وإيضاح الوظيفة التواصلية في الإبي قصد المتكلم ومر اده.

(ب)- العدول عن المصدر الأصلى إلى المصدر الميمي.

المصدر: صيغة تدل على حدث غير

مرتبط بزمن، و المصدر الميمي ما دل على لدي

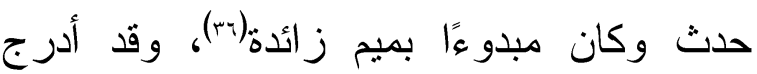

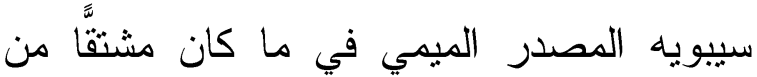

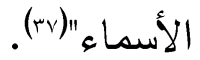

ويُعدل عن المصدر الأصلي إلى

المصدر الميمي؛ لتحقيق غاية تواصلية أو وظيفة تداولية، ومن ذلك عدول طفيل الغنوي عن

(") يشتق المصدر الميمي من الفعل الثلاثي على وزن

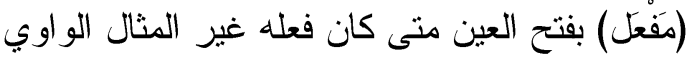

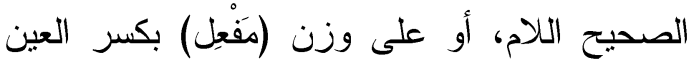

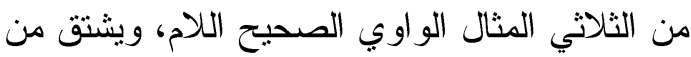

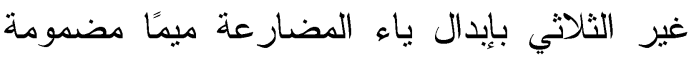

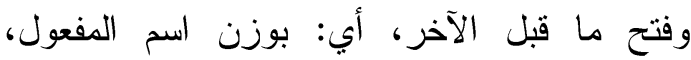
و السياق هو الذي يفرق بينهما في التركيب، انظر:

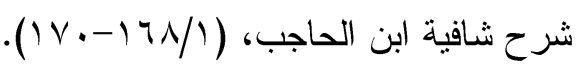

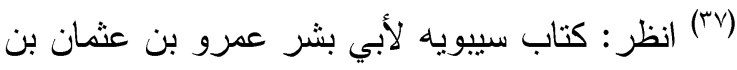

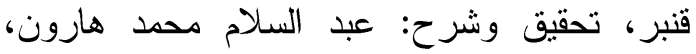

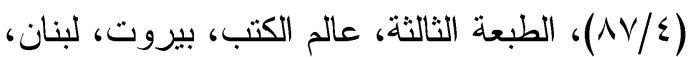

الصرفية وظيفة تداولية تتمثل في تكثير القليل وتضخيم عدد النوق التي ترفض الفحل. دور عناصر التداولية في بناء المعنى.

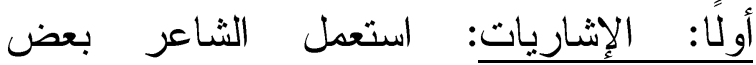
الإشاريات للربطبين الجمل والتزاكيب، فالضمير المستتر في قوله: (تقت بأذنابها) يربط

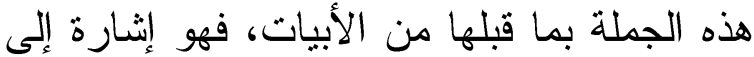

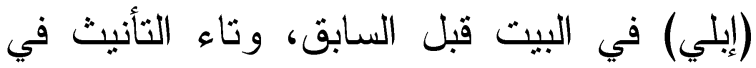
(تَقَتْ) إنشارة إلى الإبل أيضًا، وقوله: (بأذنابها)

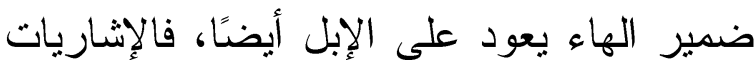

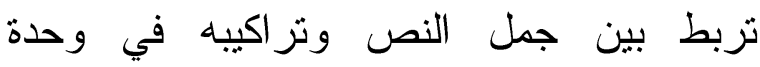
تز ابطية متتاسقة.

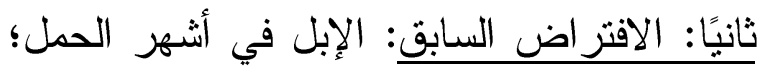
مما جعلها تمتتع عن الفحل وتثقيه بأذنابها.

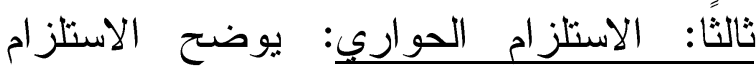
الحواري أن قصد المنكلم من قوله: (شهور المحرمين) هو أثهر الحمل، وليست الأشهر الحُرُم كما يتبادر إلى الذهن لأول وهلة، فالمتكلم

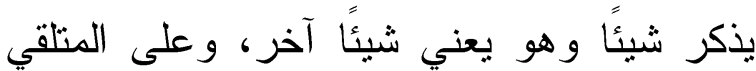
أن يُدرك ذلك تحقيقًا للتو اصل و التفاعل. رربعًا: الفعل الإنجازي: استعمل الثاعر الفعلين

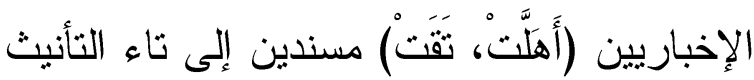

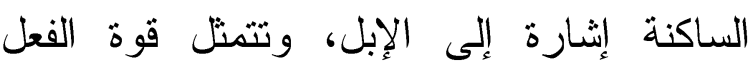
الإنجازي في عدول الثاعر عن لفظة (أشهر)

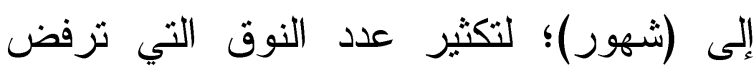
الفحول في أشهر الحمل. ألى أنير وقد أضاف الثاعر لفظ (شُُهُر) إلى لى

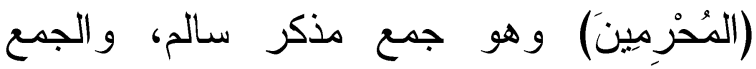


صيغة المصدر الأصلي لأهداف تداولية تتمنل في زيادة التعبير عن جمال هذه المر أة.

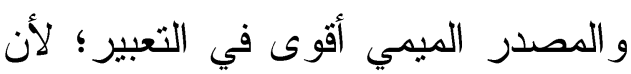
زيادة المبنى تستدعي زيادة المعنى، وقوة الفعل

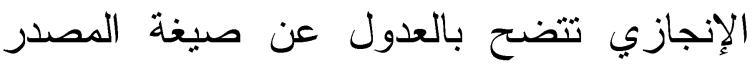
إلى استعمال صيغة المصدر الميمي.

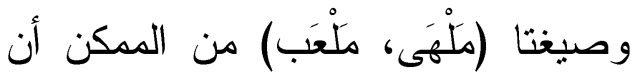

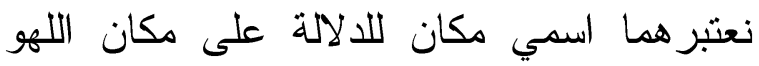

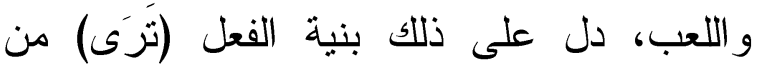

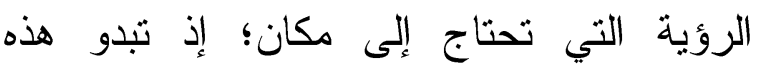

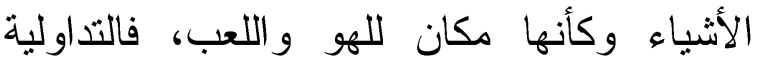
تتطلب من المتلقي أن يُعمل الذهن في فهم مر اد والحدث الإنجازي في لفظتي (ملهى) ملعب) أقوى دلالة من الحدث في صيغة المصدر

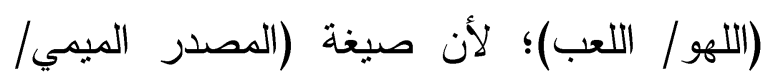
اسم المكان) تعطي قوة في الدلالة على اللهو و اللعب مع تلك المر أة التي يتحدث عنها في الثاعر يتضح ذلك من خلال عناصر التداولية. دور عناصر التداولية في بناء المفنى. أولًا: الإشاريات: تؤدي الإشاريات دورًا بارزًا في بناء المعنى التداولي في النص، والضمير في لئي شبه الجملة (فيها) عائد إلى (المر أة/ جميلة) التي لئي يتحدث عنها الثاعر من بداية القصيدة، و اللاصقة الصرفية (التاء) في أول المضارع

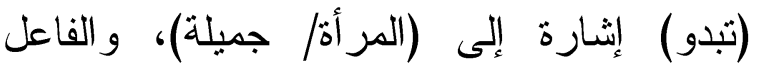

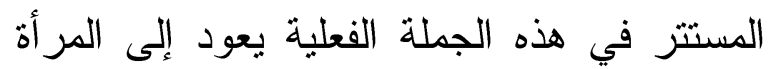
التي ذكرها الثاعر في مفتتح القصيدة؛ وبذلك التكاه تؤدي الإشاريات وظيفة الربط بين جمل النص.
المصدر (اللهو/ اللعب) إلى المصدر الميمي (ملهى/ ملعب) في قوله [من الطويل] (باد):

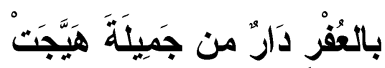

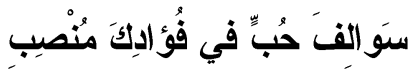

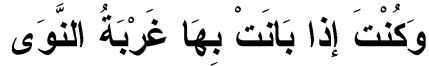

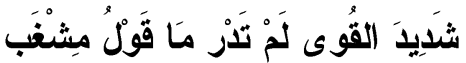

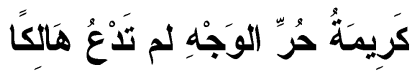

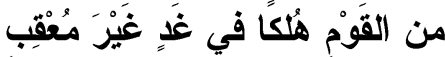

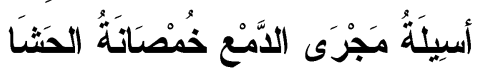

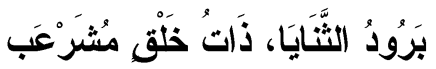

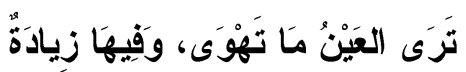

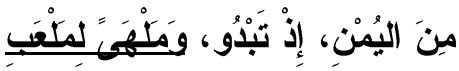

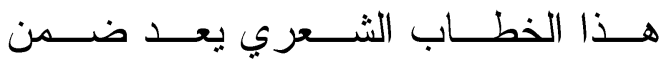
الإخباريات، وقد تتوعت صيغ الفعل في الخطاب

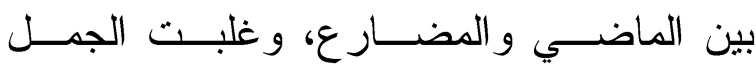
الإخبارية التقريرية على هذه الأبيات.

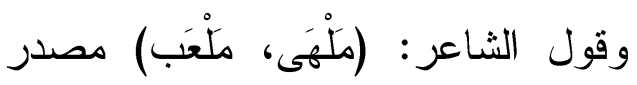
ميمي، استعمله الثاعر لوظيفة نواصلية تداولية

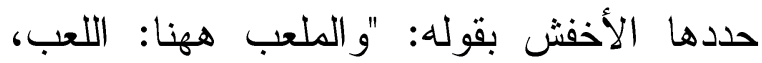

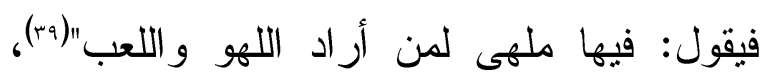
فاستعمال الثاعر صيغتي (ملهى، ملعب) دون لمن لهن

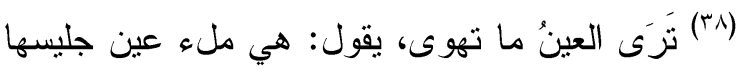

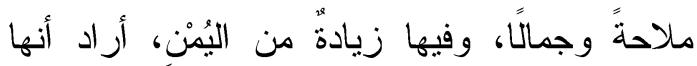

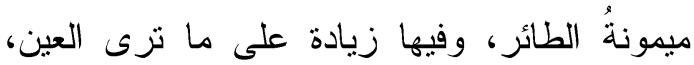

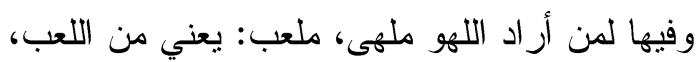

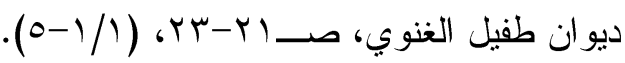

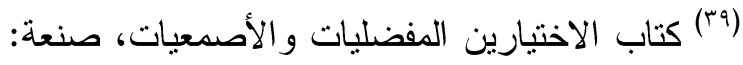

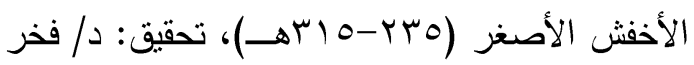

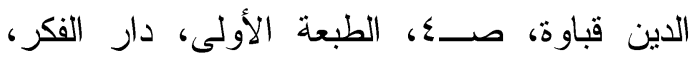

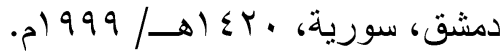


فكان العدول الصرفي عن صيغتي:

(اللهو/ اللعب) إلى صيغتي: (ملهى/ ملعب) لغاية تواصلية اقتضاها السياق بين المتكلم و المخاطَب، وهو التعبير عن جمال هذه المرأة، وفي هذا عدول عن استعمال صيغة المصدر لأجل تحقيق غاية نواصلية في بنية النص

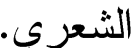

(ج)- العدول عن المصدر إلى اسم المرة.

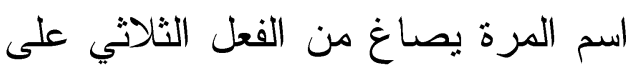

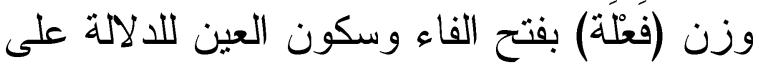

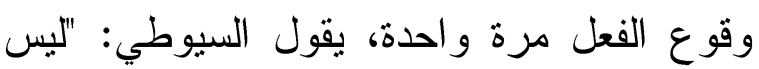
في كلامهم المصدر المرة الواحدة إلا على فَعَمَّة:

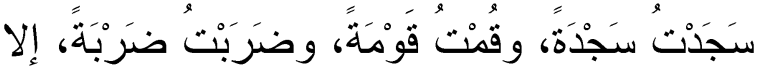

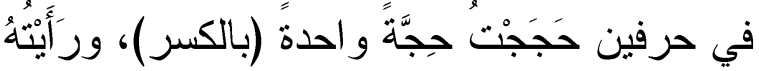

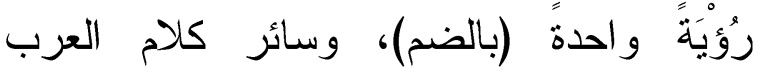

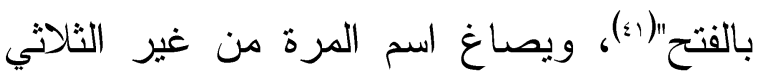
على وزن المصدر بزيادة تاء في آخره، فإذا كان المصدر منتهيًا بالتاء يضاف إليه كلمة (و احدة).

ويُعدل عن صيغة المصدر إلى اسم

المرة؛ لتحقيق وظيفة تواصلية بإفادة حدوث البى الفعل مرة واحدة، ومن ذلك عدول طفيل الغنوي

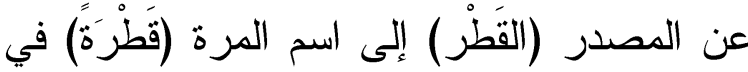

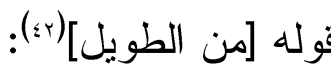

(1) المزهر في علوم اللغة وأنواعها للعلامة عبد الرحمن جلال الدين السيوطي، (ب/.^)، الطبعة الثالثة، مكتبة دار التراث، القاهرة، د.ت.

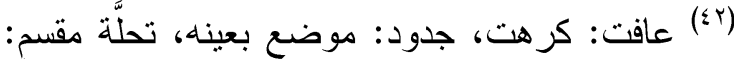
بقدر ما يحلّ المقسم أي قليل، و المقسم: الذي يقسم
ثانيًا: الافتراض السابق: الثاعر يتحدث عن امرأة جميلة يلهو ويلعب معها، دل على ذللك الكي حديثه عنها منذ بداية القصيدة. ثالثًا: الاستلزام الحواري: بدأ الشاعرُ قصبدَتَهُ الأولى في الديو ان بالتغزل في محبوبته؛ فاستعار من قاموس اللغة ما يُيرز جمال هذه المر أة بدءًا بالوقوف أمامَ دارها، ومرورًا بوصف جمال هذه المرأة؛ فاستلزم الحوار في القصيدة وصف المرأة بأنها (ملهى وملعب)، أي: مصدر للهو واللعب ومكان له؛ فعدل الثاعر عن صيغة المصدر الأصلي إلى (المصدر الميمي/ اسم المكان) دلالةً على أن هذه المر أة مصدرّ" للهو الهو الثاعر، بل مكان للعب أيضًا. رِابعًا: الفعل الإنجازي: استعمل الثاعر الفعل لإنابل

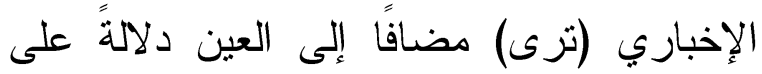
الرؤية الحسيَّة (البصرية)، والقوة الإنجازية في هذا الفعل تتمثل في إضافة معنى جديد، فالعين ترى في هذه المرأة الدلالَ و الجمال، إضافة إلى فلى الخير و اليمن، بل تزى العينُ فيها مكاناً ومصدرًا للهو و اللعب.

و التتوع في استعمال الصيخ نابع من تتوع المعنى المقصود من كل صيغة صرفية مستعملة في السياق التداولي، "و لا شك أنه لو لم لم يختلف المعنى لم تختلف الصيغة؛ إذ كل عدول عن صيغة إلى أخرى لابد أن يصحبه عدول عن

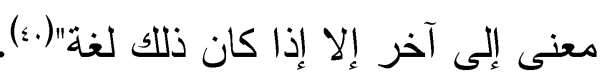

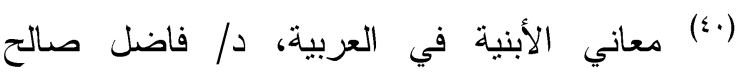

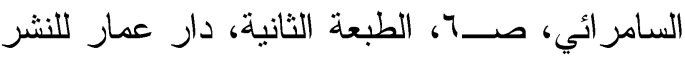

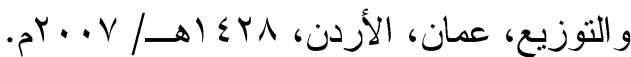




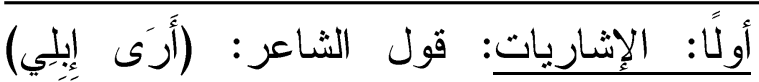

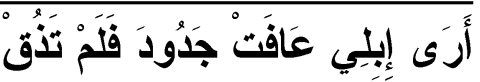

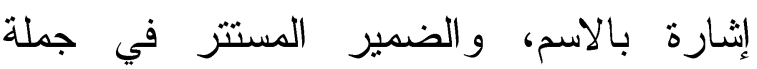
(عَافَت جَدُودَ) يعود إلى اسم سابق في الخطاب

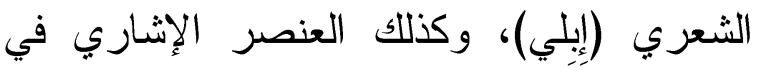

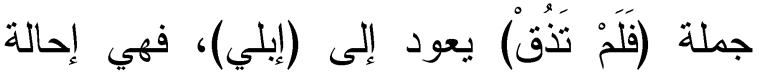

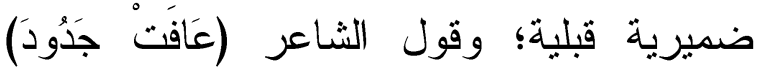

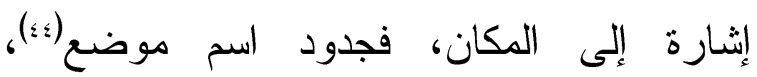
و العنصر الإشاري في شبه الجملة (بها) يعود إلى (جدود)، فهي إحالة بالضمير إلى اسم سابق؛

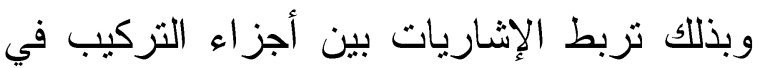
الخطاب الثعري؛ لتحقيق الهذف التذاولي الذي

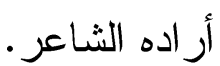

ثانيًا: الافتر اض السابق: الإبل ظَمَأَى لكن لعزة نفسها لم تذق الماءَ.

ثالثًا: الاستلزام الحواري: استلزم الحوار هناء

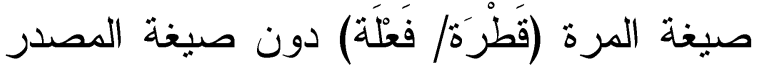

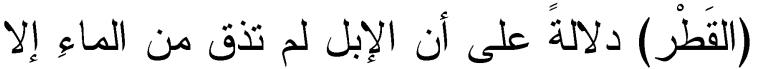
أقل شيء وهو القطرة؛ فالعدول عن صيغة المصدر إلى اسم المرة للالالة على قلة ما شُرب

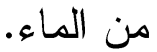
رابعًا: الفعل الإنجازي: تصدر البيت الشعري

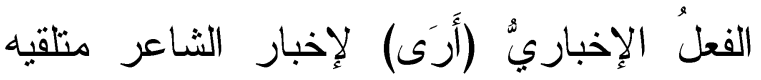
بعفة الإبل وبيان عزة نفسها، ثم استعمل الثاعر

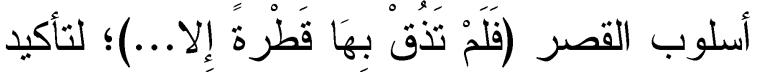
قصده في بيان عفة هذه الإبل، وتتمثل قوة الحدث الإنجازي في صيغة (قَطْرَة)، فقد عافَت ولَّن

(2) جدود: اسم موضع في أرض بني تميم، وكانت فيه وقعتان مشهورتان من أعرف أيام العرب، ديوان اندان

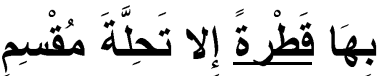

يبين الثاعر أن الإبل لم تذق من الماء إلا

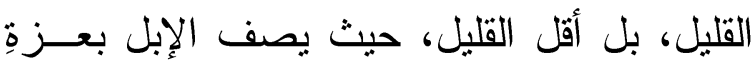

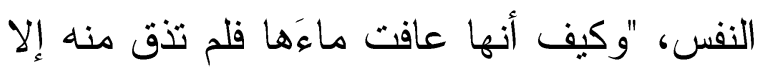

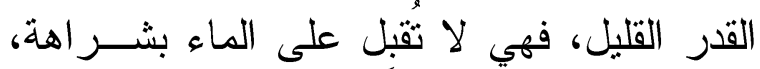

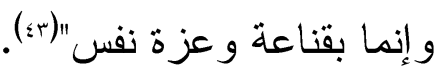

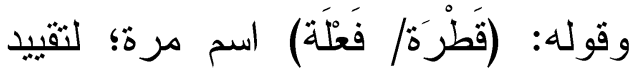

الحدث بمرة واحدة فقط، فالمصدر يُستعمل للقليل والكثير، أما اسم المرة فلا بستعمل إلا للمرة الواحدة، وفي هذا إثارة إلى اختلاف المعاني

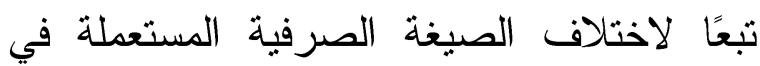
السياق، وقد آثر الثاعر استعمال صيغة المرة؛ لبيان عزة الخيل التي أَبَتْ شرب الماء إلا بمقدار

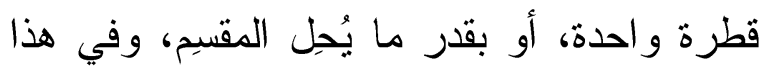

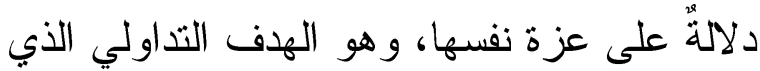
أر اده الثاعر من استعمال صيغة اسم المرة. وواسم المرة يتضمن معنى المصدر (الحدث)، إلا أنه يفترق عنه في حدوث الفعل مرة واحدة، والتعبير باسم المرة له دلالة صرفية تختلف عن دلالة التعبير بالمصدر، أو غيره من الصيخ الصرفية، ويتضح ذلك من خلال دور عناصر التداولية في إبراز المعنى المقصود. دور عناصر التداولية في بناء المعنى.

الماء في الإناء، ديوان طفيل الغنوي، صـهـ1، ( $(1 \mathrm{~V} / \mathrm{T})$ (آشعر طفيل الغنوي دراسة فنية، محمد أحمد عبد (ال). 
بُضفِي الحركةَ و الحيويةَ على النص، وكل فعـل من هذه الأفعال له بعـــ تــداولي فــي الـــص

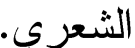

وفي هذه الأبيات يوجه الشاعرُ خطابًا إلى المتلقي فحواه وصف رحلة الظعائن، وقد

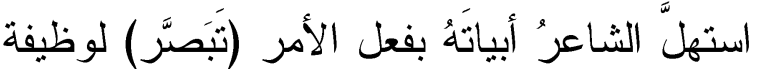
تداولية هي رغبة الثاعر في إنجاز (فعل) حدث) موجَّه إلى المتلقي للفت انتباهه إلى ما يُقال.

ففي هذه الأبيات يصف الثاعر' رحلةً الظعائن بالسرعة، دل على ذلك قوله: (ظعائن أبرقن)، فالظعائن قد سِرْنَ في عُجَالةٍ، و السرعة في المسير يناسبها السرعة حتى في الشرب؛ لذللك جاءت لفظة (شربْةَ) بصيغة اسم المرة في

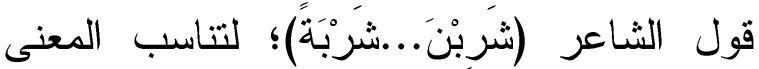
العام في هذه الأبيات التي تدور حول سرعة

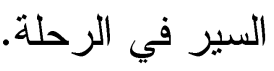

وقد استعمل الثاعر صيغة اسم المرة

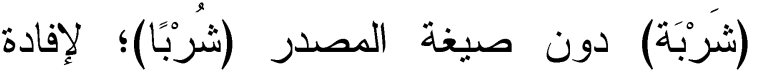
حدوث الفعل مرة واحدة، فكان هذا العدول رغبة في إرسال دلالاتٍ إلى المتلقي، منها: تحديد قدر

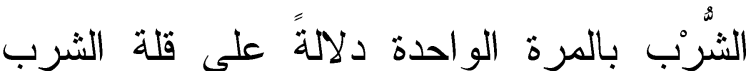
نظرًا لسر عة الرحيل. دور عناصر التداولية في بناء المعنى. أولًا: الإشاريات: استعمل الشاعر الفعل (شَربْنَ) مسندًا إلى نون النسوة العائد إلى الظعائن في الأبيات السابقة، ث جاءت الإشارة إلى المكان (عكاش، الهبابيد، الأحفى) بواسطة حرف الجر (الباء) دلالة على الالتصاق، أي: درور الرحلة
الإبل الماءَ، فلم تذق حتى أقل ما يُقََّّم من الماءٍ

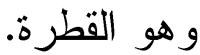
فصبغة (قَطْرَة) اسم مرة اقتضاها المعنى العام للبيت؛ لأن الشاعر يريد أن يبلغ (المتلقي) السامع) في خطاب تداولي إخباري أن الخيل لم تشرب الماءَ إلا بمقدار قطرة؛ دلالةً على قلة تتاولها الماء، فهذه الصيغة الصرفية أكثر فعالية في تأدية المعنى الذي يقصده الشاعر، وأبلغ تأثثرًا في أداء الوظيفة التواصلية، فقد طابقت

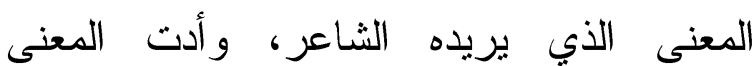

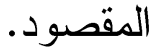

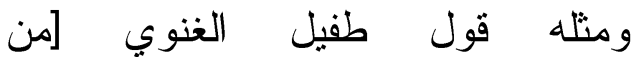

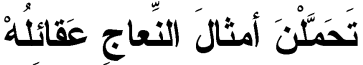

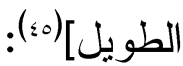
تَبَصَّ خليلي هل ترى من ظَعَائن ظعائنُ أبْرَقَنَ الخَرَيفَ وشِمِنْهَه وخِفْنَ الاهُمَامَ أن تُقَادَ قتابِلُهُ

$$
\text { على إثْر حيِّ لا يرى النَّْْْ طالعًا }
$$
من اللَّلَ إلَّاّ وهو بَادِ منازلنهُ

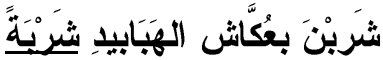

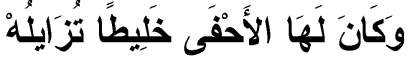

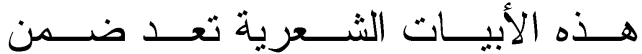

الإخباريات، وقد تعددت صيخ الأفعال بين الفعل الماضي (أبرقن، خفن، شربن) و الفعل المضار ع (ترى، تحملن، تقاد، تز ايلـــه)، و الفعــل الأمـــر

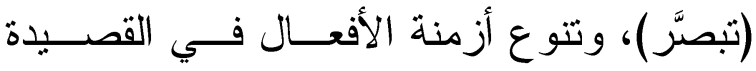
(0) شَرَبْنَ يعني الظَّعن، وعُكَّاش: مكان، و الهبابيد: موضع، والأحفى: بلد، وكان لها هذا البلد كالخليط وكان

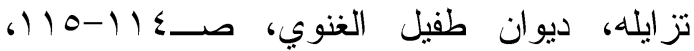
$\cdot(1 \cdot-V / V)$ 
المعدول إليها دون الصيغة المعدول عنها تخدم المعنى المطروح من قبل الثاعر في إطار من العناصر التذاولية التي تعين على إبراز مراد الثاعر و إيصال غرضه إلى المتلقي. (د)- العدول عن المصدر إلى اسم الهيئة. اسم الهيئة يصاغ من الفعل الثلاثي على الثى الثئه وزن (فِعَّْة) بكسر الفاء وسكون العين، والفرق بينه وبين اسم المرة في حركة الفاء، فإن كان

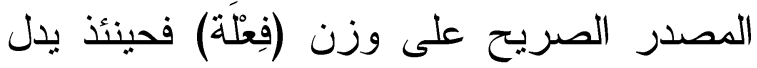

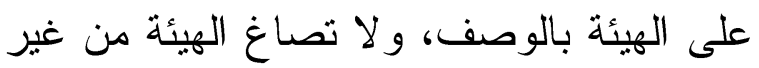
الثلاثي (ن) وقد ورد العدول عن المصدر إلى اسم الهيئة لوظائف تداولية في قول طفيل الغنوي [من البسيط] (2)

وردت في كتب اللغة بعض مصادر الهيئة من غير الثلاثي، ولكنها مصادر سماعية لا يُقاس علئها،

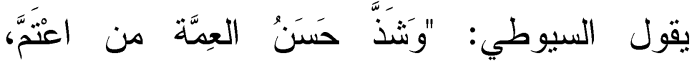

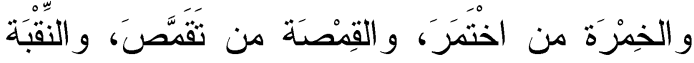

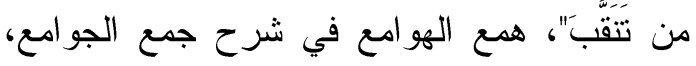
تأليف: الإمام جلال الدين عبد الرحمن بن أبي بكر التر السيوطي (ت / (9هـ)، تحقيق: أحمد شمس الدين الدين،

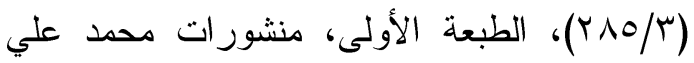
بيضون، دار الكتب العلمية، بيروت، لبنان،

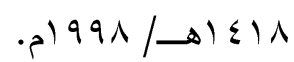

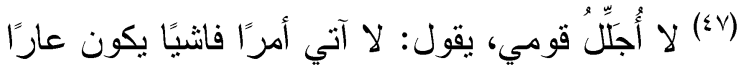

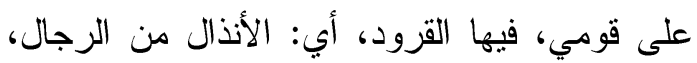

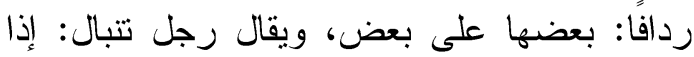

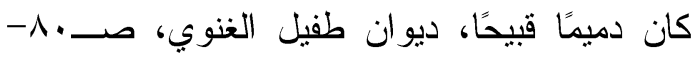

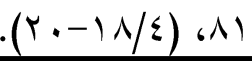

بهذه المواضع، ثم جاءت الإحالة الضميرية في (لها، تزايله) للإثشارة إلى اسم سابق في الكلام، فهي إحالة ضميرية سابقة، وجاءت صيغة المرة (شَرَبَة) بصيغة المفعول المطلق لترتبط بالفعل (شَرِبنْ) بعلاقة التحديد و التوكيد. ثانيًا: الافتر اض السابق: الظعائن في رحيل دائم دل على ذلك كثرة المواضع التي مرت عليها في رحلتها، مثل: (عكاش، الهبابيد، الأحفى، دمخ، .... ثالثًا: الاستلزام الحواري: الفكرة الرئيسة التي تتحدث عنها الأبيات (رحيل الظعائن) تستدعي الزئي صيغة اسم المرة (شَرْبَة) دون صيغة المصدر

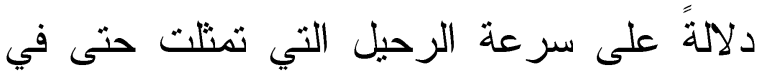
سرعة الثرب، فالاستلز ام الحواري أوجب على الرى لئل

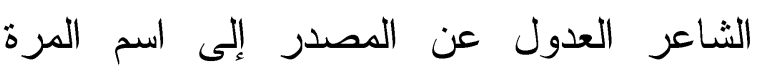
للالالة على سرعة رحيل الظعائن؛ فجاء

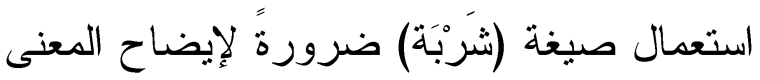

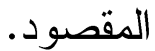

ررابعًا: الفعل الإنجازي: استعمل الثاعرُ الفعلَ الإخباري (شَربْنَ) مع صيغة اسم المرة (شَرْبَةً)؛ لتحديد مقدار تلك الثربة التي تتاسب سرعة الظعائن في رحلتها، وتتمنل قوة الفعل الإنجازي

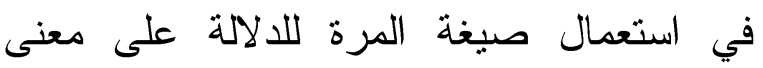
محدد أبرزته عناصر التذاولية تتمثل في قلة

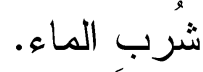

و العدول في الصيخ الصرفية يكثف عن دلالات التواصل بين طرفي الخطاب، وهذا ما نلمسه في عدول الثاعر عن صيغة المصدر إلى اسم المرة لمعانٍ دلالية موجودة في الصيغة 
وتوضح قيمة الاستعمال التداولي للصيغة

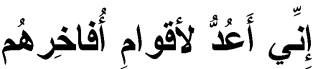

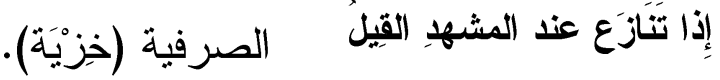

ثانيًا: الافتز اض السابق: الثاعر في موضع المفاخرة بقومه؛ لذلك يؤكد أنه لا يُخزي قومه النهاع

ثالثًا: الاستلزام الحواري: جاء عدول الثاعر عن صيغة المصدر (خزني) إلى صيغة الهيئة (خِزيَّة)؛ لتعظيم قومه وتمجيدهم، وقد أكد إلى الثاعر على ذلك بوصف الخزي بجملة: (فيهًَا القُرُودُ ردَافًا و الآتَّابيلُ). رابعًا: الفعل الإنجازي: تصدر الفعل الإخباري

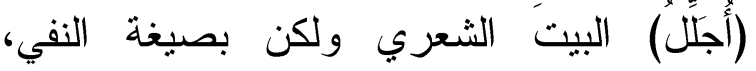
وتتمنل قوة الحدث الإنجازي في استعمال الثاعر

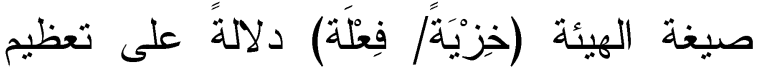
الثاعر لقومه.

واسم الهيئة يتضمن يعى المصدر

(الحدث)، غير أنه يفترق عنه في بيان الهيئة التي اتصف بها الحدث، والتعبير باسم الهيئة له دلالة صرفية تختلف عن دلالة التعبير بالمصدر؛ لذلك لجأ الشاعر إلى استعمال اسم الهيئة لوظائف تداولية في سياق الخطاب الشعري. (هـ)- العدول عن دلالة اسم الفاعل إلى دلالة الصفة المشبهة.

اسم الفاعل وصف مشتق من الفعل للالالة على من قام به على وجه الحدوث لا الثبوت، أما الصفة المشبهة فهي وصف مشتق من الفعل اللازم للالالة على معنى ثابت في

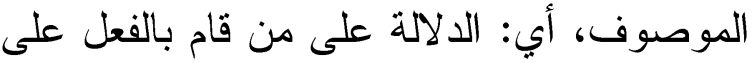

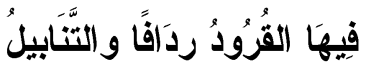

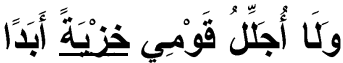

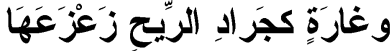

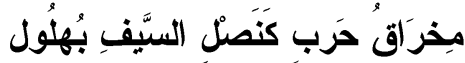

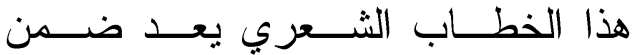

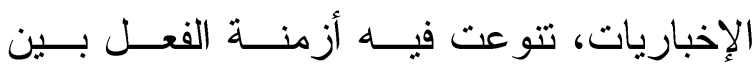

الماضي و المضار ع، وكل فعل من هذه الأفحسال له بعد تداولي خاص به في الاستعمال، وتـأتي هذه الأبيات في سياق افتخار الثاعر بقومه.

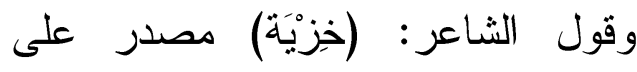
وزن (فِعَلَة)؛ لبيان هيئة حدوث الفعل، وقد استعمل الثاعر هذه (اللفظة/ الصيغة) في سياقها التداولي؛ لبيان الهيئة التي يتصف بهاعل الحدث، فهي تُعطي قيمةً تداولية في سياقها الثعري، لئية وهو تعظيم الثناعر لقومه وعدم خزيه لهم، فالثاعر يريد أن يضيف معنى جديدًا باسم الهيئة لا تضيفه صيغة المصدر، ويتضح ذلك من خلال دور عناصر التداولية في بناء المعنى. دور عناصر التداولية في بناء المعنى.

أولًَ: الإشاريات: الضمير المستتر في جملة (وكَا

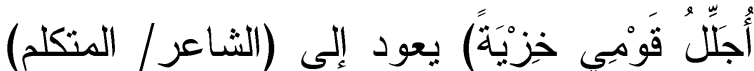
فهي إحالة خارجية تربط بين المتكلم والنص، و الضمير في شبه الجملة (فيها) يعود إلى اسم الهيئة (خِيَّة)، وجملة (فيها القرود) في محل نصب نعت لاسم الهيئة، وقد ربطت الواو العاطفة بين لفظتي (القرود) و (التنابل)، ... هذه العناصر الإشارية تربط بين أجزاء النص،

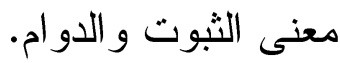




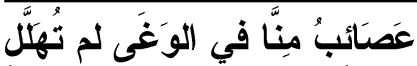

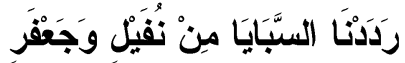

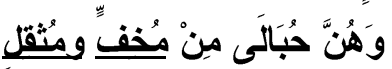

بَعِيِ حِلال راجَتَتْهُ مُجَفَفَل

ورَاكِضَةِ ما تَستَجنُّ بجنَّة

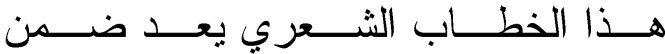

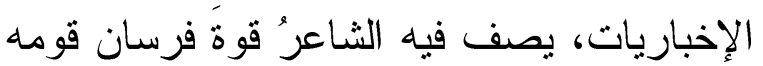

وشجاعتهم، وقد استحضر الشاعر فـي خطابــه

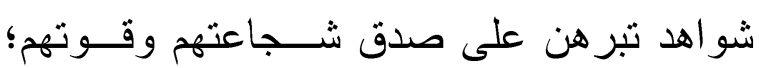
فكثرث الأفعال التي تدل على الحركة، وتضفي الحيويةً على نص القصبدة.

حيث تزخر هذه الأبيات الشعرية

بمجموعة من الأفعال على اختلاف أزمنتها ما بين الماضي (مسكم، منعنا، دعانا، رأى، صرع،

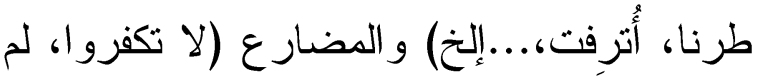
تعبل، لم تهلل)، و الأمر (أثتوا، اركبوا)، وتتوع الأفعال له أبعاد تداولية في بنية الخطاب الشعري، فالماضي يفبد التقريز، و المضار ع يدل على التجدد، و الأمر يفيد طلب حدوث شيء ما، وتتسق كثرة الأفعال الماضية مع السرد القصصي في الأبيات.

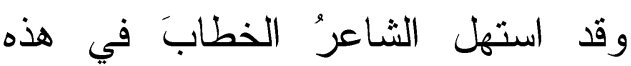
الأبيات بالنداء المحذوف الأداة (بني جعفر) دلالةً على قرب هؤلاء القوم منه، واستعمل الشاعر أسلوب النهي (لا تكفروا) لغرض تداولي، وهو إثعار بني جعفر بفضل قومه (قبيلة غني) في الذودِ عن حياضِيهِ ورد سباياهم. وقد غلب ورود الجمل الخبرية على الجمل الإنشائية، وهذا يتتاسب مع الغرض ولئ التداولي الذي يقصده الشاعر، وهو بيان شجاعة

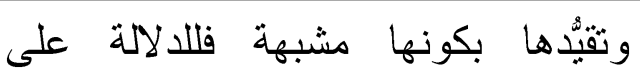

مشابهتها لاسم الفاعل، غير أن الفرق بينهما أن الصفة المشبهة تدل على ثبوت المعنى، واسم الفاعل يدل على حدوث المعنى وتجدده؛ لذلك فإنه يُعدل إلى الصفة المشبهة عند إرادة معنى الثبوت، ويُعدل إلى اسم الفاعل عند إر ادة معنى

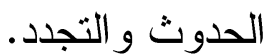

وقد جاءت صبغة اسم الفاعل بدلالة

الصفة المشبهة (اتصاف الذات بالحدث على وجه الثبوت) في قول طفيل الغنوي [من الطويل](مء):

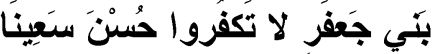

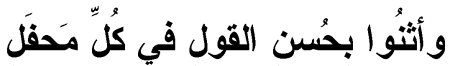

ولا تَكَرُوا في النَّائبَات بلاعَنا

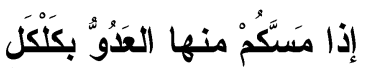

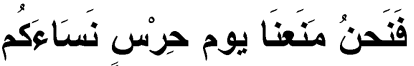

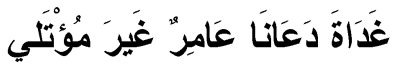

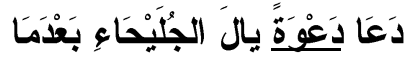

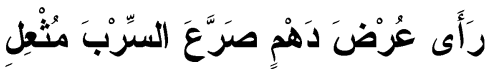

فقال اركَكَوْ أنتُم حماةُ لمثِلِها فَطِرنَا إلى مقصُورَة لم تُعبَّل

طِوالُ الأنَّابي أُترفَتَ وهي جَونَةْ

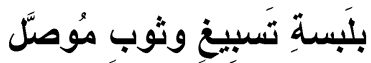

فجاءت بفُرستان الصَّباح عَوَابسًا

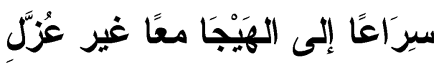
فأحمَشَ أولاهُمُ وألحَقَ سِرَِهُمْ فَوَ ارسنُ مِنَّا بالقَتا المُتَنَخَّل

فَحَامَى مُحَامِينا وطَرَّتَ عَيَنْهُم (الجليحاء: شعار لهم كانوا يعرفون فيه، صرَّع

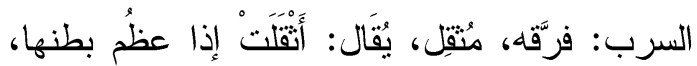

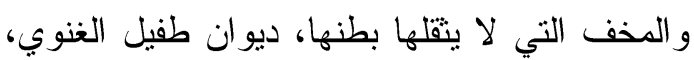
ص- 
وتأتي قوة الفعل الإنجازي من استعمال

صيغة المصدر (دعوة) مع صيغة فعله (دعا)؛

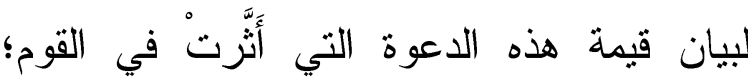
فتجمََُّو ا بسرعة البرق، وقد استهل الثاعر البيت لهان بصيغة الفعل الماضي للتقريز، ثم أكد خطابه بصيغة (المصدر/ المفعول المطلق)؛ لإشعار المتلقي بقوة تأثير هذه الدعوة في نفوس أهل قبيلته، و هذا ما يستدعيه الاستلز ام الحواري بين

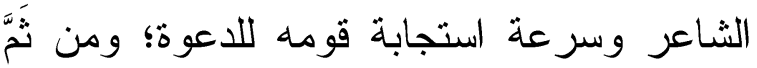
تتضح قيمة التداولية في إبراز معنى الصيغة الصرفية في سياق استعمالها في النص الثعري. ثم استعمل الثاعر صيغتي اسم الفاعل

(مُخفِفٍ ومُتُقلِ) بدلالة الصفة المشبهة (دلالة الثبوت)، أي: ثبوت نسبة الحدث الذي تتضمنه إلى موصوفها، وجاء التفصيل في الصيغتين بعد الإجمال في لفظة (حبالى) لغرض تداولي، وهو بيان الثاعر قوة قومه في رد جميع السبايا دون

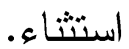

\section{دور عناصر التداولية في بناء المغنى.}

تتضافر عناصر التذاولية في إبراز

معنى الصيغة الصرفية من خلال السياق، فقد

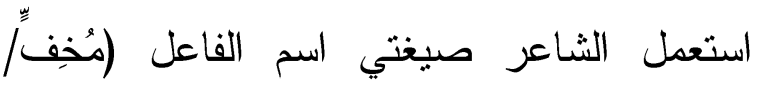
مُتقِل) لا على سبيل التجدد، و إنما على سبيل الثبات، ونوضح ذلك من خلال عناصر التداولية:

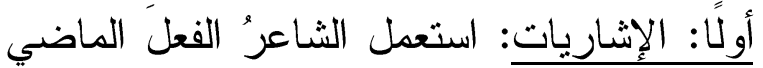

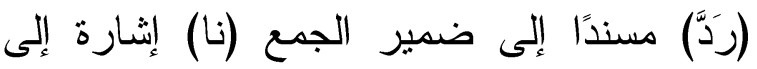

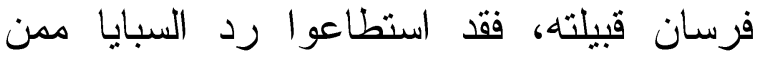

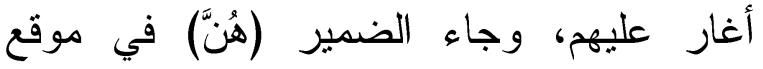
الابنداء؛ إثارة إلى السبايا النساء، و التركيب
قومه، وسرعتهم لنجدة المستغيث بهم، و هذا ما يجعل النص يتسم بالحيوية، ويحقق الهدف

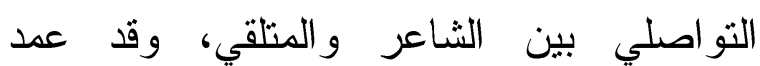
الثاعر في خطابه إلى أسلوب الحوار (المحاورة) تحقيقًا للهدف التواصلي بينه وبين المتلقي، حيث برتكز الحوار على غاية تواصلية هدفها الثداولي إظهار الثاعر سرعة نجدة قومه بله

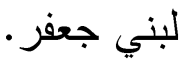

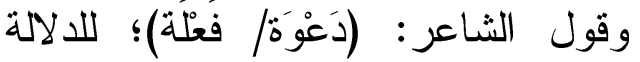
على اسم المرة، رغم أن التاء فيها تدخل في تشكيل بنية الصيغة المصدرية، و لا تُكسيب الكلمةً

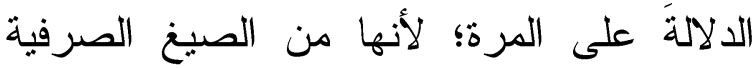
الملبسة بين المصدر واسم المرة؛ ولذا لزم وجود قرينة وصفية بكلمة (واحدة)، أو قيام قرينة في السياق بتحديد دلالة الكلمة على المرة، وقد تطلب السياق هنا سرعة استجابة القوم لهذه الدعوة السريعة التي لا تحتمل التكرار أو لأهن

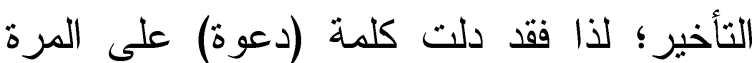

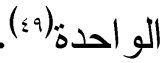

فالحوار يعبر عن سرعة استجابة القوم،

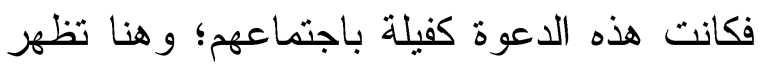
قيمة التداولية في بيان نوع الصيغة الصرفية من فئن

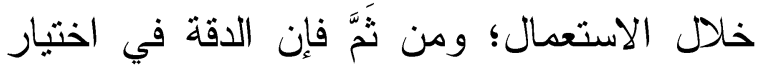
الصيغة الصرفية لها أثر ها البالغ في أداء المعنى الذي يقصد الثاعر إيصاله إلى المتلقي للتعبير عن سرعة استجابة قومه لتلك الدعوة.

(49) انظر: المثتقات في الأسفار الأدبية وديوان طفيل

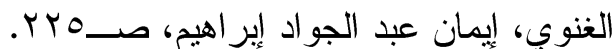


ويطرد مجيء اسم الفاعل بمعنى الصفة

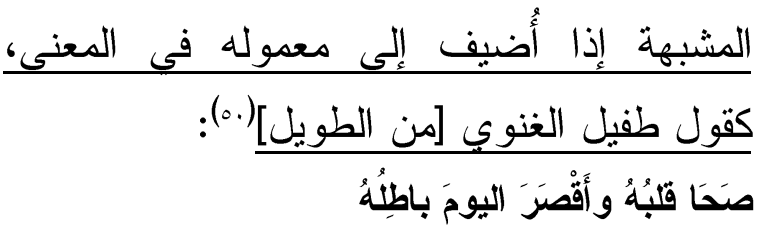
وأنكَرَهُ مِمَّا استَفَادَ حلانُلُهُ

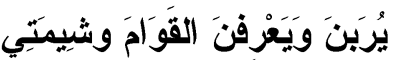

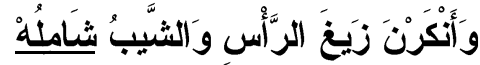

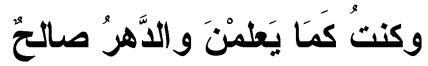

كصدر الَيَماني أخلَصتُهُ صَيَاقُكْهُ

وأصبحتُ قا عنفتُ بالجهل أهنَةُ

وعُرِيّ أفر اسُ الصبّبا ورَوَاحِّهُ

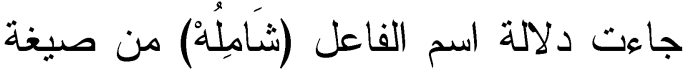

(فَاعِل) التي تدل على الذات المتصفة بالحــدث (وهو الرأس)، ليس على سبيل الحدوث و التجدد

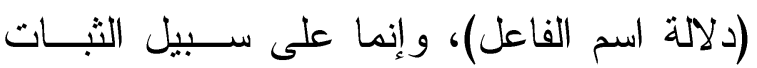

(دلالة الصفة المشبهة)، أي: ثبوت نسبة الحدث

الذي تتضمنه إلى موصوفها، و هو شمول شــيب

الرأس، ثم من دلالة بنية الفعل المشتق منه اسم الفاعل (شَمَلَ) (10).

دور عناصر التداولية في بناء المعنى. أولًا: الإشاريات: بدأ الثاعر البيت الثاني بفعل إخباري مسند إلى نون النسوة (يُرَبنَ) إثشارة إلى لفظ (حلائله) في البيت الأول، ثم عطف عليه الفعل الإخباري (يَعْرِنَ)، وقد تصدر الشطر

(0.) القوام: الثطاط، و الثيمة: الطبيعة، زيغ الرأس:

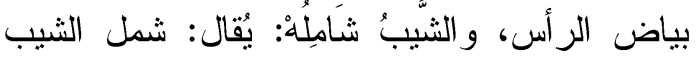
الر أس: إذا غطاه، يُرَبْنَ: يعني الحلائل، ديو ان طفيل

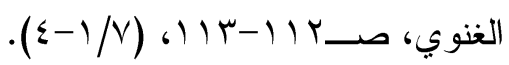

(10) انظر: المشتقات في الأسفار الأدبية وديوان طفيل

الغنوي، إيمان عبد الجو اد إبر اهيم، صـــ1 II.
الاسمي (هُنَّ حُبَالىى) في محل نصب حال لــــ

(السبايا)، هذه الإشاريات تربط أجزاء التركيب

مع بعضها.

ثانيًا: الافتر اض السابق: الشاعر في موضع المفاخرة بأهله وقبيلته الذين ردوا السبايا لبني جعفر وثأروا لهم؛ ولذلك جاء الحوار باستعمال

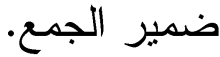
ثالثًا: الاستلز ام الحواري: استعمل الشاعر اسم

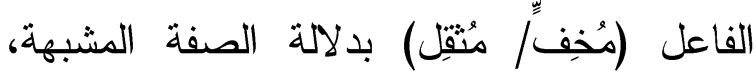
فالحُبَالى يكون حملَهُنَّ خفيفًا ثم ثقيلًا، وقد أشَار

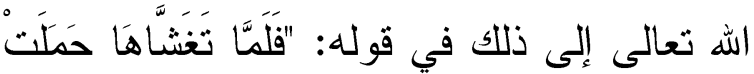

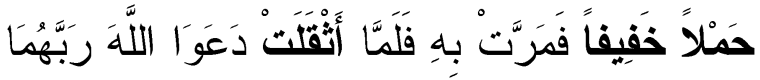

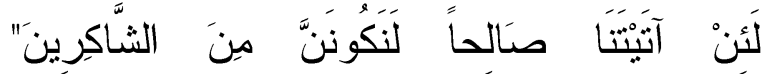
[الأعر اف:1 1 1]، فالاستلز ام الحواري قد فرض مين على الثاعر استعمال الصيغتين بدلالة الثبات (الصفة المشبهة).

رابعًا: الفعل الإنجازي: تأني قوة الحدث الإنجازي من لفظة (حبالى) التي فسرها الشاعر

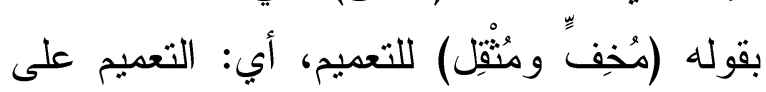
كل النساء الحبالى، فاستعمل الصبغتين لإبراز قصده في إطار من عناصر التذاولية.

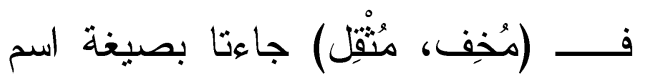
الفاعل (من غير الثلاثي)، لكن المراد دلالة الصفة المشبهة، والتي من دلالاتها ثبوت الصفة في موصوفها، وهو المعنى الأبلغ تداوليَّا لتضمنه دلالة القصدية التي يريدها (الثاعر/ المتكلم)، حيث قصد الشاعر ثبوت الصفة، وقامت التداولية بتأكيد هذا المعنى تحقيقًا للتو اصل بين عنصري

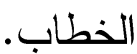


لسياق الذي وردت فيه الصيغة بناءً على قصد

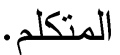

فقد حقت صيغة (شامله) بدلالة الصفة

المشبهة معنى يتفق مع غرض المتكلم وقصده،

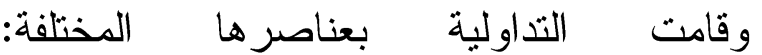
(الإشاريات، الافتراض السابق، الاستلزام الحواري، الفعل الإنجازي) بإبراز هذا المعنى وتأكيده، وتحقيق الترابط بين أركان الجملة تحقيقًا للتو اصل بين أطر اف الخطاب. وبذلك فان ظاهرة العدول الصرفي تزتبط ارتباطًا وثيقًا بالاستعمال التداولي، يكشف عن ذللك عدول الشاعر في الصيغ الصرفية لأهدافٍ تواصلية تداولية تحقيقًا للتو اصل بينه وبين المتلقي في دائرةٍ الخطاب الشعري.

المبحـث الثـاني : تعـدد الصـيخ الصـرفية للمعنى

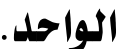

تتميز اللغة العربية بظاهرة تعدد الصيغ

الصرفية للمعنى الواحد، ويكون السياق هو الفيصل في تحديد دلالة الصيغة الصرفية، و الكثف عن قصد المتكلم من استعمال صيخة ما دون غيرها من الصيغ الصرفية في سياق

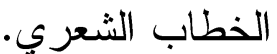

وتعدد الصيخ الصرفية للمعنى الواحد

يبين طبيعة الدلالة التي تحملها الصيخ المختلفة؛ وذلك بأن تشترك صيغتان أو أكثر في معنى واحد؛ فقد يجيء الشيء على (فَّلَّت) فيشرك

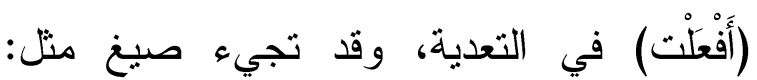

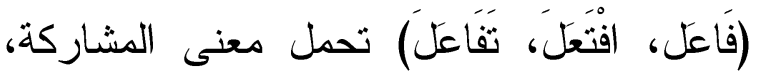

الثاني الفعل الإخباري (أَنْرَنْنَ) في صيخته الماضية مسندًا كذلك إلى نون النسوة العائدة إلى لفظ (حلائله). و الضمير في صيغة (شَامِلْهُ) معمول اسم الفاعل ومضاف إليه؛ لذلك جاء اسم الفاعل هنا بمعنى الصفة المشبهة دلالةً على الثبات و الدو ام، وقد عاد الضمير إلى لفظ سابق (الرأس)، وجملة (الثيب شامله) في محل نصب حال، وترتبط جملة الحال بصاحبها بالواو والضمير معًا، فالضمير المضاف إلى اسم الفاعل يربط جملة الحال بصاحبها دلالةً على أن الثيب خاص بالر أس دون غيرها وقد شملها؛ فغطدّى الشيبُ جميعَ الرأس على صفة الثبات و الدوام؛ وبذلك تؤدي الإشاريات وظيفة الربط بين أجز اء النص. ثانبًا: الافتر اض السابق: الشاعر يتحدث عن شيب الر أس. ثالثًا: الاستلزام الحواري: استلزم الحوار بيان شمول الثيب؛ فعدل الثاعر عن دلالة اسم الفاعل إلى دلالة الصفة المشبهة إثارةً إلى أن الشيب قد شمل كل الر أس. ررابعًا: الفعل الإنجازي: استعمل الشاعر صيغة اسم الفاعل (شامله) بمعنى الصفة المشبهة لإضافته إلى معدوله؛ فالثيب قد شمل الرأس على وجه الثبوت و الدو ام.

و القاعدة الصرفية تقتضي استعمال (شامل) اسمًا للفاعل؛ لأن كل صيغة صرفية لها معنى تؤديه، ولكن يحدث العدول لأهدافٍ تداولية؛ مما بعمق المعنى ناحية الاستعمال التداولي؛ فيتولد عن ذلك معنى يتتاسب مع 
المطاوعة في شعر طفيل الغنوي على النحو

1) - صبغة: (انفَعَلَ).

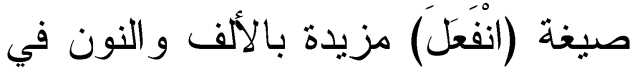

أول مبنى الصيغة، وتأتي هذه الصيغة الصرفية

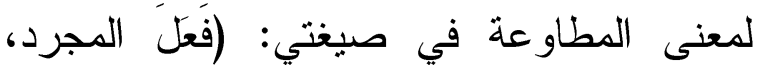

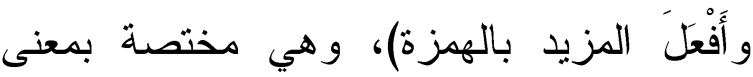
المطاو عة دون غير ها من المعاني الصرفية.

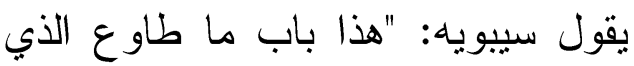

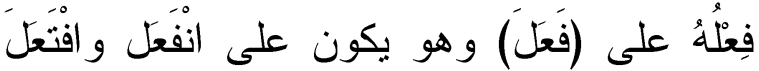

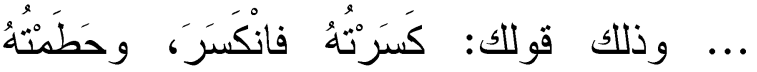

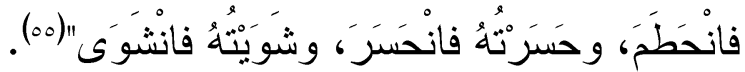

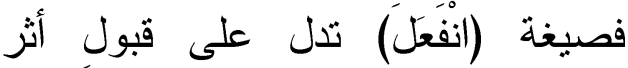
الفعل؛ ومن ثم يخلص معناها للمطاوعة، وهذه

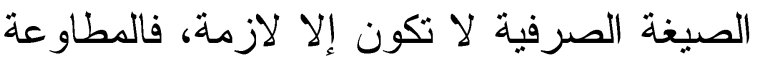
عكس التعدية، ومبنى الصيغة ومعناها ذو أثر شكلي ودلالي في دلالة التركيب، ويُتَّاول معنى ومنى دونى المطاوعة في دائرة الخطاب الثعري من خلال الصيغة الصرفية الدالة عليه.

وقد وردت صيغة (انْعَل) في شعر طفيل الغنوي للالالة على معنى المطاوعة في قوله [من الطويل] (ن):

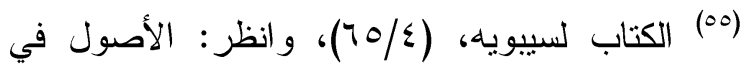

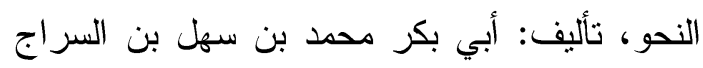

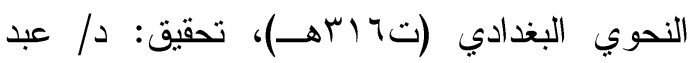

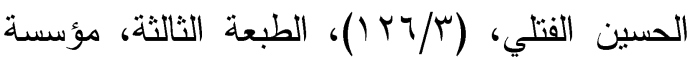

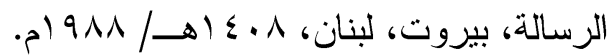

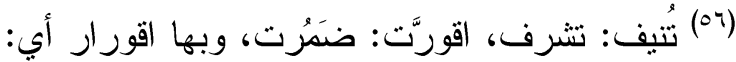
ضمور، القود: قيادها إلى العدو، هاديها: عنقها، ونها:
وفي معنى المطاوعة وردت عدة صيخ صرفية تشترك في الدلالة على معناها(م).

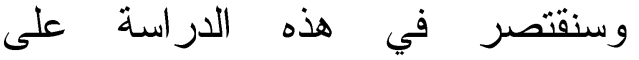
المطاوعة باعتبارها أحد المعاني التي تتعدد الصيخ الصرفية للالالة عليها في السياق التداولي

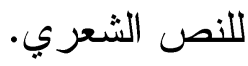

\section{تعلد الصيخ الصرفية في معنى المطاوعة.}

المطاوعة هي: قبول الأثر، أي: "تأثر

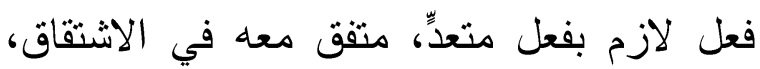

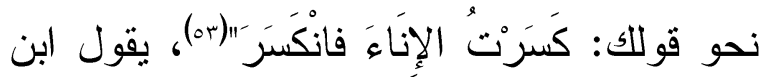

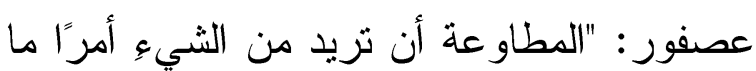

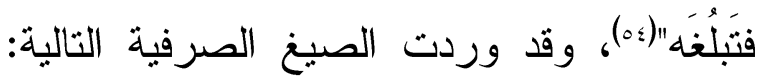

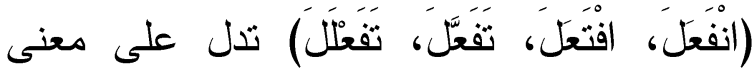

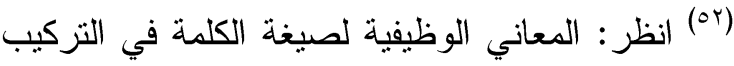

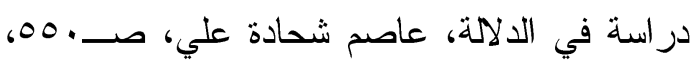

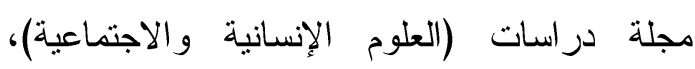

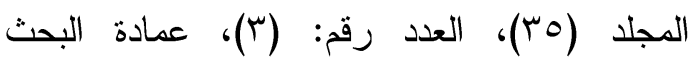

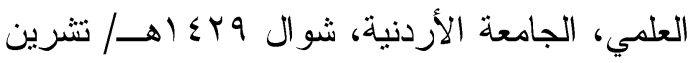

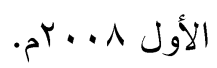

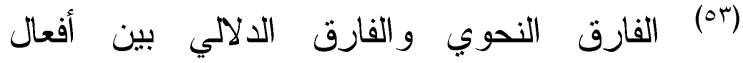

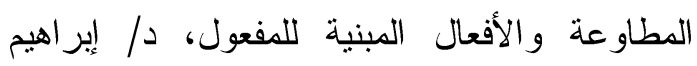

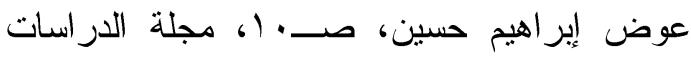

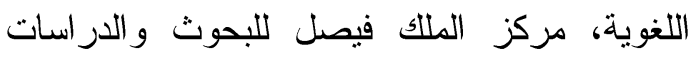

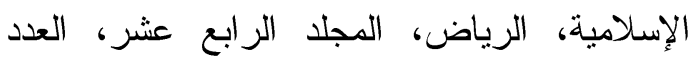

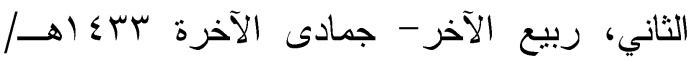

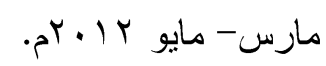

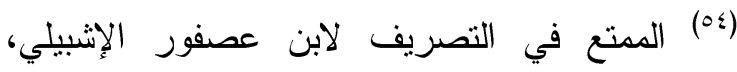

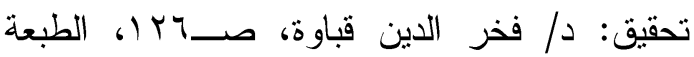
الأولى، مكتبة لبنان ناشرون، بيروت، لبنان، 
دور عناصر التداولية في بناء المعنى.

أولًا: الإشاريات: بدأ الشاعر البيت بالفعل المضار ع (تنيف) في سياق الأسلوب الثرطي؛ إثارة إلى الخيل، وتاء التأنبث الساكنة في

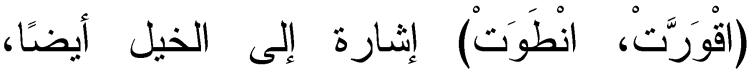
و الجملة الفعلية (يَهْرَ' الخَبِّ) في محل جر نعتٍ لـ (هادٍ)، وترتبط جملة النعت بالمنعوت بالضمير المستتر؛ وبذلك فإن الإشاريات عنصر من عناصر التداولية في إيضاح الفكرة وإيصالها إلى المتلقي. ثانيًا: الافتز اض السابق: انصياع الخيل لأوامر فارسها و انقيادها له.

ثالثًا: الاستلز ام الحواري: فرض الاستلز ام الحواري على الثاعر استعمال صيغة (انْطَوَى) انْفَكَ) للالالة على انصياع الإبل و انقبادها لأوامره، وقد قدم الثاعر فعل جواب الشرط (تِنيف) على فعل الشرط (اقْوَرَّتْ) للأهمبة. رابعًا: الفعل الإنجازي: استعمل الشاعر الأفعال الخبرية (تُنِفِ، اقْورَّتَ، انْطَوَتْ) في معرض حديثه عن الخيل، و الفعل (انْوَىَ) انفعل) يدل على المطاو عة وقبول أثز الفعل؛ دلالةً على تعدد محاسن الخيل، فهي طبِّعةٌ تتقاد إلى أمر فارسها وتتصاع له. و التحليل التداولي يوضتح لنا ما يقصد الشاعر إيصاله إلى (المتلقي/السامع) من خلال استعماله صيغة المطاوعة، والتي تذل على أن

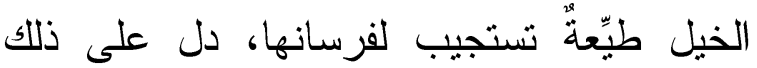
الفعل (انْطَوَتْ)، أي: أن الخيل طوت عُنَّها فانطوت، فالمطاوعة قد أبرزت قصدية المتكلم

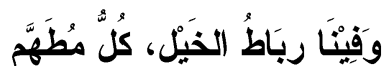

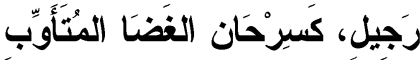

يُذِيقُ الأي يَعْلو على ظَهْز مَتْنِهِ

ظِلالَ خَذَارِيفِ، مِن الثَدَِّّ مُلْهب

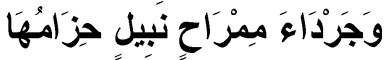

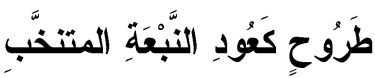

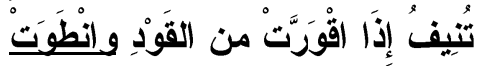

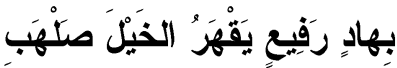

وَعُوْجَ كأَحْنَاء السنَ اء مطَتْ بِهَا

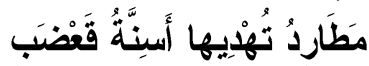

الخطاب الشعري في هذه الأبيات ينضـــوي

تحت تصنيف الإخباريات، وقد تراوحت الأفعال بين المضار ع (يذيق، يعلو، تتيف، يقهر، تهديها) و الماضي (اقورَّت، انطوت، مطت)، وكل فعـلـ من هذه الأفعال يحمل قوة إنجازية فـي ســياق الاستعمال النصي للقصيدة، وقد غلبـــ الجمــلـ الخبرية التقريرية على هذه الأبيات الشعرية.

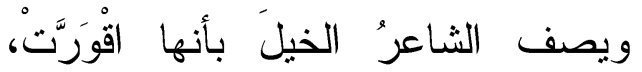

(أي: ضَتَرَتْ) بعد أن كانت سمينة؛ وذلك من كثرةِ خوضِيها المعارك، و الضمور صفة طيبة في الخيل تعطيها القوة والسرعة في حالة الكر

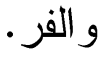

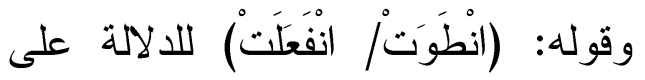

معنى المطاوعة، و لاشك أن المعنى الذي يقصده الثاعر هو الذي يستذعي هذه الصيخة الصرفية دون غيرها من الصيخ الأخرى لإبراز قصده.

الصلهب: الطويل، الرفيع: المرتفع، يقهر: يسبق، ديو ان طفيل الغنوي، صــ 


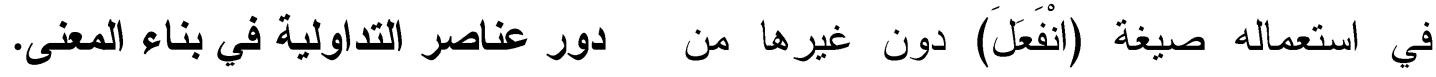

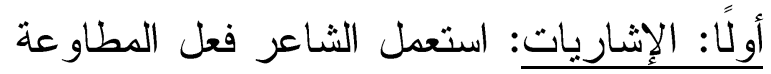

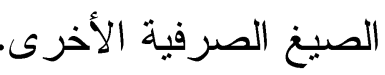

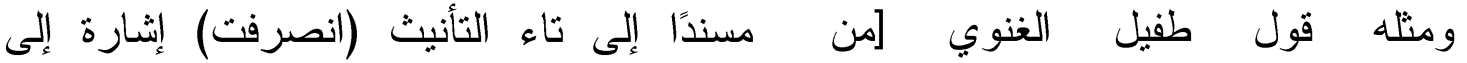

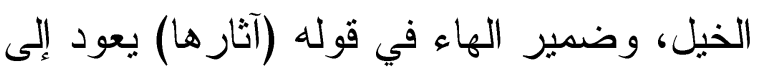
الخيل إثارة إلى صوت الحصى الذي يتقلب كلما جرت عليه الخيل؛ فيُحدِث صوتًا كالمؤلب. ثانيًا: الافتر اض السابق: الثاعر في حديثه عن فئن الخيل يصفها بكثرة خوضها المعارك.

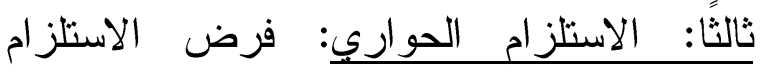
الحواري على الثاعر اختبار صيغة (انصرف)

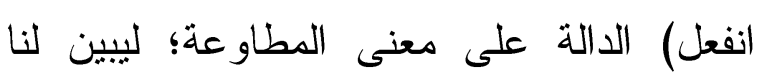

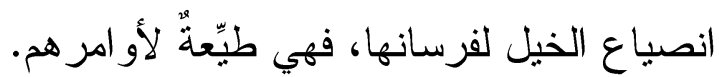

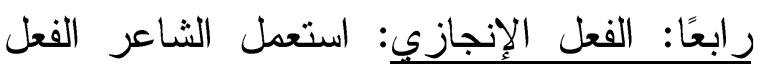
الإخباري (انصرفت) للالالة على معنى الإنى

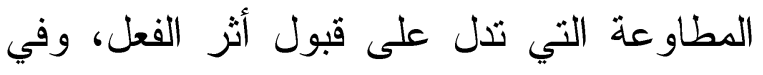

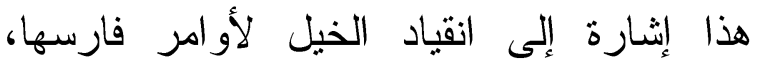

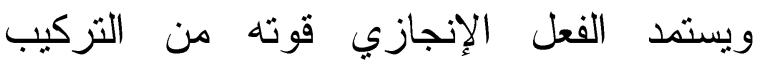

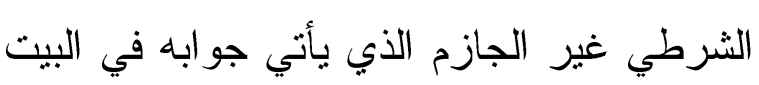

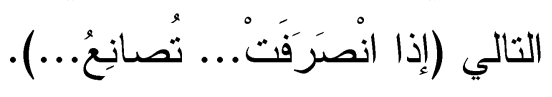
فقد اعتمد الثاعر أداة الثرط (إذا) التي لئهرن تستعمل لغير العاقل، وهي تتاسب حديث الثاعر عن الخيل، وتقيد تحقيق جواب الثرط لوجود

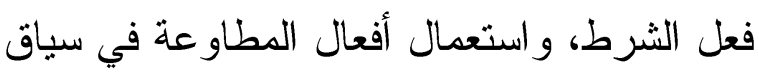
الأسلوب الثرطي وسيلة تداولية لإبراز قصدية المتكلم.

ثم يقول طفيل الغنوي [من الطويل](ه):

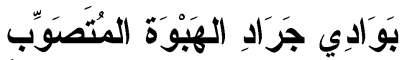

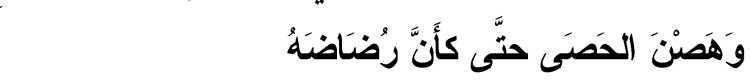

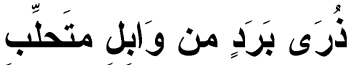

الطويل] [مان (م)

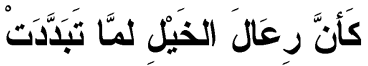

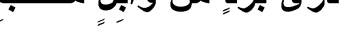

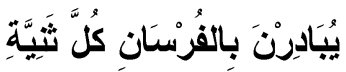
جُنُوحَا كَفُرَّاط القَطَا المُتَسَرِبِب

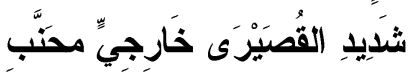

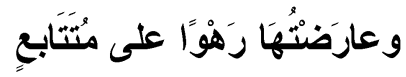
كأن على أعْرَافَفِهِ ولجََِامِهِ

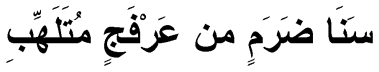
كأنَّ على أعطَافِهِه تَوْبَ مَائح

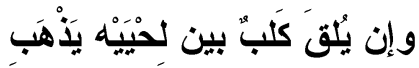

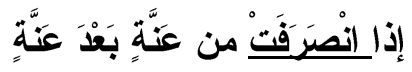

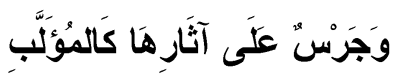

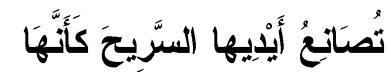

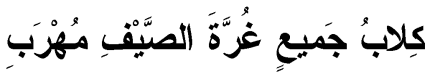
في هذه الأبيات يصف الثاعرُ الخيلَ بَأنها

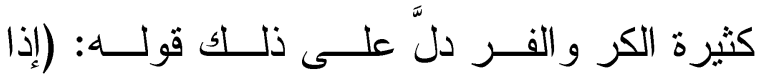

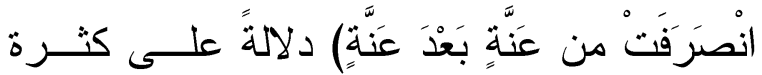
خوضها الحروب و المعارك، وقد اعتمد الثاعر على أسلوب التشبيه كوسيلة من وسائل الإقنــاع الحجاجي، والخيل في انطلاقها إلى ميدان القتال

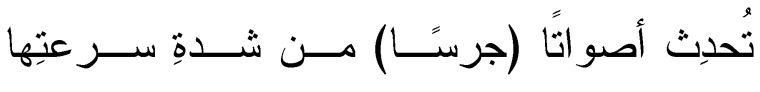

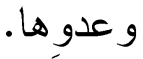

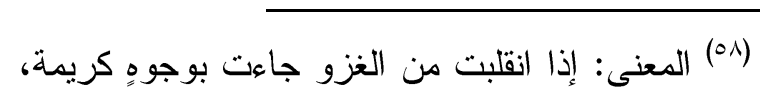

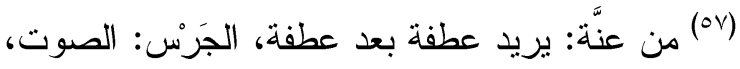
قال الأخش: انقلبت: رجعت الخيل من الغزو، أدت النغ

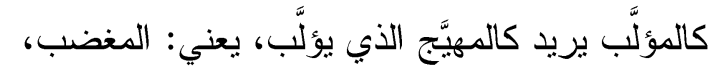

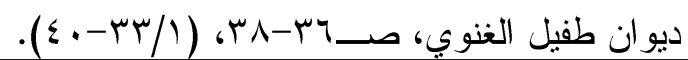


ثالثًا: الاستلز ام الحواري: الخطاب الثعري يدور

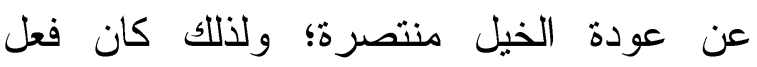

$$
\text { المطاو عة (انقلبت) بمعنى (عادت). }
$$

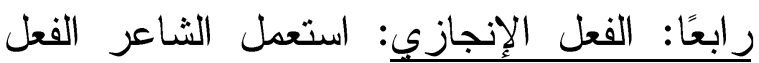
الإخباري (انْلَبَتْ) للالالة على معنى الإنى المطاو عة؛

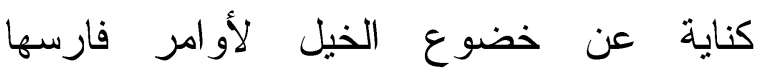
و انصياعها له، وتكمن قوة الفعل الإنجازي في

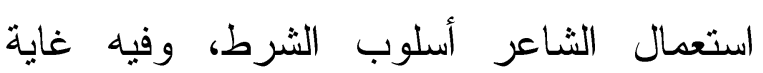
تداولية وهي أن الخيل حينما تعود من الحرب تعود بوجوه كريمة (كناية عن الفرسان)، وكل فعل إنجازي له غاية نداولية في سياق النص.

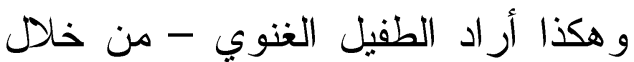
الأبيات السابقة - أن يوضح لنا انصياع الخيل

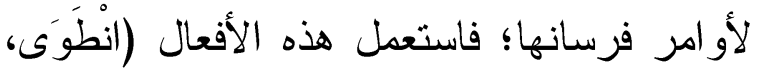

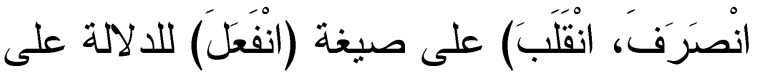

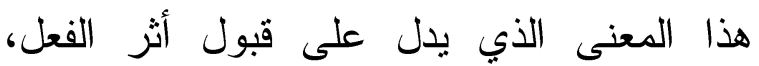

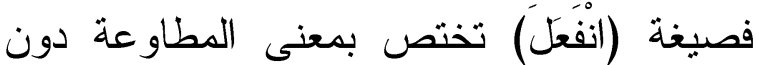
غير ها من المعاني الصرفية، وهو ما أبرزته هذه

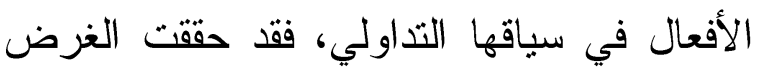
الإنجازي في بيان مطاوعة الإبل لأوامر

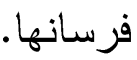

وفي إطار الافتراض السابق - كأحد

عناصر التداولية - نفترض أن كل فعل من هذه الأفعال قبله فعل من مادته مسند إلى الفاعل وهو (الفارس)، ثم جاء الثاعر بفعل المطاوعة مسندًا إلى تاء التأنيث إثارة إلى الخيل على الثى النحو

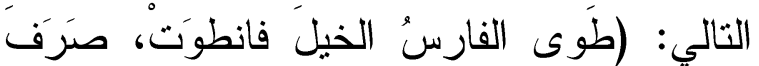

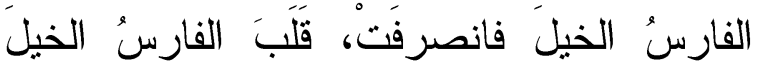

إِذََا إنقَلَبَتِ أَدَتَتْ وُجُوهُا كَرِيمَةً

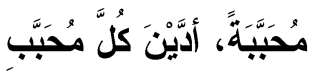

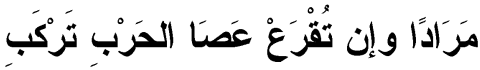

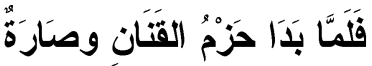

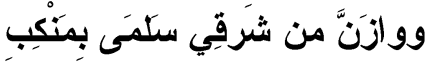

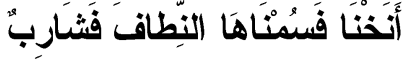
قََلَلاً وآبَ صَدَّ عن كُلِّ مَشْرَبِ

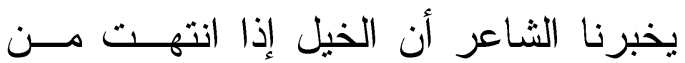
الغزو و المعركة رجعت بوجوه كريمة منتصــرة

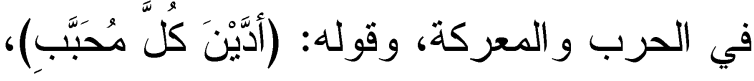
أي: حملن على ظهور هنَّ كل فارس، كناية عن هؤلاء الفرسان المنتصرين الذين عادوا بالنصر المؤزَّر وبالأسرى المكبَّلين في القيود. دور عناصر التذاولية في بناء المعنى. أولًا: الإشاريات: استعمل الثاعرُ الفعلَ الدال

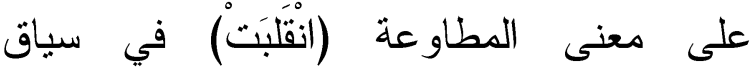
الأسلوب الشرطي، وجاء جواب الشرط فعلًا

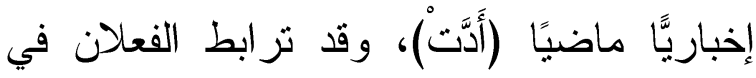
سياقهما التركيبي من خلال ترابط فعل الشرط بجوابه، وجاءت تاء التأنيث في فعلي الثرط وجوابه إثـارة إلى الخيل، و العنصر الإثاري (نون النسوة) في التركيب الفعلي (أَدَّنْن) إنثارة الإنداري إلى النى النيل أيضًا. ثانيًا: الافتر اض السابق: يتحدث الثاعر في هذه

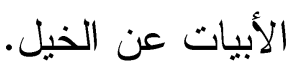

وجوهاً كريمة، بعني: فرسانها، محبية: بعني الخيل،

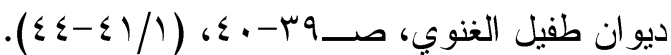


وقد وردت هذه الصيغة الصرفية بمعنى

المطاوعة في قول طفيل الغنوي [من

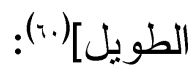

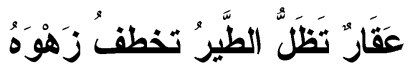

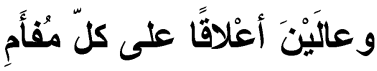

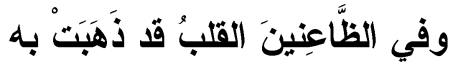

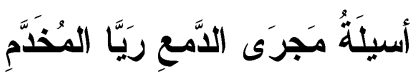

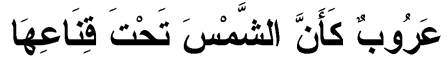

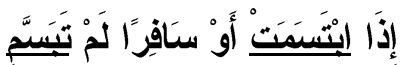

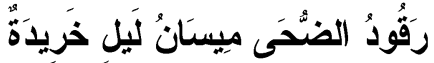

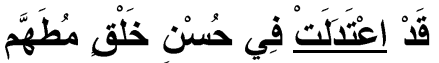

$$
\text { أصاح ترى بَرقًا أُريكَ وميضَنَة }
$$

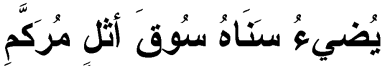

يتغزل الثاعر بمحبوبته في هذه الأبيـات،

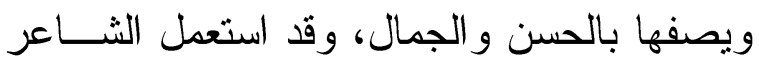

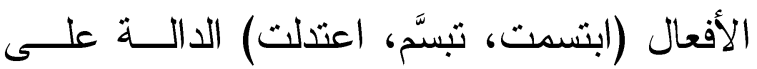

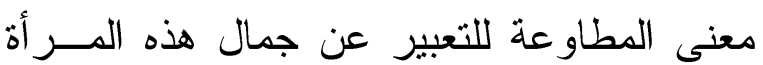

$$
\text { وحسن طلعتها. }
$$

و الاعتدال يفيد التتاسق والتوازن، فهي

سمينة حين تحسُن السمنة، ورقيقة حين تحسُن

الرقة، هذا الاعتدال وجهه الثاعر بالحرف (في)

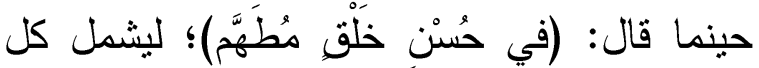

يعيش الموصلي (ت بـآهـ)، تقديم: د/ إميل بديع

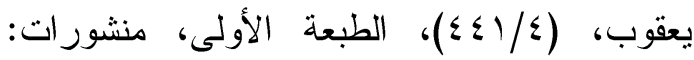

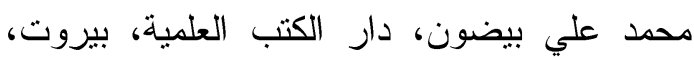

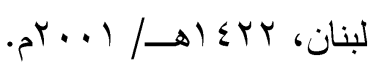

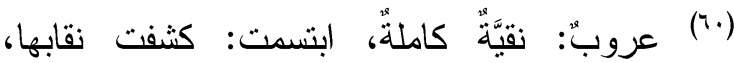

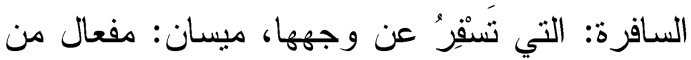

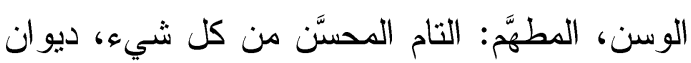

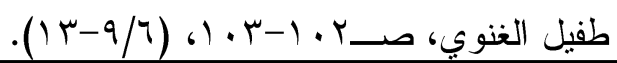

أما قوة الحدث الإنجازي في هذه الأفعال

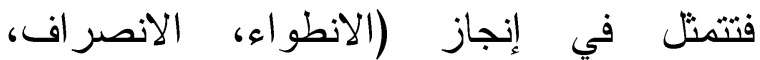
الانقلاب) بورودها على صيغة (انْعَل) الدالة على معنى المطاوعة، ولو لا ذلك ما استطاعت الخيل مواصلة القتال في المعركة، كما يستمد الحدث الإنجازي قوته من بنية التركيب الثرطي غير الجازم الذي وردت فيه (إذا انطوت/ إذا انصرفت/ إذا انقلبت)؛ لبيان هيئة الحدث، فاستعمال هذه الأفعال بصيغة المطاو عة يدل على الي النيان

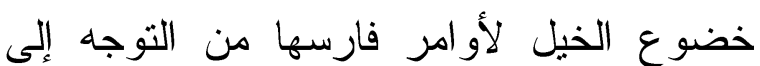
الحرب أو العودة منها.

ومن خلال التحليل التداولي للأبيات السابقة نتوصل إلى أن قصدية (المتكلم/ الثاعر) إخبار المتلقي بقوة الخيل وقبولها أوامر فارسها و انصياعها له، وإن ورود أفعال المطاوعة (انطوت، انصرفت، انقلبت) بهذا الترتيب له غرض تداولي يسهر في ترابط الأحداث

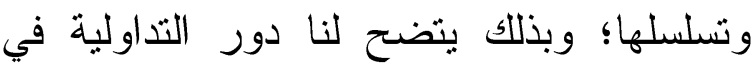
إبر از معنى المطاو عة في صيغة (انْفَلَ)َ).

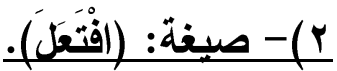

تأتي صيغة (افتْعَلَ) للمطاو عة؛ فنشارك حينئذ صيغة (انَْْلَ) في معناها، يقول سيبويها:

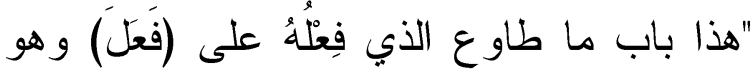

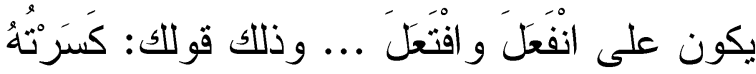

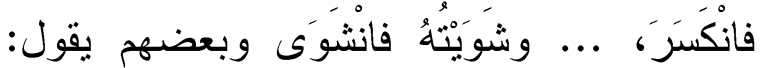

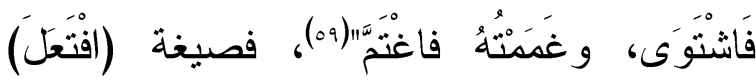

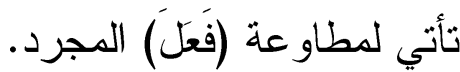
(09) الكتاب لسيبويه، (؟/70)، و انظر : شرح الدفصل اللزمخشري، تأليف: أبي البقاء بعيش بن علي بن بن الني 


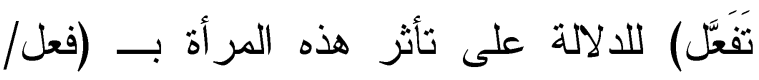

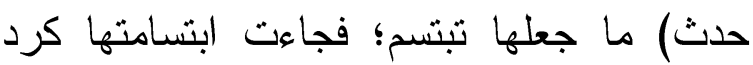
فعل لمثير قبلها، كما يدل فعل المطاوعة

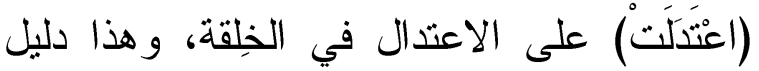
حسنها وجمالها.

وجاء الفعلان (ابتسمت، تبسَّم) في سياق

الأسلوب الثرطي غير الجازم؛ فاستعملهما الشاعر كفعلي للشرط دلالةً على حسن جمال المرأة التي تبدو كالثمس في جمالها، ثم جاء

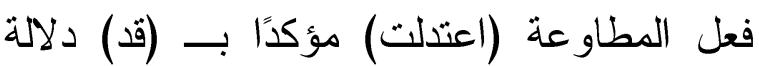
على حسن خلقتها التامة، وهذا دليل الكمال على اعلى لهال جمالها.

وقد قَم الثاعرُ جملةَ جواب الثرط

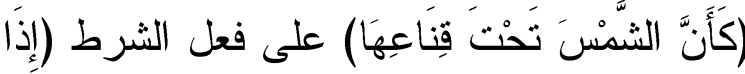

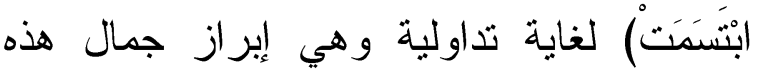
المرأة، فالثاعر يسعى من خلال خطابه الثعري واستعماله صيغ المطاوعة إلى إفادة المتلقي بجمال هذه المرأة وحسن ابتسامتها، و هذا هو الغرض الإنجازي من استعمال أفعال المطاوعة في هذا السياق. r) بريغة (تَفَلَّل).

تأتي صيغة (تَفَّلَ) لمطاو عة (فَعَلَ) المزيد بالتضعيف، يقول ابن جني: "أما (تَفَّلَّتُ)

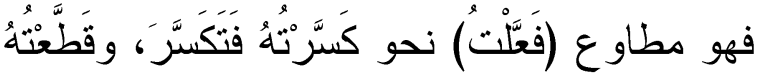

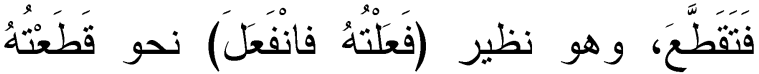

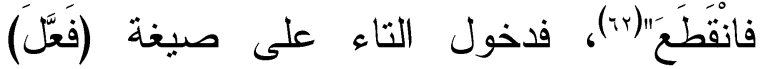

(rr) المنصف شرح الإمام أبي الفتح عثمان بن جني لكتاب التصريف للإمام أبي عثمان المازني، تحقيق:

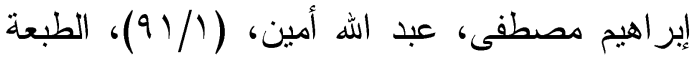

عضو من أعضاء الظاعنة، فالثاعر يبدو وكأنه ينحت تمثالًا بار ع الجمال (1) و استعمال الثاعر أفعال (ابتسمت، تبسَّم، اعندلت) بمعنى المطاوعة يبرز قصدية المتكلم في إطار عناصر التداولية للتعبير عن جمال هذه

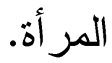
دور عناصر التداولية في بناء المعنى.

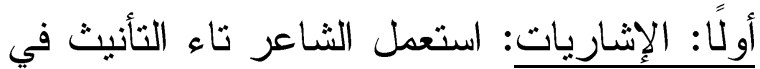
الأفعال (ذهبت، ابتسمت، اعتدلت) إثارة إلى ألى المرأة التي يتحدث عن حسنها وجمالها، و الضمير المستتر في هذه التراكيب الفعلية عائد أيضًا إلى المر أة التي يتغزل فيها الثاعر، كذلك التك

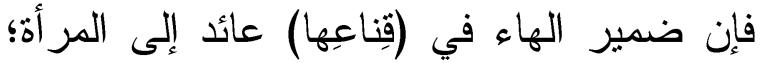
وبذلك فإن الإشاريات عنصر من عناصر

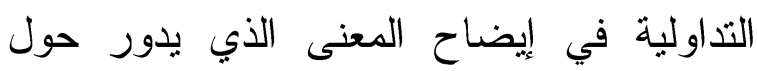
جمال هذه المرأة وحسنها، والذي يريد الثاعر إيصاله إلى المتلقي. ثانيًا: الافتراض السابق: الثاعر يصف جمال

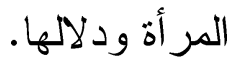
ثالثًا: الاستلزام الحواريا

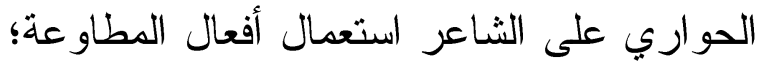
لإبراز أثر الابتسام على وجه هذه المرأة بجمال

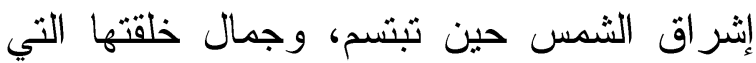
اعندلت، فكانها لوحة إبداعية قد رُسيدت بريشة

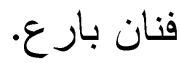

رِابعًا: الفعل الإنجازي: استعمل الثشاعر أفعال

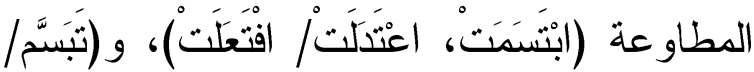

(اי) انظر: بلاغة النص، د/ جميل عبد المجيد، 


\section{دور عناصر التداولية في بناء المعنح.}

أولًا: الإشاريات: بدأ الثاعر البيت الأخير بالفعل الناسخ (كان) مسندًا إلى ضمير الجمع (نا) إثـارة إلى أهل قبيلته، وقد جاء الفعل (اغتقَتَّت) مسندًا إلى تاء التانيث إثارةً إلى الخيل، ثم جاء اءثل الفعل (تجرَّد) مسندًا إلى اسم ظاهر ، وقد تر ابط الفعلان

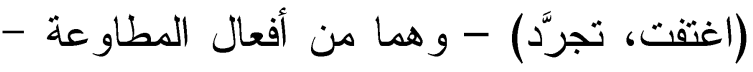
من خلال تز ابط فعل الشرط بجو ابه. ثانيًا: الافتر اض السابق: الشاعر يتحدث عن

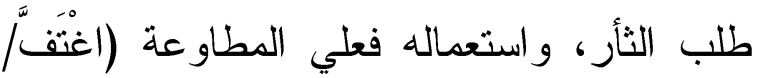

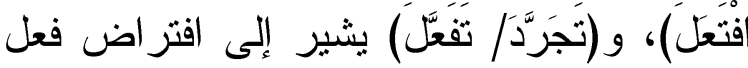
سابق من مادة الفعل على فعل المطاوعة يستجيب الفعل لأثره على النحو التالي: (غًَا الربيعُ الخيل فاغتفت)، (جرَّدَ اغتفاءُ الخيل

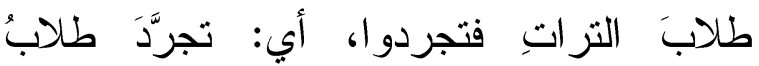

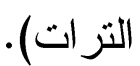

ثالثًا: الاستلز ام الحواري: حينما أصابت الخيلَ

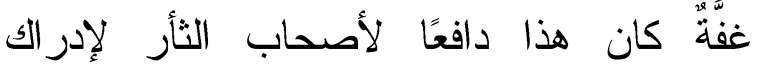
ثأرهم؛ فتأهبو الينئذٍ لطلب الثأر؛ فجاء تجردهم وتأهبهم كرد فعل لحالة استرخاء الخيل.

رابعًا: الفعل الإنجازي: استعمل الشاعرٌ الفعل

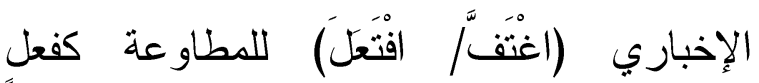
للشرط، ثُ جاء فعل جو اب الشرط (تَجَرَّدَ تَفَعَلَ) بمعنى المطاوعة أيضًا للالالة على قبول أثز الفعل؛ وبذلك فإن الفعل الإنجازي بيتمد قوته من معنى المطاوعة التي جاءت في فعلي الثرط وجو ابه، كما يستمد فعل المطاوعة (تَجَرَّدَ) قوته الإنجازية من دلالته على الماضي ليناسب

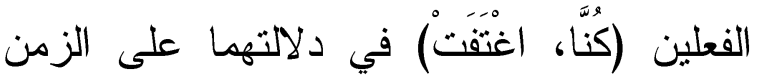

تجعل معناه للمطاوعة، يقول ابن السراج: "إذا أدخلت التاءَ على (فَعَّل) صسار للمطاو عة"(ri). وقد وردت صيغة (تَفََّّل) للمطاوعة في

قول طفيل الغنوي [من الطويل](؟َ):

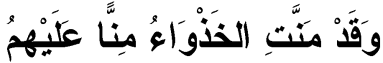

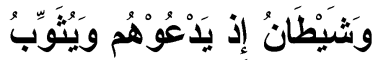

جَكَتُهُهُ كَنًْا بِبَطن تَبَالَةٍ

وخَيَّتَ من أسنْرَاهُمُ مَنْ تُخَبِّبُ

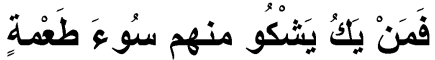

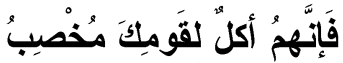

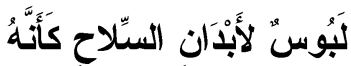

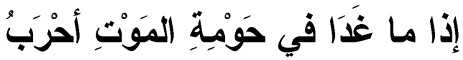

وكُنَّا إذَا ما اغَتْقَتِ الخَيْلُ غُفَّةً

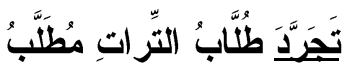

الخطاب الشعري هنا ضمن تصنيف

الإخباريات، و وقد تتوعت أزمنة الفعل بين الماضي و المضارع، وغلبت الجمل التقريرية الإخبارية على لغة الخطاب، وفي هذه الأبيات يوضح الشاعرُ أن استرخاءَ الخيلِ جعل أصحاب الثأر يهجمون لإدراكِ ثأرهم، وقد استعمل الشاعر صيغة الفعل (تَجَرَّدَ) لإبراز قصده في الخطاب في إطار من عناصر التداولية.

الأولى، إدارة إحياء التزاث القديم، إدارة الثقافة

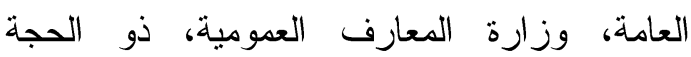

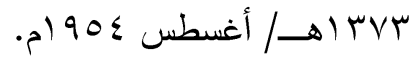

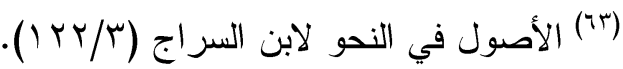

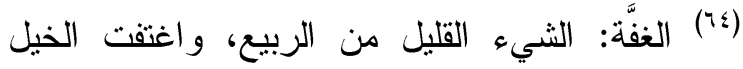
وتغفَّت: نالت غفة من الربيع ولم تكثر، التِّرات:

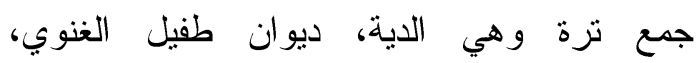


أعلى الجبل"(rי)، ويمكن إبراز قصد المتكلم مـنـ

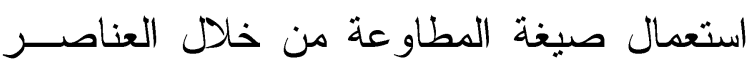

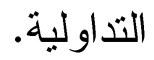
دور عناصر التداولية في بناء المغنح. أولًا: الإشاريات: يصف الثاعرُ الخيلَ بالسرعة ويشبهها بالصخرة التي تدلت (سقطت) من أعلى الانىاني الجبل، وقد استعمل الثاعر عددًا من الإثاريات للربط بين أجزاء التركيب في البيت الثعري،

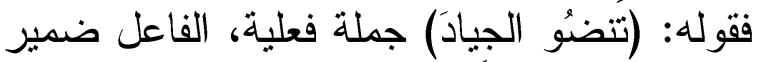
مستتر يعود على اسم سابق في اللفظ (سلهبة)، و هي إحالة ضميرية تحيل إلى سابق في الكلام. ثم جاء ضمير الهاء في قوله (كأنها) إثارة إلى (سلهبة)، وقد جاء الفعل الإخباري

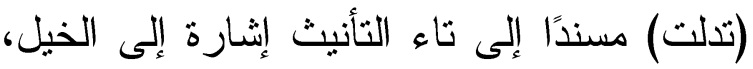

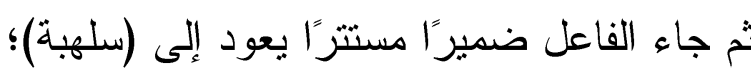

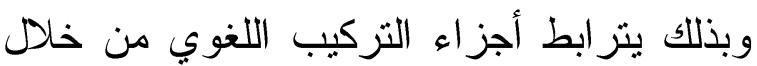
عنصر الإشاريات.

ثانيًا: الافتراض الإنشابق: الثاعر يتحدث عن الخيل ويصفها بالسر عة و القوة. ثالثًا: الاستلز ام الدواري: الثاعر في حديثه عن سرعة الخيل يشبهها بما يساويها في سرعتها، وهو سقوط الصخرة من أعلى الجبل، وقد عبر عن ذلك باستعمال فعل المطاوعة. رابعًا: الفعل الإنجازي: استعمل الثاعرُ الفعل

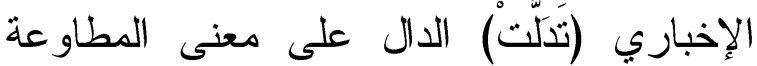
لبيان سرعة الخيل، تلك الخيل التي تستجيب

(T) انظر : شعر طفيل الغنوي دراسة فنية، محمد أحمد

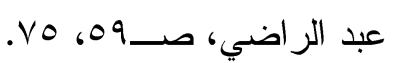

الماضي؛ فيصبح الفعل حينئذ على الحكاية، وتصبح القضية قضية حكاية. واختيار الثاعر للصيغة الصرفية يعد مدخلًا للولوج إلى معنى البيت؛ فاستعمال بنية

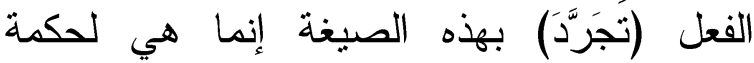
اقتضاها السياق التداولي في النص.

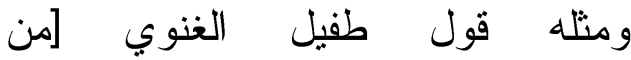

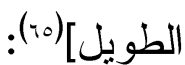

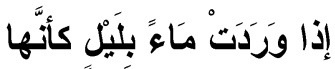

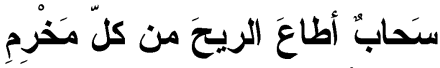

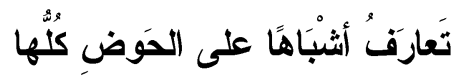

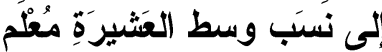

غَنمنا أباها ثم أحرَز نَسنها ضر ابُ العِدَى بالمَشَرَفَفي المُصَمِّم وكُلْ فتَى يَرْدي إلى الحَرْب مُطْنًَا

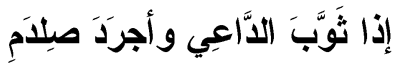

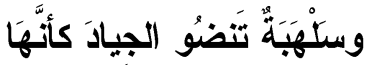

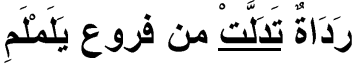
فنلتكَ أحياها وكلُ مُعَمَّمِ أريب بِنَنْعِ الضَّيَفِ غِير مُضَيَِّ

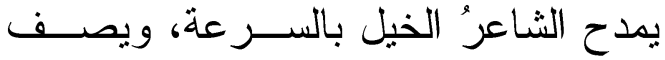

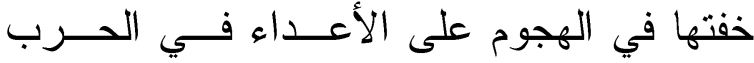
بالصخرة التي تسقط من أعلـى جبــل (يلملـــم)

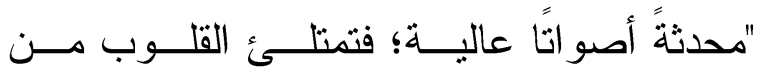

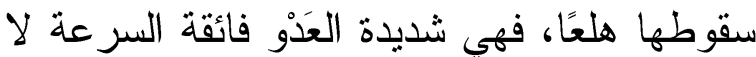

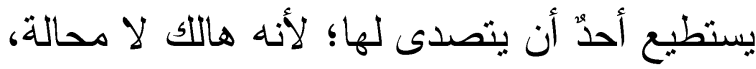
فشبه الفرس في سرعته بالصخرة الساقطة مسن (10) الستّلةبة: الطويلة، تتضو : تجاوزها، رداة: صخرة

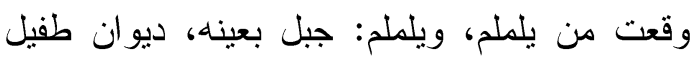

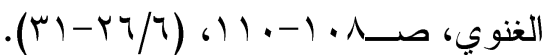


وقد وردت صيغة (تفعلل) للمطاو عة في

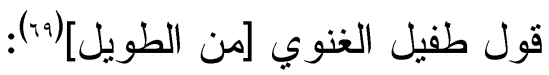

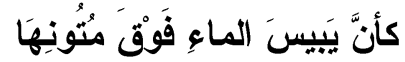

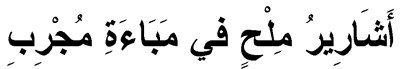

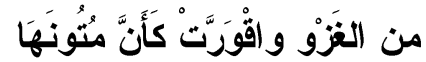
زَحَالِيفُ ولَدَانَ عَفَتْ بَعْدَ مَلْعبَ

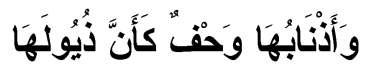

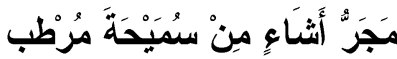

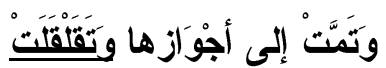

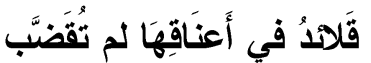

كأنَ سَّى قُطنْ النََّّ (ادِف خَفَقها

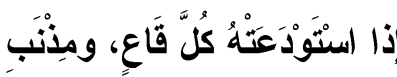

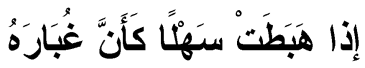
بجَاتِبه الأقصى دو اخن تَنْضُبْ يصف الثاعرُ حركةَ القلائد في أعنــاق

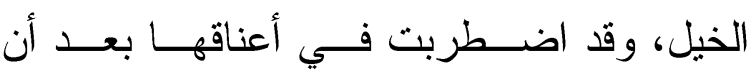
ضمرُت وهزلت، ولقد "كانت قلائدها حين بدأت

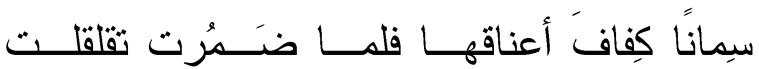

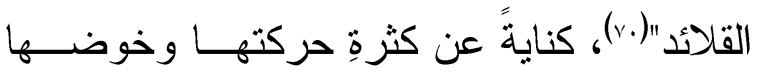
المعارك، فهي دائمة الحركة من كثرة المعارك. و الثاعر في خطابه عن الخيل يوضح دراته لنا كثرة حركتها؛ مما أدى إلى ضمور ها وقلقلة

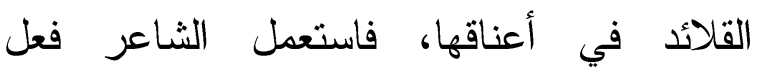
المطاوعة للالالة على هذا المعنى، ويمكن

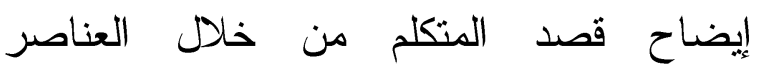

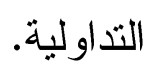

(19) الأجواز: الأوساط، تقلقلت: يُريد أنها كانت سِمانًا

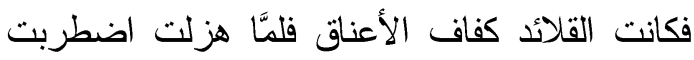

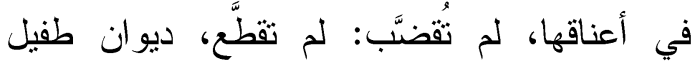

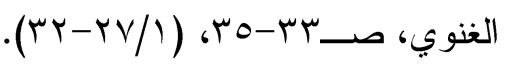

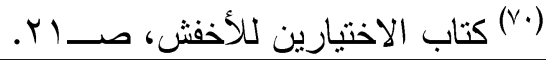

لفارسها حين يطلب الموقف سرعتها؛ فنتقاد مطيعة لأو امر الكر والفر في ميدان القتال. وقد افترض الطفيل الغنوي أن الخيل في سرعتها و ونطلاقها تساوي سرعة الصخرة الساقطة من أعلى الجبل، وفي هذا دليل على تطنى

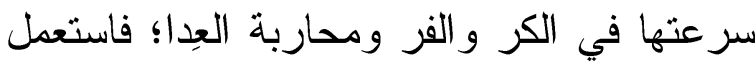
فعل المطاوعة للالالة على هذا المعنى، فكأن

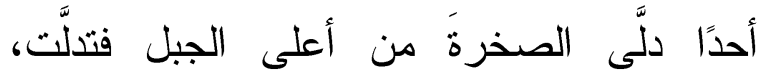
وكذلك فإن الفرس (الخيل) يستجيب لفارسه حينما يغمزه طالبًا منه السرعة في العدو

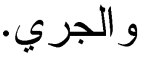

واختيار الثاعر للصيغة الصرفية الدالة على معنى المطاو عة لا يكون اختبارًا اعتباطيًّا، إنما يختار الصيغة التي تؤدي المعنى الذي لئي

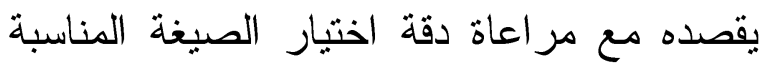
للمعنى لإبراز قصده في وصف انطلاق الخيل بسرعة سقوط الصخرة من أعلى الجبل؛ فمر اعاة حال (المخاطب/ المنلقي) تجعل عملية التواصل ناجحة وممكنة. ع) - صبغة (تَفْمَلَ).

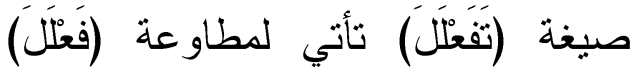

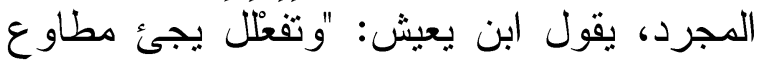

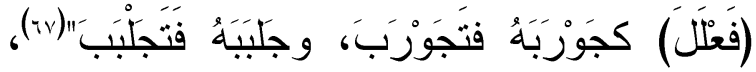

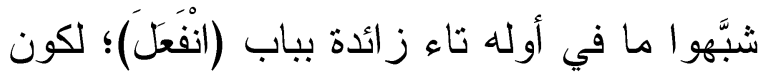
ذبي التاء مطاوعًا في الأغلب كما أن (انْفَلَ)

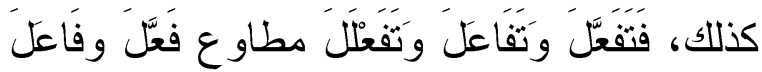
وَفَعْلَلَ) (1V)

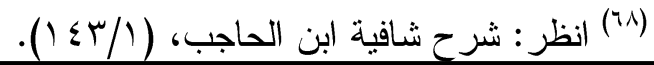




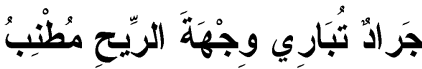

$$
\text { ومن بَطْنِ ذِي عَاجِ رِعَالْ كَأَنَّهَا }
$$

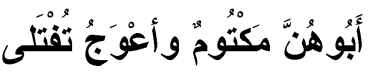

ورَادًَا وحُوًَا ليس فيهنْ مُغْربُ

إذا خَرَجَتْ يَوَمًْا أُعِيدَتَ كأَنَّها

عَوَاكِفْ طَيْر فِي السَّمَاعِ تَقَلَّبُ

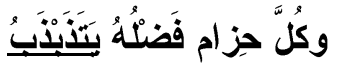

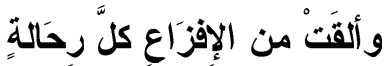

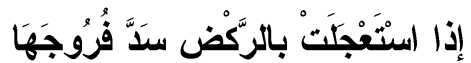

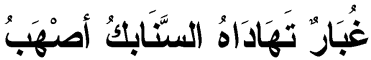

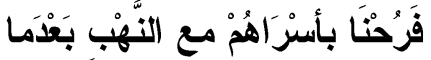

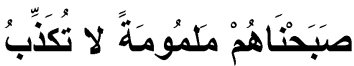

يصف الثـاعرٌ الخيل بالســرعة و النشـــاط،

وهي في كثرتها وتفرقها في المكان مثل الجراد

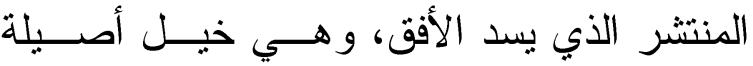

معروفة النسب، إذا غمز ها ر اكبها طالبَّـا منهـــا السرعة في العَدْوِ و الجري سد غبارُها الأفقَ من

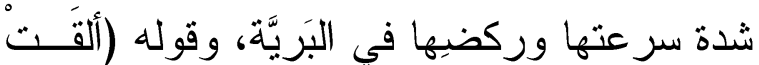

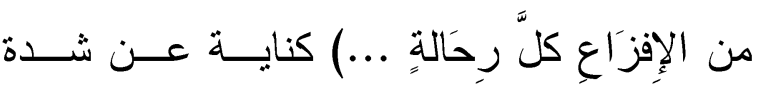
سر عتها وركضِها.

وقد استعمل الشاعر فعل المطاوعة

(يتذبذب) للالالة على حركة الخيل وقوتها في العَدْو، ويمكن إبراز قصد المتكلم من خلال

عناصر التداولية.

دور عناصر التداولبة في بناء المعنح.

أولًا: الإشاريات: قول الثاعر: (وألقت) الواو

عاطفة على ما قبلها، وتاء التأنيث إثارة إلى لفظ سابق في النص (رعال) أي: الخيل، و (كل

منه، يتذبذب: يتحرك، ديوان طفيل الغنوي،

$$
\text { صـ (YA-r }
$$

دور عناصر التداولية في بناء المعنح.

أولًا: الإشاريات: قول الشاعر (وَتََّتْ) الواو عاطفة تربط البيت الشعري بما قبله من أبيات القصبدة، وتاء التأنيث في آخر الفعلين (تََّنْ،

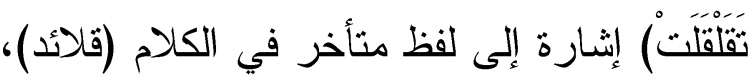
فهي إشارة إلى لاحق في اللفظ (إحالة بعدية)، و لاصقة التاء في أول المضارع (تُضََّّب) إثارة إلى (القلائد)، وضمير الهاء في قول الشاعر (أجو از ها/ أعناقها) إثارة إلى الخيل.

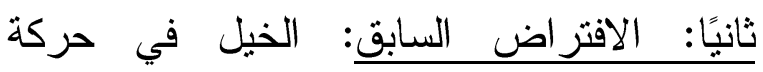
ونشاط؛ وبناءً عليه تتحرك القلائد في أعناقها وتتقلق؛ فحركة الخيل هي التي قلقلت القلائد في أعناقها. ثالثًا: الاستلز ام الحواري: جاءت قلقلة القلائد في أعناق الخيل كرد فعل لحركة الخيل. رِابعًا: الفعل الإنجازي: استعمل الثاعر الفعلين

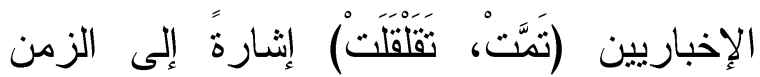
الماضي، كما استعمل الشاعر الفعل المضارع (تُضََّّب)، ولكن زمنه قد خلص للماضي لنفيه بــ ـ (لم)، ويستمد الفعل (تقلقلت) قوته الإنجازية من معنى المطاوعة التي تدل على أن ولن حركة الخيل مع ضمورِها هي السبب في قلقلة القلأئد، فلو كانت الخيل ساكنة ما تقلقلت القلائد ولا تحركت، وهو الهدف التداولي الذي يريد الشاعر إبرازه في البيت.

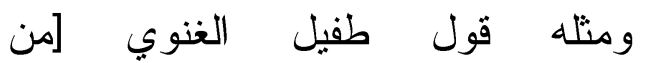

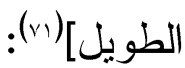

الرِّحالة: سرجّ من جلود ليس فيها خشب يُنَّنذ

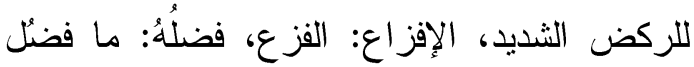


غَشَيْتُ بقُرَّا فَرَطَ حَول مكمَّل

مَغانِيَ دَار من سُعْادِ ومَنْزل

تَرَى جُلَّ ما أبقى السَّواري كأنَّهَ

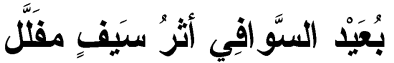

ديَارٌ لسُعدى إذ سُعَادُ جدَايَةُّ

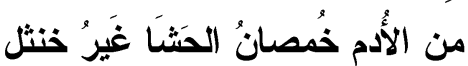

هِجانُ البَيَاضِ أُشْرِبَتْ لونَ صُفْرَةٍ

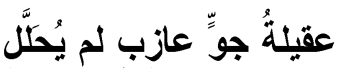

تَضِلْ المَدَارى في ضَفَائر ها العلى

إذا أُرسِلَتْ أو هكَا غَيَرْ مُرْنَ

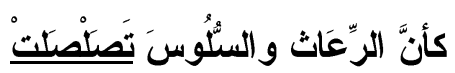

على خُشَشَاوَيْ جَأبَة القَرَنْ مُغْزل

يصف الثاعر" جمال محبوبته ودلالَهـا،

وقد تزينت بالحُلِي فكانت في أبهى صور الزينة،

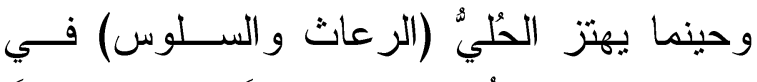
رقبتها أو أذنها تُحدِثِ صلصـــالًا، أي: صـــــاً ورنينا؛ فصوت الحُلي ورنينه جاء نتيجة اهنز ازٍ المر أةِ ودلالهِا في مشيتهِها، وقد شبه الثـاعر قوة

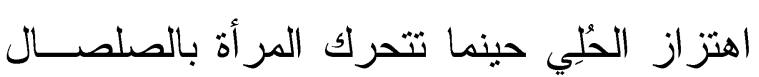
في قوة صوته المدوية في الآذان. دور عناصر التداولية في بناء المعنح.

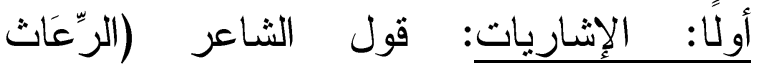

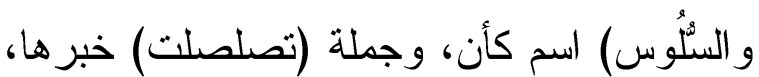
وقد تزابطت جملة الخبر مع اسم كأن بعلاقة

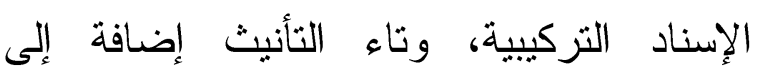
الضمير المستتر في الجملة الفعلية إثارة إلى إلى

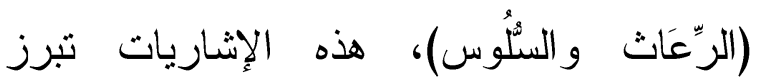

لؤلؤًاً واحدها سَلْس، الخُشَشَاء: العظم الذي يطول

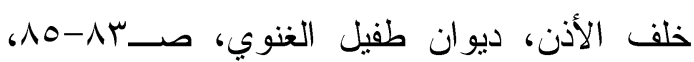
. $(7-1 / 0)$
رحالة) معمول الفعل، ثم عطف الثاعر (كل حزام) على (كل رحالة) بالواو العاطفة للربط بين المفردات، و الضمير المستنز في الجملة الفعلية (يتذبذب) يعود على (كل حزام) وجملة (فضله يتذبذب) في محل نصب حال لــ (كل ) حز ام) هذه الإشاريات تؤدي وظيفة الربط بين عناصر التراكيب النصية لإبراز دور التداولية في بناءٍ المعنى الذي يقصده الثاعر. ثانيًا: الافتر اض السابق: الخيل في حالة حركة و عَدْ، دل على ذللك قوله (يتذبذب)، أي: يتحرك.

ثالثًا: الاستلز ام الحواري: الحوار الشعري هنا يدور حول حركة الخيل وسرعتها في الركض، وإذا كانت الخيل في حركة، فمن الطبيعي أن الرحال عليها تتحرك و وتتذبذب، فالاستلزام الحواري هنا يفرض على الشاعر استعمال صيغة (يتذبذب) الدالة على معنى المطاو عة.

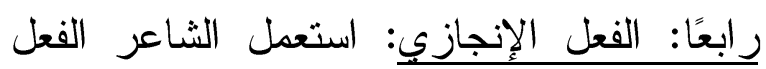
الإخباري (ألقت) دلالة على الحركة المصاحبة

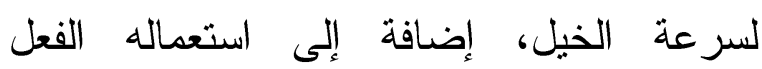
(يتذبذب) الدال على الحركة أيضًا، ويستمد الفعل قوته الإنجازية دن معنى المطاوعة دلالةً على الئ

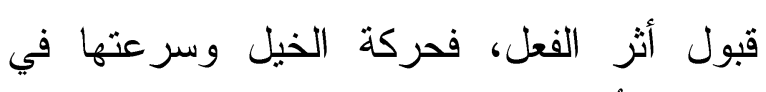
الركض تُذبذبِ فضل الحز ام فيتذبذب.

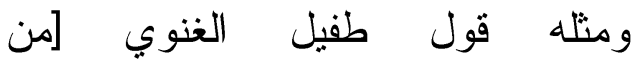

الطويل]

الجابة: العظيمة، المغزل: التي معها غز الها وهو

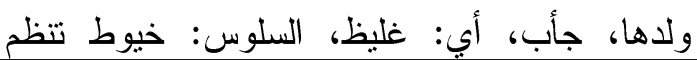


المبحث الثالث : تعلد المعنى في الصيفة الصرفية

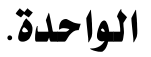

إن المبنى الصرفي الواحد متعدد الدلالة، حيث تستعمل الصيغة الصرفية الواحدة للتعبير عن أكثر من معنى، وتقوم القرائن السياقية في لإني النص بتحديد المعنى المقصود الذي يريده المتكلم، "و الدلالة الإفرادية للكلمة تكون صالحة للتشكل حسب الدلالة التي يقوم المتكلم أو المبدع بإنشائها، ولا تظهر تلك الدلالة إلا في التركيب؛ ولذا فإن الدلالة التركيبية للصيغة الصرفية معتمدة على الدلالة الإفرادية في بعض السياقات؛ فتعطي للصبغة معنى منفردًا بعيدًا عن السباق،

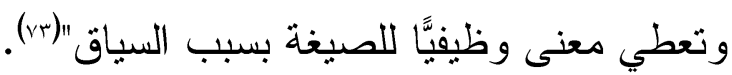
وظاهرة تعدد المعنى في الصيغة الصرفية الواحدة تحكمها القرائن السياقية؛ ومن لعن لهن ثََّّ تظهر قيمة السياق في بيان معنى الصيغة الصرفية ووظيفتها في النص، ومعظم الصيخ الصرفية تؤدي معان وظيفية متعددة بحسب ووطني سباق الاستعمال، وتعدد المعنى الوظيفي في ونئه الصيغة الصرفية "يعطي اللغة العربية مرونة وقدرة على التعبير عن مختلف الأغراض؛ إذ إذباء

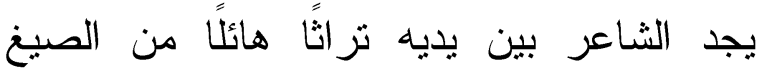

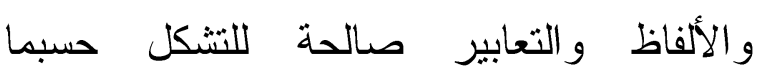

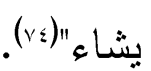

(انظر : المعاني الوظيفية لصيغة الكلمة في التركيب، (VT)

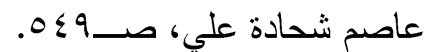
(V乞) صلاح، صـالا1، دار غريب للطباعة والنشر و التوزيع، القاهرة، ع .. بَم.
الترابط بين عناصر التزكيب اللغوي وتسهم في لئ إيضناح المعنى. ثانيًا: الافتر اض السابق: الشاعر يتحدث عن حُلِي المر أة وزينتِها و اهتز از حليّها أثناءَ حركتِها. ثالثًا: الاستلزام الحواري: فرض الاستلزامُ الحواري على الثاعر استعمال صيغة الفعل (تصلصلت) كنتيجة لحركةِ المر أة ودلالها في خطوَ اتِها.

رابعًا: الفعل الإنجازي: استعمل الثاعر الفعل

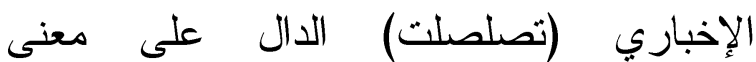
المطاوعة وقبوله أثز الفعل؛ فحركة المرأة في

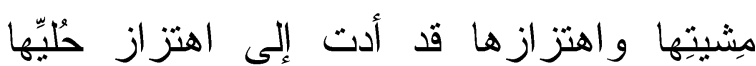
و إحداثه صوتًا ورنينًا، وقد اختار الثاعرُ فعلًا إنجازيًّا (تصلصلت)؛ ليتتاسب مع حركة الحُلي الذي يُحدِث رنينًا قويَّا حين اهتز ازه، وقد اعتمد الثاعر التشبيه لهدفٍ تداولي، وهو بيان ما تتمتع به هذه المر أة من الزينة.

نخلص مما سبق: أن التداولية تسهر

بدور بارز في إيضاح معنى المطاوعة، وكل فعل من أفعال المطاوعة يحمل قوة إنجازية في سياق الاستعمال التداولي، ويفترض أن هذه الأفعال يسبقها فعل من مادتها تستجيب لأثره في إطار من عناصر التداولية التي تتضافر في إيضاح المعنى، وإيراز قهدية الشاعر في في استعماله الصيغ الصرفية. وبذلك يتضح لنا تعدد الصيغ الصرفية الدالة على معنى المطاو عة، استعمل منها الثاعر ما ناسب قصده مع مراعاة مبدأ الإفادة عند المتلقي. 


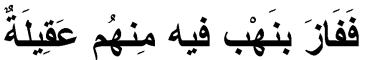

لها بَشَرَ صَافِ ورَخَصُ مُخَضَّبُ

فلا تَذَهَبُ الأحسَابُ من عُقْر دَارنا

ولكنَّ أثثباحًا من المـال تَذَهَبُ

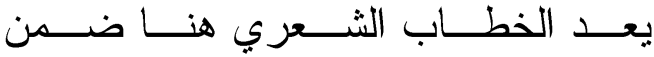

الإخباريات حسب تصنيف سيرل، وقد تنوعــت الأفعال بين الفعل الماضي الدال على الثقريــر ، و الفعل المضارع الدال على التجدد والاستمرار،

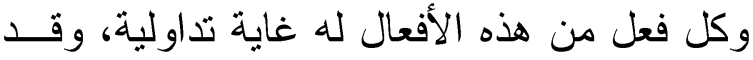
خلت الأبيات من فعل الأمر، وهو ما يتتاسب مع هـ السرد القصصي، وغلبــت الجمــلـ الإخباريـــة التقريرية على الخطاب، و الهدف التداولي مــن هذه الأبيات هو وصف الشاعر قوة السهم وقـت

$$
\text { انطلاقه و إصابته لهدفه. }
$$

فالشاعر يصف السهر الذي لُّعدَّ للقتال

و الثأر، وهو يبرق في يد فارسه، ويتحين

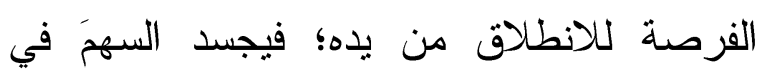
صورة إنسان ير اقب كافة الاتجاهات في المعركة للانطلاق نحو هدفه، ولم ينسَ الشاعر أن يصف الحالة النفسية حيث تبدو عليه ملامح الغضب حتى بُنثأر له.

وقد استعمل الثاعر صيغة (رقيب) فعيل) بمعنى اسم الفاعل، أي: بدلالة التجدد و الحدوث وذللك لوظيفة تداولية، وهي التعبير عن تأهب السهر لمراقبة الموقف في المعركة، ورغبة الشاعر في إيصال هذا المعنى إلى المتلقي، ويتضح ذلك من خلا لـ العناصر التذاولبة التي تعين على إظهار المعنى.
وستقتصر هذه الدر اسة على تعدد المعنى في صيغة (فعيل)؛ وذللك لأنها تتضمن أكثر من معنى وظيفي، فهذه الصيغة ذات قوة دلالية بين الصيغ الصرفية، لا تقتصر دلالتها على المبالغة فقط، بل تتعداها إلى دلالات أخرى: (اسم الفاعل، المبالغة، الصفة المشبهة، المصدر، اسم المفعول، ... إلخ) بحسب سياق الاستعمال، فتتعدد وظائفها التداولية في النص الشعري، ويتحدد المعنى المرتبط بها من خلال السياق بناءً على الأغراض التداولية التي يريد الشاعر

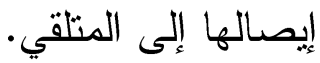
ومن المعاني الوظيفية لصيغة (فعيل) في

\section{شعر طفيل الغنوب ما يلي:} 1) - فعيل بمعنى اسم الفاعل. تأتي صبغة (فعيل) بمعنى اسم الفاعل؛ وذلك لأغراض تواصلية تداولية بين المتكلم و المخاطَب؛ ومن ذلك قول طفيل الغنوي في نهاية قصيدته الثانية [من الطويل] (vo):

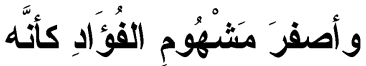

غَدَاةَ النَََّى بالَزَّعْفَرَانَ مُطَيَُّ تَقِلْتُ عليها تَفَلْةَة ورمَسَحْتُهُ بثَوبِيَ حَتَّى جلدُه مُتَقَوبُِّ

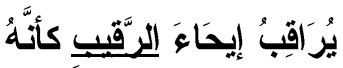

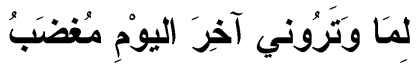

ير اقب إيحاء الرقيب، أي: من سرعة خروجه

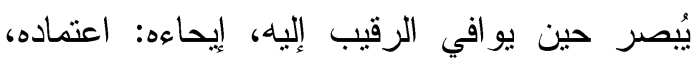

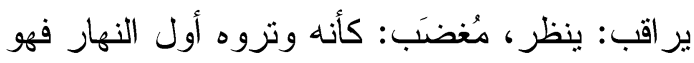

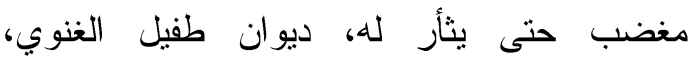


الفاعل إنما كان لغرض تداولي، فصفة المراقبة غير ثابتة في السهم، ولكنها نازمه في المعارك و القتال فقط حتى يثأر لنفسه ولقبيلته.

\section{r) - فعيل بمعنى الصفة المشبية.}

تصاغ الصفة المشبهة من الفعل اللازم

للالالة على اتصاف الذات بالحدث على وجه الثبوت و الدو ام، وقد وردت صيغة (فعيل) بمعنى الصفة المشبهة لأغراض تواصلية تداولية في

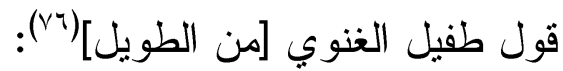

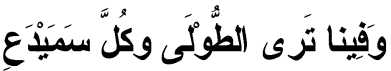

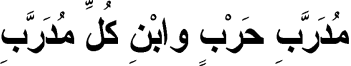

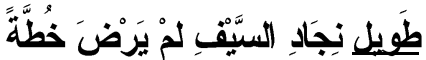

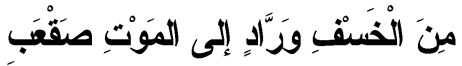

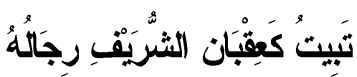

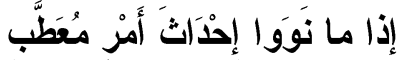

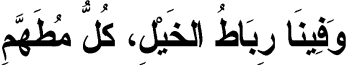

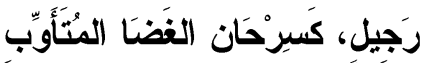

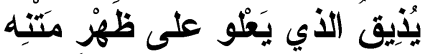

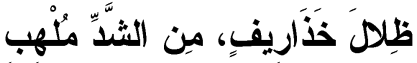

يعد الخطاب الثعري هنا ضمن تصنيف

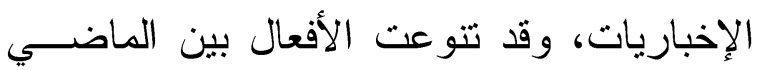
و المضارع، وغلبت الجمل الثقريرية الإخباريــة

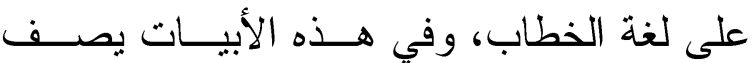
الثاعر قومه بالثجاعة والإقدام في الحــروب،

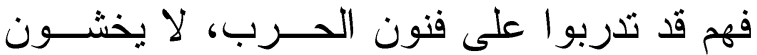

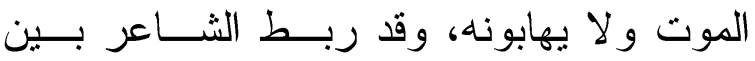
شجاعة الفرسان وطول القامة.

(vi) الخَسْف: الضَّْمُ، الصقعب: الطويل، الورَّاد: من

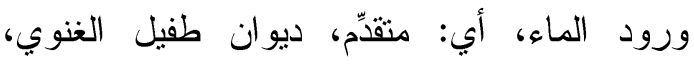

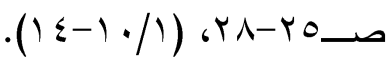

دور عناصر التداولية في بناء المغنح.

أولًا: الإشاريات: استهل الثاعرُ البيت الثالث بالفعل المضارع (براقب) دلالة على تجدد المراقبة واستمرارها خلال فترة المعركة، وقد امتد فعل المر اقبة باستعمال صيغة (رقيب)، فهي صفة تتجدد بتجدد القتال، وتتنهي بانتهاء الحرب وزو الها، و الفاعل المستتر في الجملة الفعلية يعود إلى (أصفر مشهوم) في البيت قبل السابق، وهو

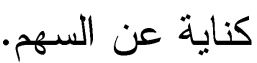
ثانيًا: الافتر اض السابق: الثاعر يُجسِّم السهح في

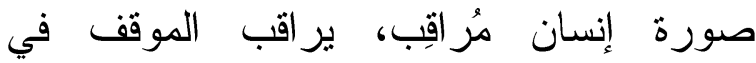
المعركة حتى يثأر لنفسه.

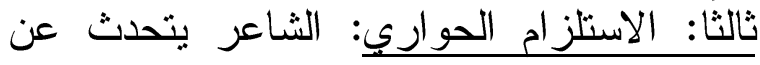

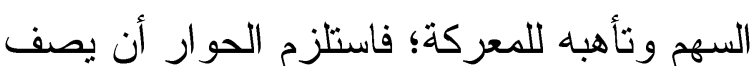
الشاعر هذا السهم، ويحدد وظيفته في المعركة بمر اقبة الموقف.

رِابعًا: الفعل الإنجازي: استعمل الثاعر فعل المر اقبة وصفا لحالة السهم في المعركة، ويستمد العدان الحدث الكلامي قوته الإنجازية من استعمال

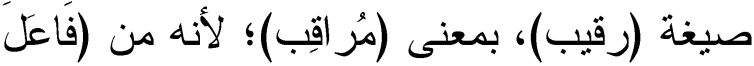

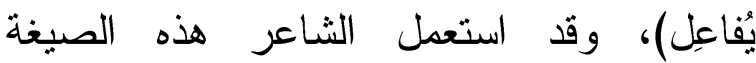
الصرفية لإبراز رغبته في الثأر و الانتقام، وإرادته معنى الحدوث و التجدد كلما خاض الفرسان معركة أو قتالا، فصيغة (فعيل) أبلغ تعبيرًا في قصد المنكلم. و التداولية تدرس اللغة بأبنيتها الصرفية وتر اكيبها النحوية بوصفها نظام تواصل بين طرفي الخطاب، و التحليل التداولي يوضح أن استعمال الثاعر صيغة (فعيل) بمعنى اسم ولئ لئل 


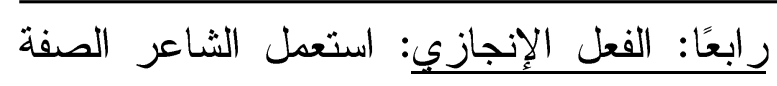
المشبهة (طويل) كناية عن طول فرسان القبيلة

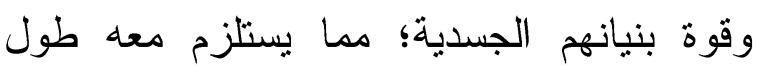
نجاد السيف، فصيغة (فعيل) "تحمل دلالة الثبات

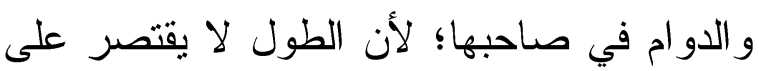

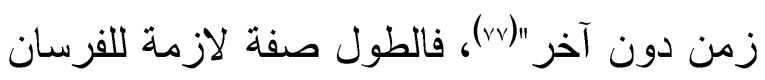
وهي صيغة مدح لهم دلالةً على قوتهم البنيانية و الجسمانية، فالثاعر يكني عن طول الفارس دلى لهن

$$
\text { بطول نجاد سيفه. }
$$

ولولا فهم المنلقي لمعنى الصيغة لهنه

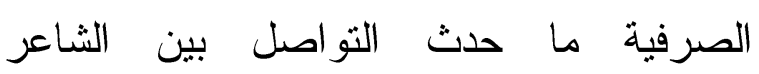

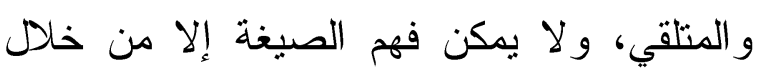

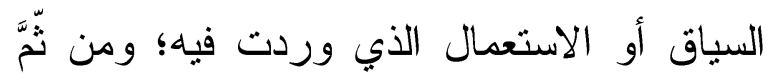
فإن التواصل ينوقف على فهم المتلقي لقصد الثاعر من أبنية النص وتر اكيبه. وقد وردت صيغة (فعيل) بمعنى الصفة التهن المشبهة من مضعف الثلاثي اللازم) (v^) في قولى طفيل الغنوي [من الطويل](Va):

الزيادة ومعانيها في الأبنية الصرفية، د/ خالد عبد

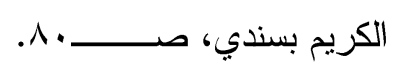

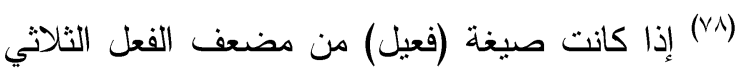
اللازم فالراجح أنها صفة مشبهة؛ وذلك لقلة ورود

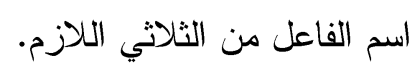

(v9) الأنباء: الأخبار، حملها خفيف: بعني: الأخبار،

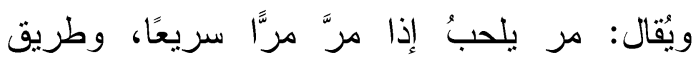

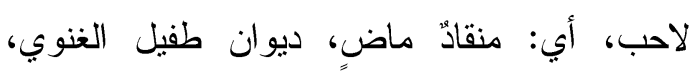

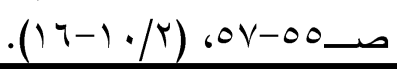

وقوله: (طويل/ فعِيل) صفة مشبهة من

الطول؛ لأنها من الفعل الثظلاثي اللازم (طَوْلَ)

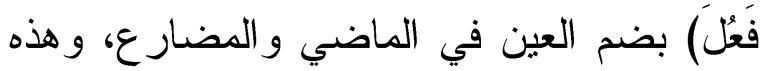
الصيغة لا تكون إلا لازمة، و الصفة المشبهة لا للاعل

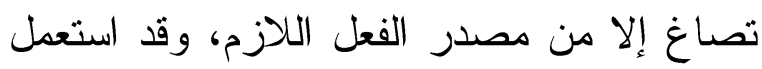

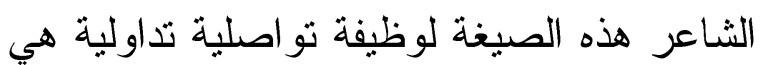

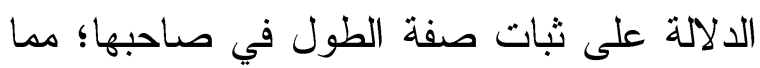
يستّعي معها طول نجاد السيف لتتاسب طول

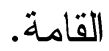
دور عناصر التداولية في بناء المغنى.

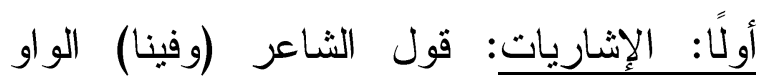
عاطفة تربط بين الأبيات في القصيدة، وضمير الجمع (نا) يعود على قبيلة الثاعر وقومه، وهو شيء خارج النص (إحالة خارجية)، ثم يخاطب الشاعر المتلقي قائلًا: (ترى) فالفاعل ضمير مستتر يعود إلى شيء خارج النص أيضًا (إحالة

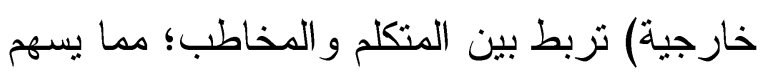
في تحقيق التواصل بين الثاعر و المتلقي، أما الضمير المستتر في جملة (لْمُ يَرْضَ خُطَّةً فعائد إلى الفارس الذي كنَّى عنه الثاعر بالصفة الثنة المشبهة في أول البيت.

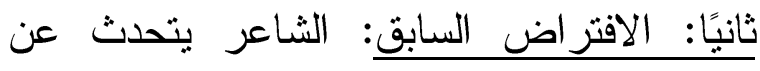
فرسان قومه ويصف شجاعتهم.

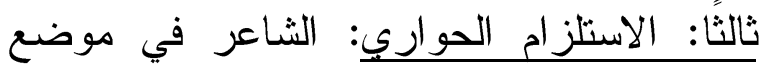
المفاخرة بقومه؛ لذلك استلزم الحوار استعمال ضمير الجمع، ووصف فارس القبيلة بالقوة وطول القامة؛ وذلك باستعمال صيغة الصفة

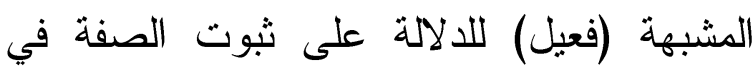


الصفة الشبهة إنما جاء لغاية تداولية تو اصلية، وهي الدلالة على اتصاف الذات بالحدث على الثل وجه الثبوت والدوام يتضح ذلك من خلال عناصر التداولية.

دور عناصر التداولية في بناء المغنى. أولًا: الإثاريات: استهل الثاعر البيت قبل

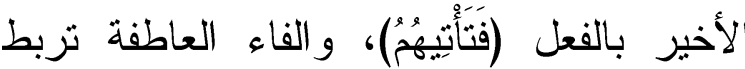
البيت الشعري بما قبله في القصيدة، والعنصر الإثاري (هم) إثارة إلى سابق في الكلام، وهذه

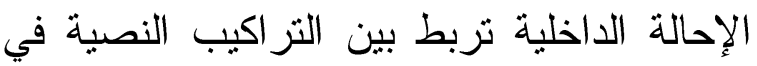
القصيدة، وضمير الجمع في شبه الجملة (عنا) إثارة إلى شيء خارج النص (إحالة خارجية)، و الضمير في قوله (حملها) إثارة إلى الأنباء،

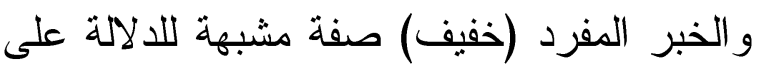
الثبات، والجملة الاسمية (حملها خفيف) في محل نصب حال لـ (الأنباء) ورابط جملة الحال بصاحبها هو ضمير الهاء وواو الحال. ثانيًا: الافتراض السابق: الثاعر يفتخر بقومه وبشجاعتهم في الحرب.

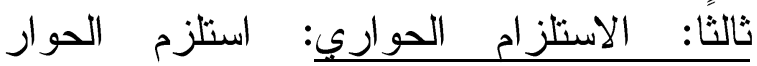
استعمال الثاعر صيغة (خفيف) للالالة على الانلى ثبات الصفة في موصوفها.

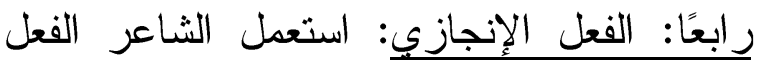

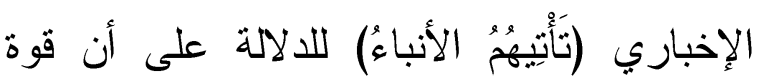
قومه وشجاعتهم قد ذاع صيتها بين القبائل، ويستمد الحدث الإنجازي قوتَهُ من استعمال صيخة (خفيف) بمعنى الصفة المشبهة دلالةً على الألى شهرة قومه بالقوة و الشجاعة بين القبائل.

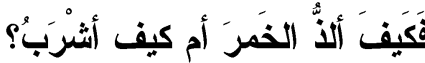

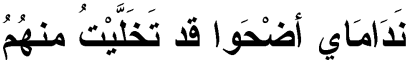

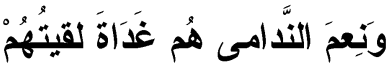

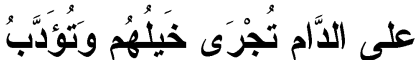

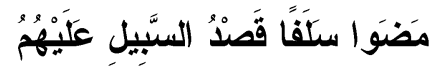
وَصَرَفُْ المَنَاِيَا بالرِّجَال تَقَلَّبُ ألا هَل أتى أَهْلَ الحِجَاز مُغَارُنَا

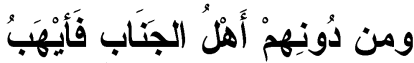

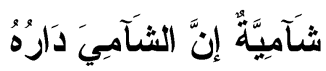

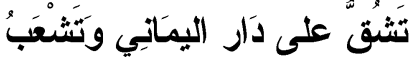

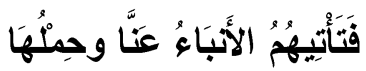

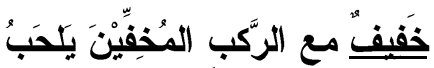

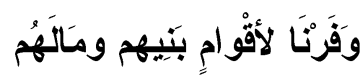

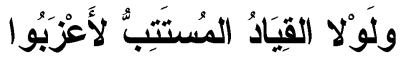

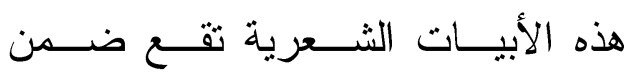
الإخباريات حسب تصنيف سيرل، وقد تتوعـــ

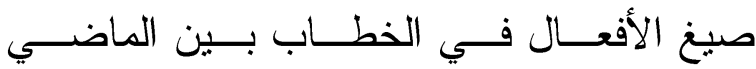

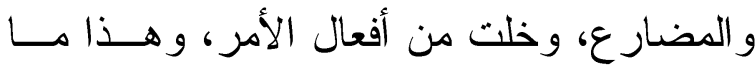

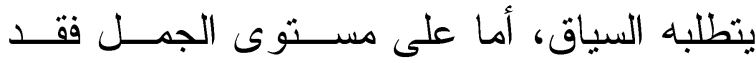
تتوعت بين الجمل الخبرية و الجمــل الإنثـــائية الاستفهامية، وفي الاستفهام طلب المعرفة، وهذا

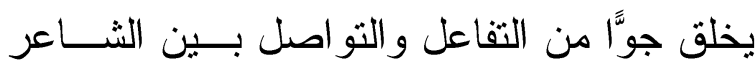
ومتلقيه، وتنوع الجمل في الخطاب الثشعري لــــ

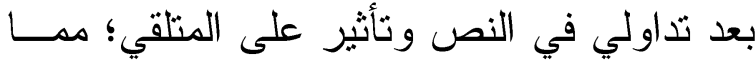
يسهم في التو اصل بين الثاعر و المتلقي. ونلاحظ استعمال الثاعر حرفًا من لناعل

حروف المعاني (ألا) لغرض تداولي، وهو إفادة المتلقي التتبيه لما يُقال لاحقًا.

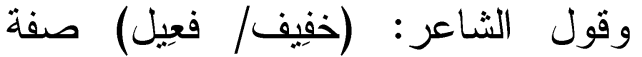
مشبهة؛ لأنها من الفعل الثلاثي المضعف اللازم

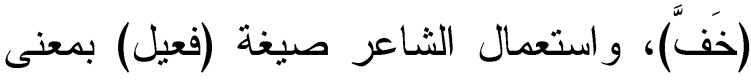


تقع هذه الأبيات الشعرية ضمن تصــنف لـاف

الإخباريات، وقد غلب استعمال الثاعر للأفعال

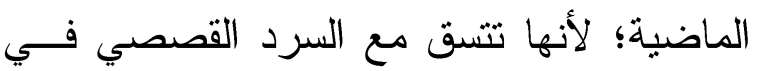

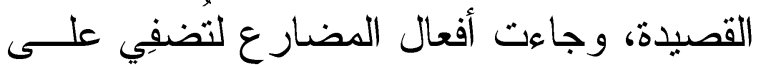

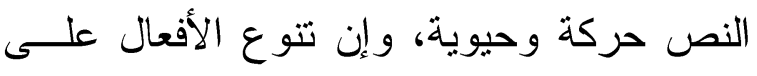
هذا النحو في الخطاب الثعري يحقق التو اصــل بين الثاعر و المتلقي.

وفي هذه الأبيات يبين الثاعر أن فرسان قبيلته قتلوا من الأعداء مقتلة عظيمة؛ ولذلك هده استعمل جمع الكثرة (قتلى جمع قتتيل) بمعنى مقتول؛ وذلك لوظيفة تداولية، وهي التعبير عن كثرة القتل في العدو، ثم استعمل الثاعر لفظة (أسير) بمعنى مأسور، ووصفها باسم الدفعول

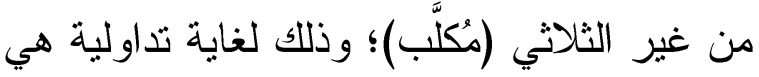
الدلالة على إحكام الأسر في العدو، فالمعنى الوظيفي يتحدد من خلال السياق بما يحمله من قر ائن تدل على معنى الصيغة الصرفية. و الصيغة الصرفية إذا استعمِلت في سياق لقئه

محدد فإنها تؤدي وظائف دلالية محددة، وقد يتغير معنى الصيغة الصرفية بتغير السياق أو المقام؛ لأن "المعانى الوظيفية التى تعبر عنها المباني الصرفية هي بطبيعتها تتسم بالتعدد والاحتمال، و المبني الصرفي الواحد صالح لأن يعبر عن أكثر من معنى ما دام غير متحقق

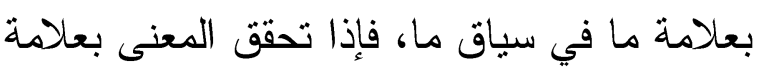

ثم تزداد قوة الحدث الإنجازي باستعمال

الثاعر صيغة اسم الفاعل من غير الثلاثي (المخفين) من نفس المادة المعجمية (خفق)، و لاشك أن تحديد معنى الصيغة الصرفية يوجه المخاطب إلى فهم مر اد المتكلم. و الغرض التذاولي من استعمال الثاعر الصفة المشبهة (خفيف) هو الدلالة على ثبوت

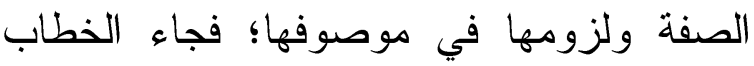

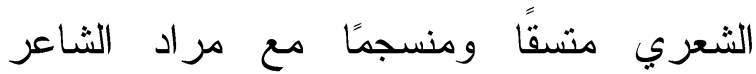
وقصده.

r) - فعيل بمعنى اسم المفعول.

تأتي صيغة (فعيل) بمعنى اسم المفعول

للالالة على الاستمرار وثبات الصفة؛ فصيغة (فعيل) أكثر ثباتًا من صيغة مفعول؛ لأنها تدل على أن الوصف قد أصبح كالسجية في صاحبه. وقد وردت صيغة (فعيل) بمعنى اسم

المفعول لوظائف تو اصلية تداولية في قول طفيل الغنوي [من الطويل](.)؛

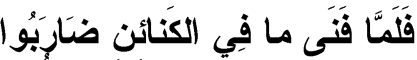

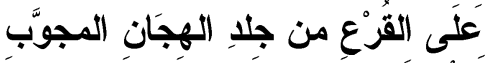

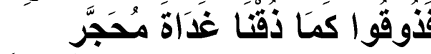

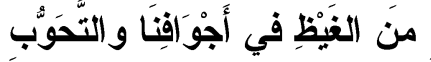

وما لا يُعَدُ من أَسبير مُكَلَّب

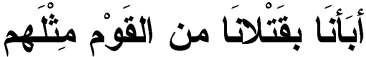

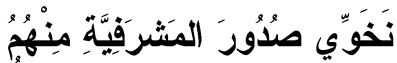

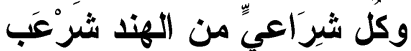

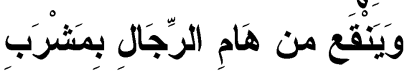
بضرَبْ يُزيلُ الهَامَ عن سكَنَاتِها

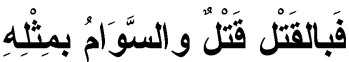

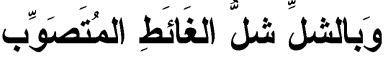

أبأنا بقتلانا:، أي: حملنا بواء بهم، و البواء: أن يقتل

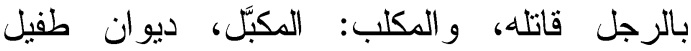

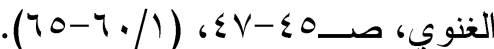


ففرض الاستلزام الحواري على الثاعر استعمال لفظتي (قتلى، أسير) في هذا الدقام التخاطبي لغاية تداولية، وهي الدلالة على كثرة القتل وإحكام الأسر في العدو، فالمقام مقام فخر

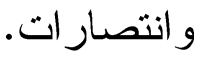

رابعًا: الفعل الإنجازي: استعمل الثاعر الفعل

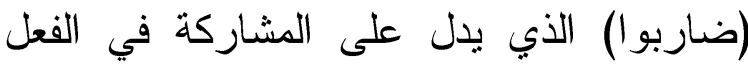
وذلك لغاية تداولية، وهي الدلالة على تبادل الضرب بالسيوف بعد انتهاء التزاشق بالسهام؛ مما يدل على قوة المعركة، وشجاعة قبيلة (غني)

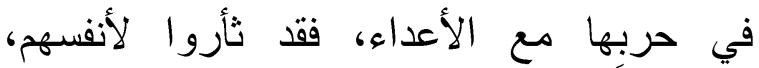
و عادو ا بالأسرى مكبكّلين في القيود و الحديد. ويستمد الفعل الكلامي قوته الإنجازية من استعمال الشاعر لفظة (تتلى)، وهي جمع قتتيل بمعنى مقتول للالالة على إصابة ثأرهم بكثرة القتل في العدو، كما يستمد الحدث الكلامي قوته الإنجازية من استعماله لفظة (أسير) بمعنى مأسور، ووصفها بصيغة اسم المفعول (مُكبَّل)

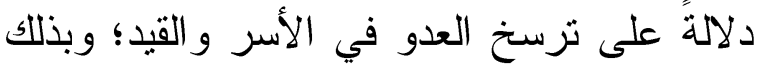
فقد حققت الصيغة الصرفية الهدف التداولي من استعمالها في سياق الخطاب الشعري. ولكل لفظة دلالة خاصة، فحينما تستعمل لفظة دون أخرى فإنها تحمل دلالة دون غيرها، فهي قادرة على إيصال المقاصد التي يريدها المتكلم إلى مستمعيه، فالاختيار لا يكون بطريقة

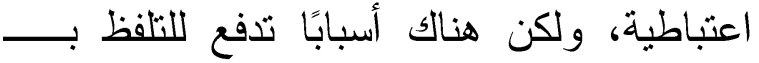

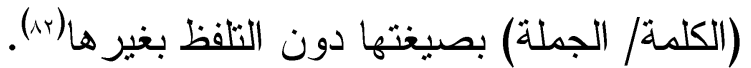
(Ar)

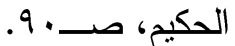

أصبح نصنَّا في معنى واحدٍ بعينه تحدده القر ائن اللفظية و المعنوية و الحالية على السو اء" (1). فقول الثاعر (أسير) المعنى المقصود (مأسور)؛ وإنما جاء الاستعمال بصيغة (فعيل) لأسرار بلاغية تداولية تتمثل في إفادة صيغة (فعيل) لمعنى لا يتحقق في صيغة مفعول، وهي الدلالة على الثبات مع إفادة معنى المبالغة في الصفة. دور عناصر التذاولية في بناء المعنى.

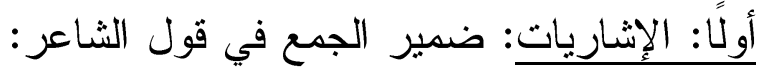

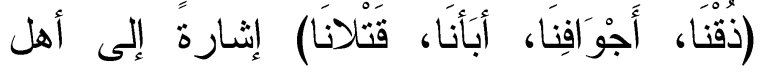
الثاعر وقبيلته، وهي إحالة خارجية تحيل إلى الى الى الثالي شيء خارج النص، كما أن واو الجماعة في قوله

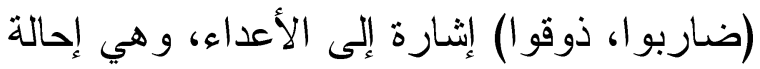

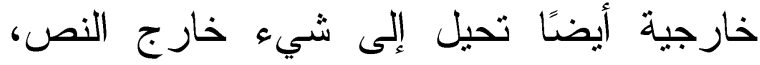
و هذه الإثاريات تربط النص بالسياق المحيط به.

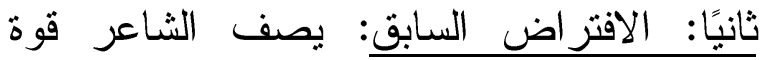

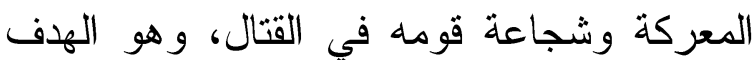
التداولي الذي يسعى الثاعر إلى إبرازه من وهي خلال استعماله صيغة (فعيل) بمعنى مفعول.

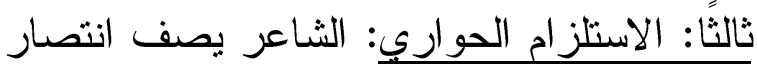
قومه على العدو؛ ولذلك استلزم الحوار التعبير عن غرض الثاعر بألفاظٍ وصيخ تدل على قوة

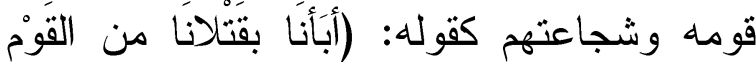

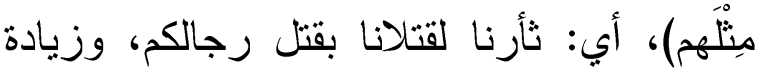
على ذلك كثرة الأسرى المكبَّلين في الحديد، (ال) اللغة العربية معناها ومبناها، د/ تمام حسان، صـبرجا، وانظر: الجملة الوصفية في النحو

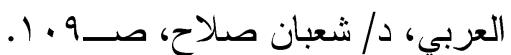


قضية المعنى من خلال اهتمامهم بمعاني

$$
\text { الصيغ الصرفية. }
$$

) تعتمد التداولية في المقام الأول على البعد

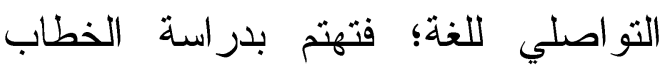

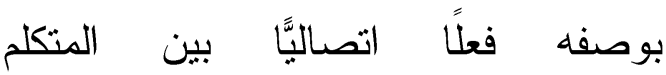
و المخاطَب.

0) تهتم التداولية بدراسة اللغة في سياق الاستعمالات المختلفة؛ لأن الهذف منها لألها تحويل (الخطاب/ المنطوق) إلى أفعال

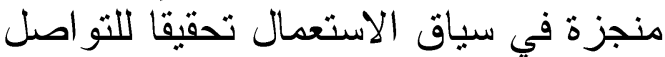
بين عنصري الخطاب. (1) تقوم التداولية بدراسة الصيغ الصرفية في لي الاستعمال؛ لتبحث في مدى نجاح العملية التواصلية بين المبدع و المتلقي، فتهنم بكل

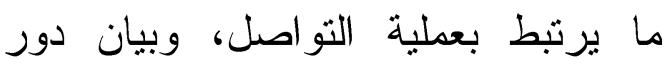
المتكلم في صياغة الخطاب، ودور المخاطب في فهمه، وكل الظروف المحيطة بإنجاز الرسالة اللغوية، فهي در اسة الاستعمال اللغوي. V طاهرة العدول فيها تجاوز الدلالة الأصلية للصيغة الصرفية إلى دلالات أخرى،

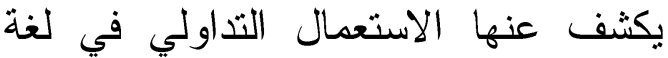
الخطاب للتواصل بين المتكلم و المخاطَب، وتحقيق أهداف تداولية تخاطبية في سياق لأن

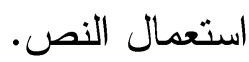

^) العدول في الصيخ الصرفية يكثف عن دلالات التو اصل بين طرفي الخطاب، وهذا ما نلمسه في عدول المتكلم عن صيغة إلى

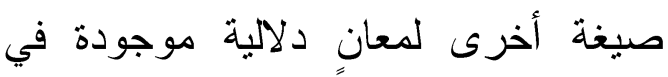

و هكذا تؤدي الصيغة الصرفية (فعيل)

وظيفة تداولية نو اصلية بين الثاعر و المتلقي في سياق الخطاب الثعري من خلال تأكيد الصفة وثباتها للوصول إلى المعنى الذي بقصده الثاعر في إطارٍ من عناصر التداولية. وبذلك يتبين لنا أن للصيغة الصرفية الواحدة القدرة التداولية في التعبير عن أكثر من معنى بحسب قصد المتكلم ومراده، فالصيغة الصرفية الواحدة تعطي أكثر من معنى بحسب السياق أو الاستعمال التداولي. الخحاتقة والنتائج.

من خلال الدقاربة التداولية لارتباط الصيغة الصرفية بالمعنى في شعر طفيل الغنوي

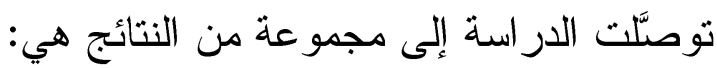
(1) الصيغة عنصر من عناصر بناء المعنى؛ فهي تخص البناء الصرفي بدلالة محددة، وتسهم في تشكيل معنى الكلمة، وأي تغيير في مبنى الصيغة يؤدي إلى تغيير في دلالة الكلمة.

r) الاقة في اختيار الصيغة الصرفية لها أثرها البالغ في أداء المعنى، ومبنى الصيغة الصرفية ومعناها ذو أثر شكلي ودلالي في الئي الئي مبنى التركيب اللغوي؛ لأنها تمثل أفعالًا

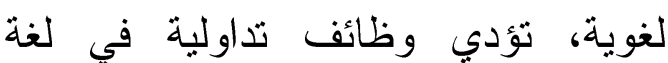

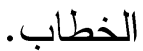
r) قضية المعنى تشكل النظرية الصرفية عند العرب، فهي الغاية الأولى من التحليل

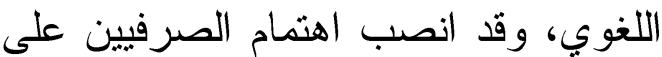




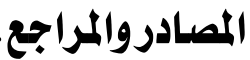

\section{أونًا : المراجع والكتب العربية.}

( ) آفاق جديدة في البحث اللغوي المعاصر،

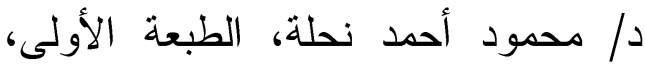

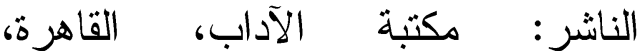

$$
\text { r }
$$

ץ) الاتجاه التداولي و الوظيفي في الدرس اللغوي، د/ نادية رمضان النجار، الطبعة

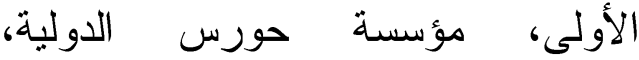

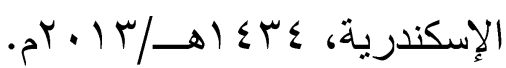

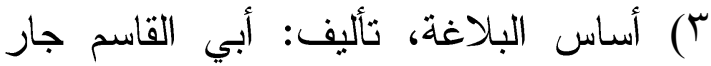
اله محمود بن عمر بن أحمد الزمخشري

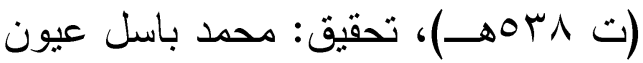
السود، الطبعة الأولى، منشور ات: محمد التهات

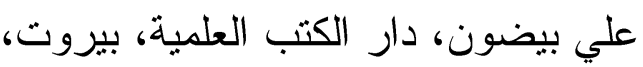

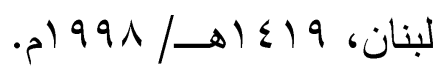

؛) الأسلوبية والأسلوب، عبد السلام المسدي،

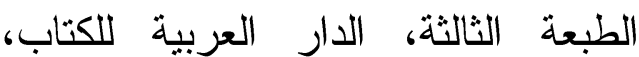

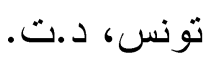

0) الإشهار القراني والمعنى المعرفي في ضوء النظرية العرفانية والمزية المفهومي و التذاولية، د/ عطية سليمان أحمد، الأكاديمية الحديثة للكتاب الجامعي، القاهرة، ع الثبام. 7) الأصول في النحو، تأليف: أبي بكر محد بن سهل بن السراج النحوي البغدادي (تآآهـ)، تحقيق: د/ عبد الحسين الفتلي، الطبعة الثالثة، مؤسسة الرسالة،

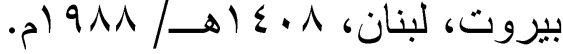

الصيغة المعدول إليها دون الصيغة المعدول عنها تخدم المعنى المطروح من الهن قبل المنكلم في إطار من العناصر التداولية التي تعين على إيصال غرض المتكلم إلى فلى المخاطب. 9) اللغة العربية تتميز بظاهرة تعدد الصيغ

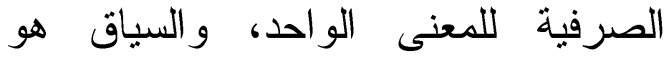
الفيصل في تحديد دلالة الصيغة، والكثف

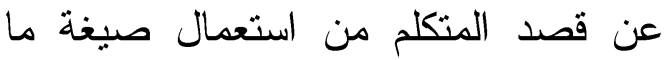
دون غيرها من الصيغ الصرفية في سياق

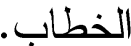
• (1) التداولية تسهم بدور بارزٍ في إيضاح معنى المطاوعة، وكل فعل من أفحال المطاوعة يحمل قوة إنجازية في سياق الاستعمال التداولي، ويفترض أن هذه الأفعال يسبقها فعل من مادتها تستجيب لأثره في إطار من عناصر التداولية التي تتضافر في إيضاح

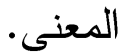
(1)للصيغة الصرفية الواحدة القدرة التداولية في التعبير عن أكثر من معنى بحسب قصد الكد

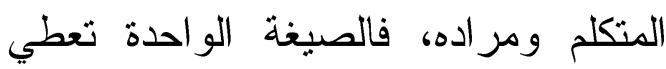
أكثر من معنى بحسب السياق أو الاستعمال التداولي. Y ( ) تؤدي صيغة (فعيل) وظيفة تداولية تو اصلية بين المتكلم و المخاطَب في سياق الخطاب من خلال تأكيد الصفة وثباتها للوصول إلى المعنى الذي يقصده المتكلم في إطارٍ من عناصر التداولية. 
ع ()شرح شافية ابن الحاجب، تأليف: الثيخ

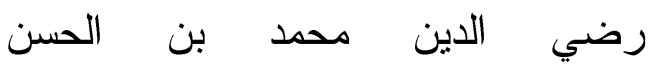

الاستراباذي (ت 71/7هـ)، دار الكتب بن

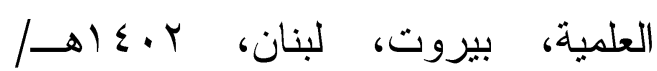

$$
.019 \lambda r
$$

10)شرح المفصل للزمخشري، تأليف: أبي البقاء يعيش بن علي بن يعيش الموصلي

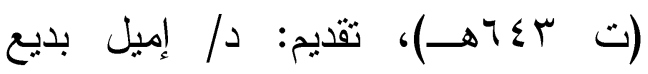

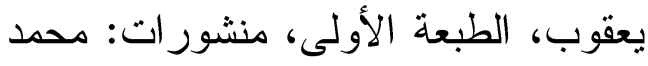

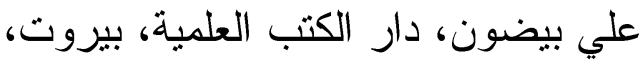
لبنان،

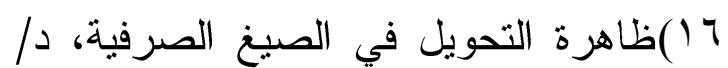
محمود سليمان ياقوت، الناشر: دار المعرفة الجامعية، الإسكندرية، 910 ام. V ا (IV والأصمعيات، صنعة: الأخفش الأصغر

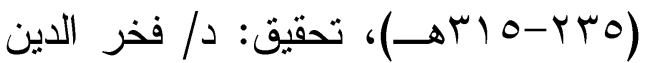
قباوة، الطبعة الأولى، دار الفكر، دمشق، دأه

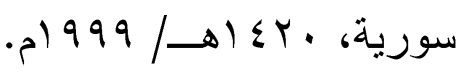
11 (1) كتاب سييويه لأبي بشر عمرو بن عثمان بن قنبر، تحقيق وشر ح: عبد السلام محمد بلابل

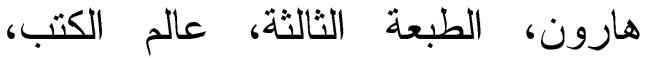

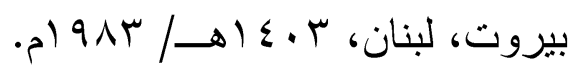
9 1))الكليات (معجم في المصطلحات و الفروق لهرون اللغوية) لأبي البقاء أيوب بن موسى لهي

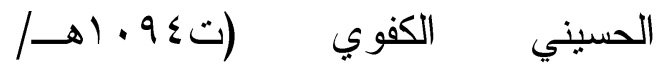

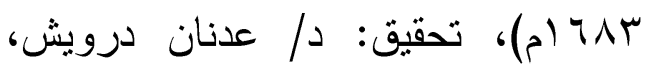
محمد المصري، الطبعة الثانية، مؤسسة الثان درونة
بلاغة النص مدخل نظري ودراسة تطبيقية، د/ جميل عبد المجيد، دار غريب لني للطباعة والنشر والتوزيع، القاهرة، .01999 م) التداولية عند العلماء العرب دراسة

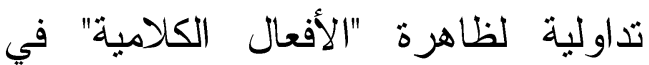

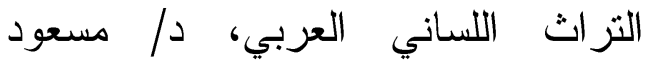
صحراوي، الطبعة الأولى، دار الطليعة دلرة للطباعة و النشر، بيروت، لبنان، يوليو . 9) التطبيق الصرفي، دم/ عبده الراجي، الطي، الطبعة الثانية، دار المعرفة الجامعية، الإسكندرية، د.ت. • ())الجملة الوصفية في النحو العربي، دم/ شعبان صلاح، دار غريب للطباعة

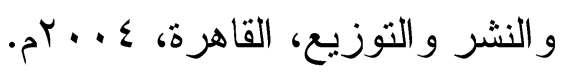
(')(الخصائص، صنعة: أبي الفتح عثمان بن جني، تحقيق: محمد علي النجار، سلسلة

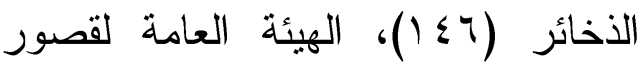

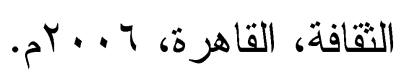
r (1)ديوان طفيل الغنوي شرح الأصمعي،

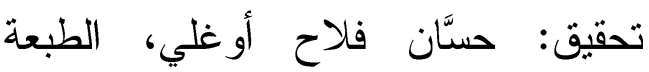

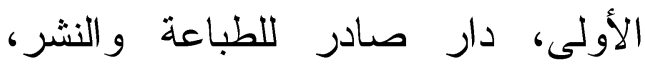

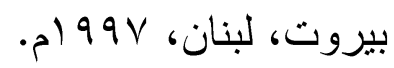
r (ا) الزيادة ومعانيها في الأبنية الصرفية في مهني ديوان الطفيل الغنوي، د/ خالد عبد الكريم بسندي، إصدارات مركز حمد الجاسر

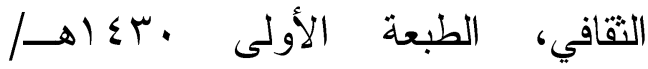
. 
TYT) المنصف شرح الإمام أبي الفتح عثمان بن

الرسالة، بيروت، لبنان، ساء اهـ|

جني لكتاب التصريف للإمام أبي عثمان . 999

المازني، تحقيق: أ/ إير اهيم مصطفى، أ/

• ץ)لسان العرب، تأليف: الإمام جمال الدين

عبد الله أمين، الطبعة الأولى، إدارة إحياء

التزاث القديم، إدارة الثقافة العامة، وزارة

أبي الفضل محمد بن مكرم ابن منظور

المعارف العمومية، ذو الحجة سVب اهــا

أغسطس 90 (م.

الأنصاري (ت | VIهـ)، تحقيق وتعليق:

عامر أحمد حيدر، مراجعة: عبد المنعم

خليل إبراهيم، الطبعة الأولى، دار الكتب

(YV همع الهوامع في شرح جمع الجوامع،

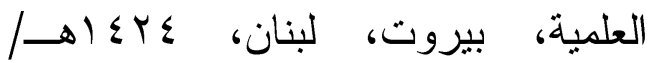

تأليف: الإمام جلال الدين عبد الرحمن بن

.

أبي بكر السيوطي (ت ا ا9هـ)، تحقيق:

(Y) اللغة العربية معناها ومبناها، دم/ تمام

أحمد شمس الدين، الطبعة الأولى،

منشورات محمد علي بيضون، دار الكتب

حسان، الطبعة الثالثة، عالم الكتب،

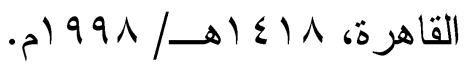

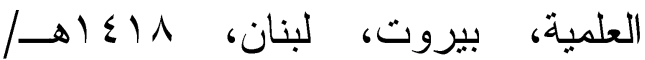

\section{ثانيًا : الدوريـات وا لمجلات العلمية المحكمة.}

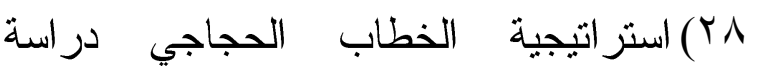
تداولية في الإرسالية الإشهارية العربية، بلقاسم دفة، مجلة المخبر، جامعة بسكرة،

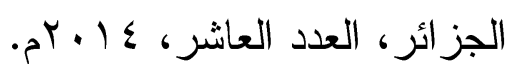

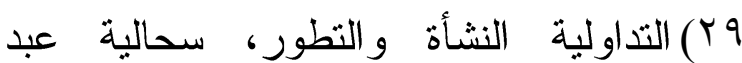

الحكيم، مجلة المخبر، جامعة بسكرة،

الجزائز، العدد الخامس، مارس 9 . . بץم.

• r الخطاب و علم اللغة التذاولي، دم/ عاطف

فضل، مؤتمر "لغة الخطاب في العصر

الحديث المشكلة و والحل"، مجمع اللغة

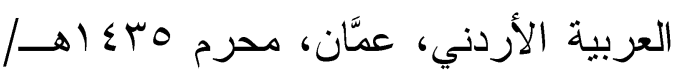

$$
\text { تشرين الثاني (نوفمبر) سا • بام. }
$$

(T) علم المخاطب بين التوجيه النحوي و التداولية، د/ عمر محمد أبو نواس، المجلة
rYr المثل السائر في أدب الكاتب و الشاعر

لضياء الدين بن الأثير ، قدمه و علق عليه: د/ أحمد الحوفي، د/ بدوي طبانه، دار نهضة مصر للطباعة و النشر، القاهرة، د.ت.

rY) المزهر في علوم اللغة وأنو اعها للعلامة عبد الرحمن جلال الدين السيوطي، الطبعة الثالثة، مكتبة دار التراث،

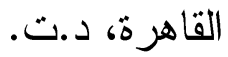

צ Y) بعاني الأبنية في العربية، دم/ فاضل صالح السامرائي، الطبعة الثانية، دار عمار للنشر والتوزيع، عمان، الأردن،

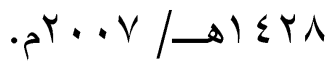

0Y) الممتع في التصريف لابن عصفور الإشبيلي، تحقيق: د/ فخر الدين قباوة، الطبعة الأولى، مكتبة لبنان ناشرون، بيزوت، لبنان، 999 (م. 


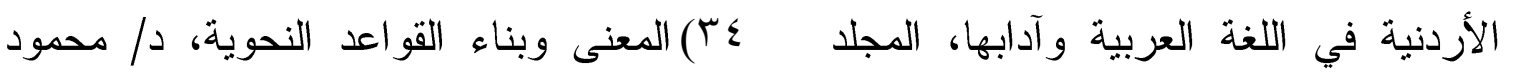
حسن الجاسم، مجلة جامعة دمشق، المجلد

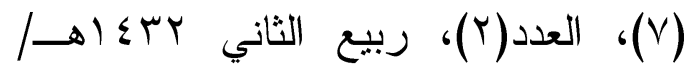

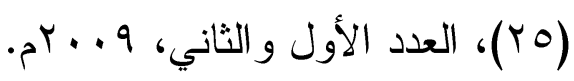

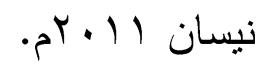

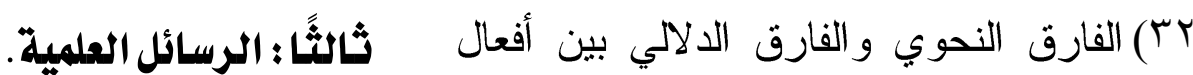

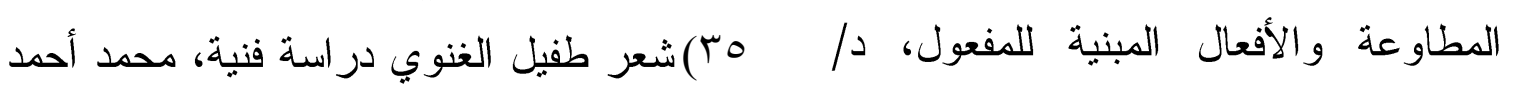

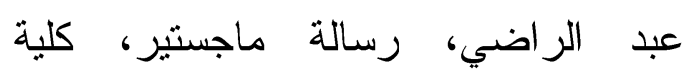
إبراهيم عوض إبراهيم حسين، مجلة

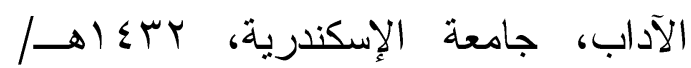

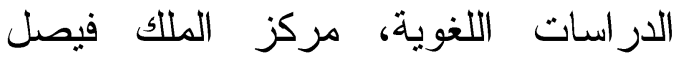
(ب)

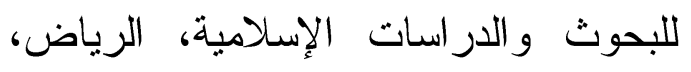

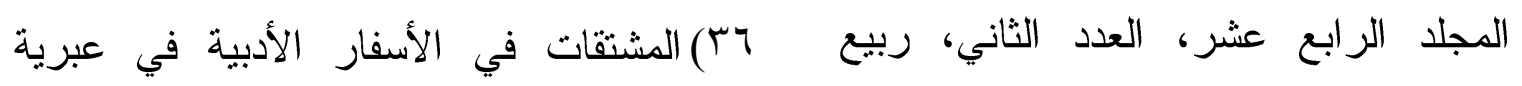

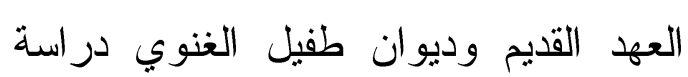

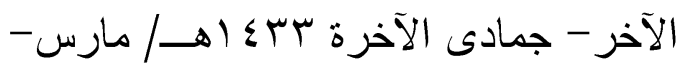
صرفية دلالية مقارنة، إيمان عبد الجواد مايو Y I ب بم.

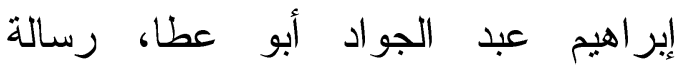

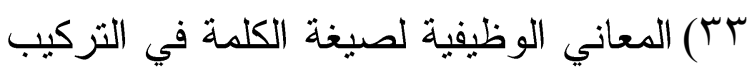
دكتور اه، كلية الآداب، جامعة الإسكندرية،

$$
\text { . }
$$

المقام في الشعر الجاهلي تتاول تداولي

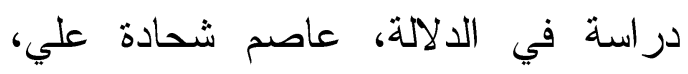

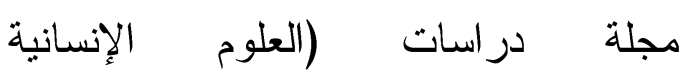

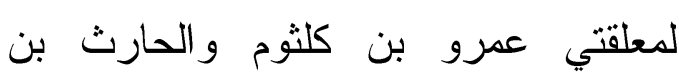

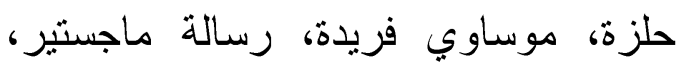

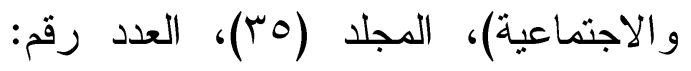

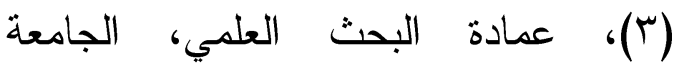

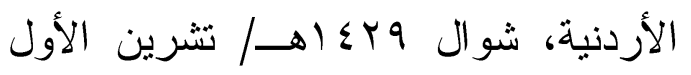

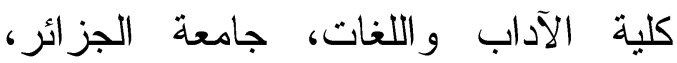

$$
\text { . } r \text {. . . . . . }
$$

